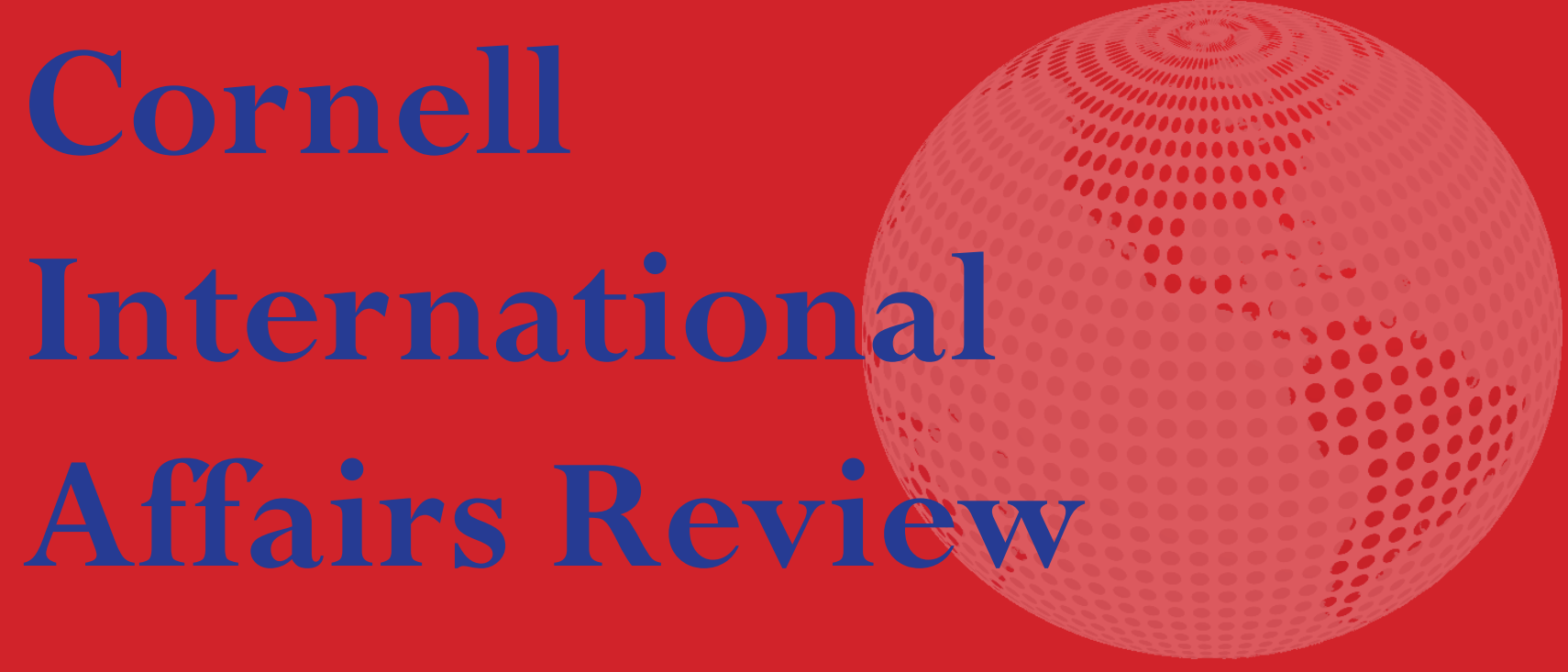

Financial Crisis and Regulatory Challenges

Michel Prada, Former Chairman of the French Securities Commission (AMF) and IOSCO Technical Commitee

In Praise of Populism

The Coming Reconstruction of Financial Regulation

Professor Elizabeth Sanders, Cornell University

The Case for America's Continued Superpower Status

Dennis Shiarev, Cornell University, 2012

Grant Gibson, Georgetown University, 2012

United States Policy and Latin America

Ambassador Luigi R. Einaudi

Gaza in Crisis

Obama's Foreign Policy in the Aftermath of Renewed Conflict

Sarah Eversman, Cornell University, 2009

Aggressive Foreign Policy, an Instrument for the Legitimization of Putin's Regime

Georgia's Case

Professor Vladimir Schlapentokh, Michigan State Univesity

Can Kosovo be a Precedent for South Ossetia and Abkhazia Recognizing Differences in Dynamics of Recognition

Anna V. Dolidze, Research Fellow, Cornell Law School

A Solution for Africa

The Coexistence of Regionalism

Anna Collins, Cornell University, 2012

Human Rights in Indonesia:

The Consequences of Discrepancies in Domestic versus International Law

Antonia Sohns, Stanford University, 2010 


\section{Cornell International Affairs Review}

\section{Faculty Advisor}

- Professor Ross Brann,

Department of Near-Eastern Studies

\section{Board of Advisors}

- Professor Peter Katzenstein, Department of Government

- Professor Isaac Kramnick, Department of Government

- Professor David Lee,

Department of Applied

Economics and Management

- Professor Nina Tannenwald, Brown University

- Professor Nicolas van de Walle, Department of Government

- Professor Hubert Zimmerman, Department of Government

- Professor Mathew Evangelista

Department of Government

- Professor Elizabeth Sanders

Department of Government

- Robert Andolina

Senior Lecturer of Finance Cornell Johnson School

\section{Executive Board}

- Luis-François de Lencquesaing,

President

- Sarah Eversman,

Vice-President

- Cecilia de Lencquesaing,

Director of Global Networking

- Dan Cahalane,

Director of Publication

- Dening Kong,

Director of Finance

- Grace MacRae,

Director of Public Relations

- Alyssa O'Connor, Secretary General

- Ryan S. Spagnolo,

Literary Director

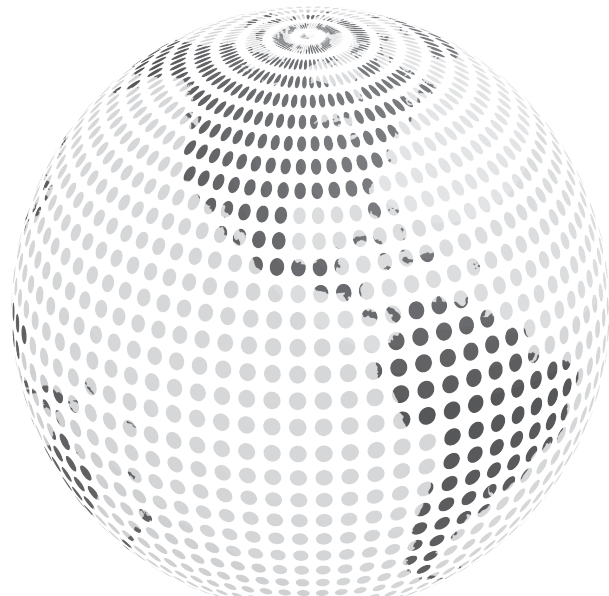

Cornell International Affairs Review, an independent student organization located at Cornell University, produced and is responsible for the content of this publication. This publication was not reviewed or approved by, nor does it necessarily express or reflect the policies or opinions of, Cornell University or its designated representatives. 


\section{President's Letter}

The CIAR is committed to providing an international, interdisciplinary and intergenerational approach to world affairs. We believe that bringing together perspectives of students from different countries and majors, with the wisdom of professors, and the vision of policy makers, contributes in an original way to the debate on foreign policy and offers tools to analyze the world in its complexities and nuances. The variety of authors published in this issue and the guests of the forums we host reflects this approach.

The financial crisis has been at the center of international concerns. This crisis of historic proportion ends an era of excess and neoliberal ideology. Solving this global mess will require restoring values and responsibility. This crisis also shows that a global world needs global rules. Cooperation between nations to avoid a recession and to prepare the post-crisis regulatory framework is necessary. The success of the G20 meeting the 2 nd of April has been a step in the right direction. This CIAR issue focuses on the challenges for a new regulatory framework. It is important to curtail excessive risk-taking and irresponsible behavior by re-engineering convergent regulation at both the national and international levels. We need 'smart regulation' with a balance between allowing innovation in financial products and providing reasonable investor protection. Michel Prada, as Chairman of the French securities regulator and head of the IOSCO Technical Committee, was at the front seat in dealing with the crisis. He brings here his unique perspective on the topic and outlines his vision for tomorrow's global regulatory framework. Professor Sanders writes on the changes we can expect in US financial regulations, given the role of Congress, of the executive branch and of popular pressures.

This CIAR issue also addresses other challenges the world is facing today. Ambassador Einaudi, a high ranking US diplomat, proposes his vision for the US relations with a changing Latin America. The reemergence of Russia as an important player and the war in Georgia require an analysis of its foreign policy. Professor Shlapentokh and the Georgian activist Anna Dolidze examine this. Finally, other world issues are explored by Cornell students.

In addition to our publication, the CIAR organizes many events on campus. A series of working breakfasts or lunches with faculty and visiting policymakers, our gala dinners, and our forums and panel discussions, are occasions to promote interest in world affairs. This semester we hosted among others Princeton Professor Frank von Hippel, who spoke on nuclear proliferation issues. These events illustrate our objective of mobilizing resources across colleges and disciplines to help us understand the multiple dimensions of a topic. We also animate weekly discussion groups among undergraduates to further explore world affairs.

It is my hope that the work we have done in founding and perfecting this think tank and publication has raised the intellectual vibrancy of our campus and proven that students are capable of addressing complex foreign policy issues. It shows that students remain engaged with the world and that we are eager to debate and interact with professors. As I prepare to graduate, I leave CIAR confident that it will continue to be a center of reflection on campus and grateful to all those who have participated in this adventure.

The world we live in is fluid and challenging. It is our responsibility as students and as citizens to engage in the foreign affairs debate and to attempt to provide fresh perspectives to make the $21 \mathrm{st}$ century a sustainable century for peace. 


\section{Editorial Letter}

The volume II, issue 2 of the Cornell International Affairs Review journal brings forth articles on several topics concerning the events shaping our globe currently. The far-reaching consequences of the financial crisis has raised concerns worldwide. This issue examines the different perspectives on the global financial crisis with articles from Michel Prada and Cornell government professor Elizabeth Sanders. We extend our sincere appreciation to both professionals on sharing with us their expertise on the challenges of government regulation of the free market economy as well as the implications of reforming the existing economic systems to re-stimulate growth. Professional Anna Dolidze questions whether Kosovo declaring its independence as a free nation could be an appropriate guide or model for South Ossetia seceding from Georgia, the region most directly affected by the Russian-Georgian war in the summer of 2008. We equally appreciate her contribution as well. Professor Shlapentokh writes on Russian foreign policy and the internal legitimization process of an instable political regime which leads to an aggressive foreign policy.

Additionally, we had both the honor and the pleasure of meeting Ambassador Luigi R. Einuadi, the former Secretary General of the Organization of American States. Speaking at the conference"Europa in America: A 20th Anniversary Celebration of the Luigi Einaudi Chair in European and International Studies at Cornell" hosted by the Institute for European Studies, Einaudi spoke in commemoration of his grandfather, a President of the Italian Republic, as well as his experience working with the Organization of American States. He shared with the board of CIAR his perspective for the United States foreign policy towards Latin America, which are published here.

Student contributors equally tackled current international affairs topics with clear academic insight and passion. Dennis Shiraev visits the image of the American superpower in light of the end of the Bush administration and the beginning of the Obama administration, reflecting not only on military and economic hard power but also soft power in culturally influencing the rest of the world despite the rise of Brazil, Russia, India and China (BRIC countries). Anna Collins examines regional economic integration for Africa, arguing that the European Union does not provide an adequate model but rather African nations must use their own macroeconomic policies and free trading agreements to replicate a similar type of common market among its neighboring countries. Stanford contributor Antonia Sohns elucidates the discrepancies in international law versus domestic Indonesian law in a human rights case of Freeport McMoran, highlighting the often incompatible correlation between the two bodies of legislation. Sarah Eversman analyzes the humanitarian crisis in the Gaza as the truce between Hamas and the Israeli government degenerated again into violent and repressive warfare and the policies of foreign nations in mitigating and potentially resolving the fight.

As we are both graduating this year, this will be our last issue of the Cornell International Affairs Review. We want to extend our sincere and utter gratitude to the members of the organization, especially the editors and writers, for their contributions to the journal. We hope that we may continue to receive as many excellent submissions varying in a wide range of international topics, from politics and the economy to culture, from Southeast Asia to Latin America. May we be able to carry our mission ever farther into the future. Thank you all for your time, hard work, patience and energy.

Sarah Eversman

Cornell University

Arts and Sciences, 2009

Vice President

Cornell International Affairs Review

\section{Ryan Spagnolo}

Cornell University

Arts and Sciences, 2009

Literary Director

Cornell International Affairs Review 


\section{Contents}

Financial Crisis and Regulatory Challenges

Michel Prada, Former Chairman of the French Securities Commission

(AMF) and IOSCO Technical Commitee

\section{In Praise of Populism}

The Coming Reconstruction of Financial Regulation

Professor Elizabeth Sanders, Cornell University

\section{The Case for America's Continued Superpower Status}

Dennis Shiarev, Cornell University, 2012

Grant Gibson, Georgetown University, 2012

\section{United States Policy and Latin America}

Ambassador Einaudi, former Secretary General of the Organization of American States

\section{Gaza in Crisis}

Obama's Foreign Policy in the Aftermath of Renewed Conflict

Sarah Eversman, Cornell University, 2009

\section{Aggressive Foreign Policy, an Instrument for the}

Legitimization of Putin's Regime:

Georgia's Case

Professor Vladimir Schlapentokh, Michigan State Univesity

Can Kosovo be a Precedent for South Ossetia and Abkhazia

Recognizing Differences in Dynamics of Recognition

Anna V. Dolidze, Research Fellow, Cornell Law School

\section{A Solution for Africa}

The Coexistence of Regionalism

Anna Collins, Cornell University, 2012

The Consequences of Discrepancies in Domestic versus 


\title{
Financial Crisis and Regulatory Challenges
}

\author{
Michel Prada \\ Former Chairman of the French Securities \\ Commission, the Autorité des Marchés Financiers \\ (2003-08) and of IOSCO Technical Committee
}

A number of reports have established a diagnosis of the financial crisis. The first was produced by the Financial Stability Forum, in April 2008 and was the basis for the preparation of the first $G 20$ meetings in 2008. The International Monetary Fund (IMF) and the $G 30$ produced updated analysis in 2008 and 2009. More recently, the Larosière Group, although mainly focused on E.U. issues, also addressed global concerns, as well as the Adair Turner report which presented the new regulatory strategy of the UK Financial Services Authority (FSA). The main features of this unprecedented financial crisis are linked to immense and growing global imbalances between the Asian and US economies which provided the world with abundant liquidity, low interest rates together with low inflation (due to low wages in emerging countries) and a geographic mismatch between savings and investment needs and opportunities.

Investors' search for yield coexisted with low risk aversion and gave way to an unprecedented development of credit, fostered by securitisation and financial innovation. Credit discipline was lost from sight and a credit bubble developed between 2002-2007, mainly in the real estate sector but also in the credit card and leveraged buyout (LBO) activities. The so-called originate to distribute model (OTD) flourished in a grey area (don't need quotation marks) of unregulated or under regulated activities and markets (the OTC market, where professionals operate on a contractual basis). Externalisation of risk allowed banks to appear resilient: their equity ratios seemed adequate and even comfortable, since the risks were transferred to investors such as hedge funds, pension funds and clients of the asset management industry, through deconsolidated devices (the conduits and sivs) which operated as shadow banks and funded structured products by issuing commercial paper. Derivatives and structured products (RMBS, ABS, CDOs, to name a few) developed rapidly, the assumption being that risk dissemination and insurance, based on complex products (Credit Default Swaps, for example) and specific protection schemes (the monolines), was the new paradigm of the financing of economic growth in a globalised world. Global leverage lost control, as well as liquidity, operational and counterparty risks. A monetary policy that aimed to control inflation caused interest rates to go up, leading over-indebted households to start defaulting in summer 2007. The price of structured products went down and credit rating agencies suddenly downgraded them. Holders, including hedge funds, started selling massively due to covenants and redemptions. The crisis started in the asset management field and might have triggered a panic in the public had banks not repatriated the risks in their books, either to comply with liquidity commitments to their "sivs" and "conduits" or to protect their commercial reputation, as many of them where involved in the production and distribution of structured products and also in the management of their asset management subsidiaries. It consequently appeared that their capital was not sufficient to face the required provisioning, that there was no active market for these structured products and that their valuation was uncertain. Confidence in the banking system was affected, while banks started hoarding liquidity to face their obligations.

These factors produced a liquidity 
crisis in the banking system and the freezing of interbank markets, leading governments and central bankers to intervene from summer 2007 to summer 2008). The demise of Lehman Brothers in September 2008 gave way to a second phase of the crisis, which developed into a solvency crisis affecting a number of banks and forcing governments to play the role of lender of last resort, bailing the banks out through capital injection, guarantees and even nationalisation. Thus started the third stage of the crisis, the transmission to the "real" economy through the credit crunch which triggered the re-launch programs in the US, EU and elsewhere.

In parallel with governments' efforts to consolidate the banking system in order to fight recession and to restore confidence, this global crisis raises three sets of regulatory issues which are being considered by the $G$ 20. The first set of issues concerns the need to improve macroeconomic and macroprudential management at the global and, possibly, regional level, in order to better identify global imbalances and take the necessary measures in a more coordinated way. This is both a political and technical question. The $\mathrm{G} 7$ approach is no longer relevant in a world where major emerging economies play a significant role and have to be part of the global architecture of macroeconomic monitoring. Similarly, the role and capacity of the IMF has to be reconsidered: the IMF should recover a capacity to bring together all the relevant information in order to foresee possible imbalances and to trigger collective and coordinated reactions; it should have the necessary authority to monitor national policies and implementation of international standards and orientations; it should have enhanced financial capacity to provide support to emerging countries affected by imbalances or recession.

A second set of issues is related to the necessary enlargement of the scope and content of regulation. The word "regulation" is here understood in a broad sense which

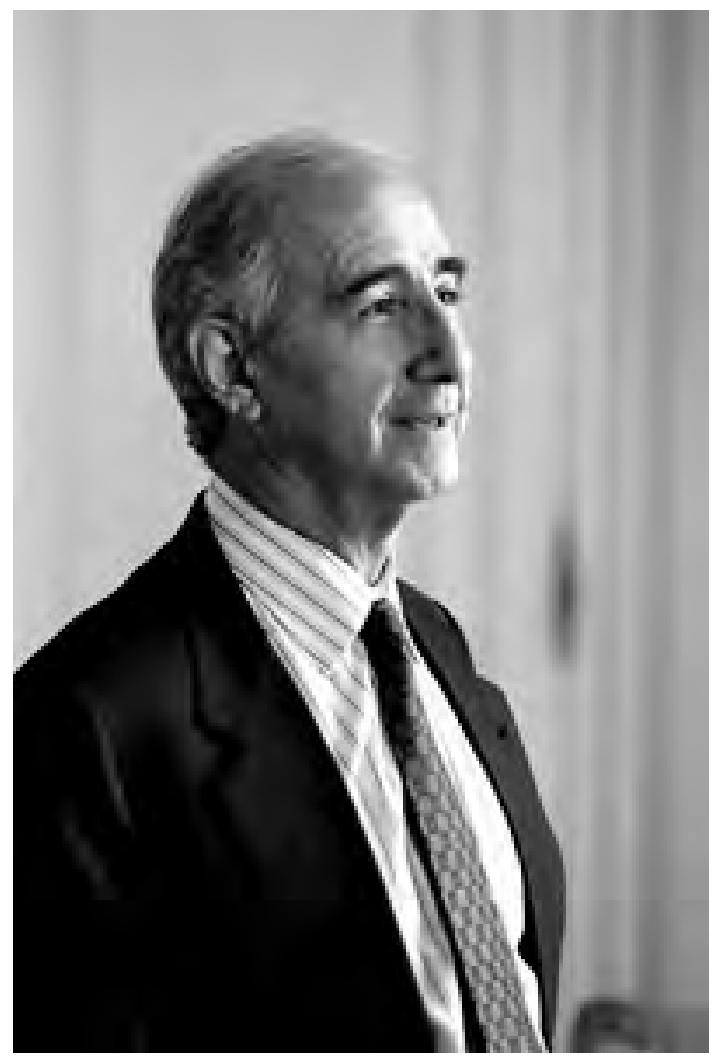

MIchel Prada, former Chairman of the AMR and IOSCO Techinical Commitee

encompasses all means aiming to monitor a complex system, including not only ruling but also supervision, reporting, self regulation, best practices, and so forth. One of the specificities of this crisis is due to the fact that the triggering events took place outside the classical regulation of intermediaries and markets: unregulated, or poorly regulated, entities, products and markets played a major role.

There is a need to improve banking supervision in order to master leverage, which is key to sound intermediation. Among the manyquestionsunderconsideration, threenew topics have been identified: liquidity risk and maturity mismatch should be more thoroughly taken into consideration in the determination of capital requirements; deconsolidation has to be rigorously determined in order to put an end to the practice of flawed and ambiguous securitisation; procyclicality of capital adequacy requirements has to be addressed 
through the possibility of "through the cycle" dynamic management of reserves.

There is a need to enlarge market supervision which should encompass unregulated entities, and Over the Counter (OTC) markets, and to strengthen market infrastructures (namelyclearingand settlement of derivatives). In that domain, transparency is a central concern. The OTD model has to be repaired, starting with origination of credit, transparency of arrangement, rating and distribution. Along the chain of securitisation, transparency together with risk management and prevention of conflict of interests have to be restored.

Accounting standards are also essential in this new model. While accounting should not be instrumentalised in order to solve managerial or prudential concerns, the standards should be relevant to firms' business models: hence the need to differentiate more clearly the trading book which should be accounted for at market value, the "available for sale" items, which should be at fair value, and the banking book, which should remain at cost, since the items are held to maturity.

Finally, a third set of issues concerns the global architecture of regulation. In that domain, much has been achieved since a decade or so. A number of international institutions have improved their visibility, enlarged their standards, and enhanced the cooperation between their members. The Basle Committee is the leading organisation for prudential standards applicable to banks. Significant progress has been made through the adoption of Basle 2, although new improvements are under consideration. The International Association of Insurance Supervisors (IAIS) is the organisation for insurance and plays a major role in the field of prudential standards (Solvency 2) and conduct of business rules. The International Organisation of Securities Commissions (IOSCO) is the global organisation for securities regulation and serves as a good example of the progress made since over a decade. In 1998 , it unanimously adopted a common set of

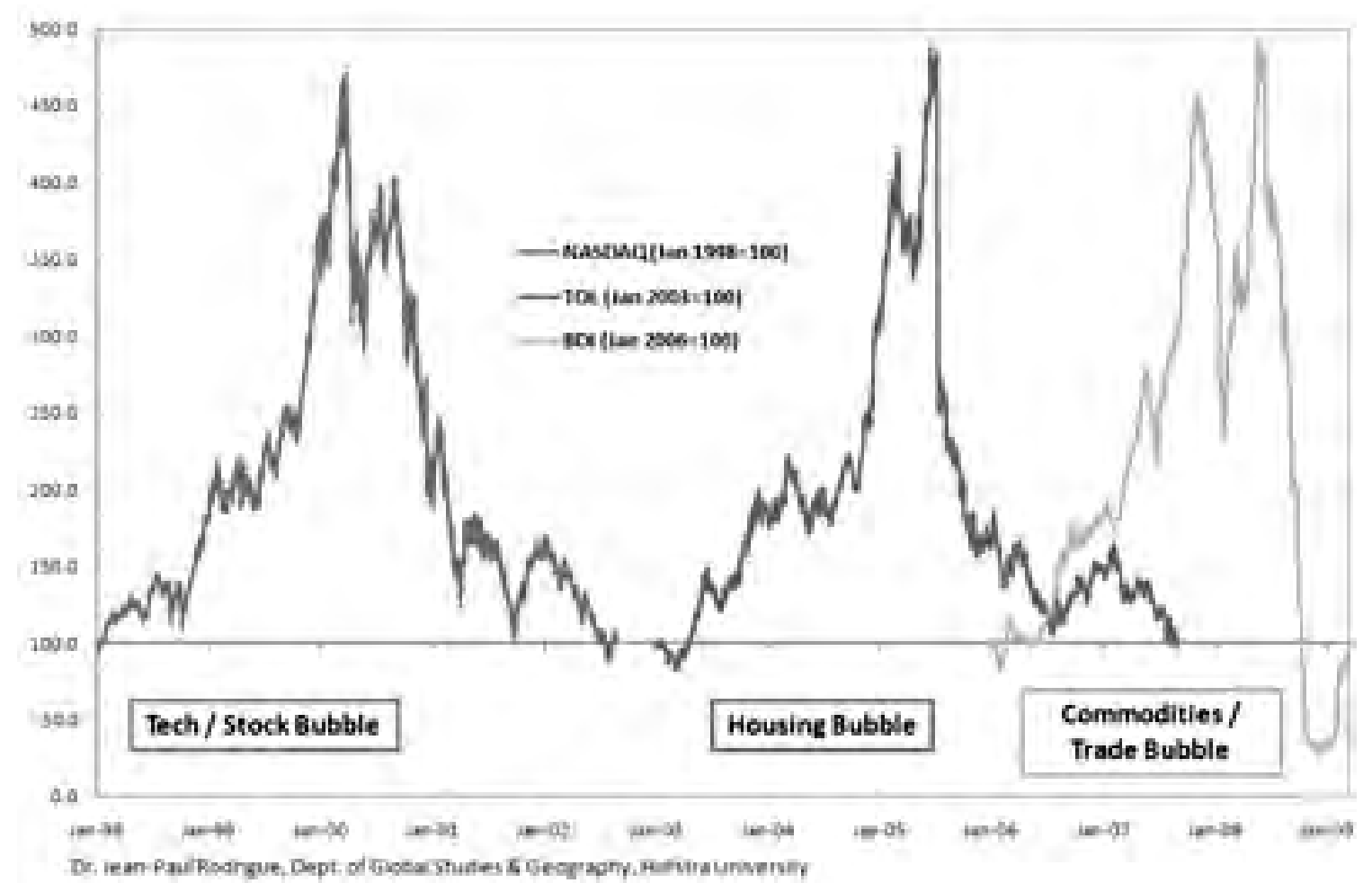

The three market bubbles of the past decade that were in part responsible for the Great Depression-like crash that the economy experienced in 2008 
objectives and principles. In 2000, it endorsed the39Inter-AgencyStanding Committee(IASC) core standards for accounting, which paved the way to the creation of the International Financial Reporting Standards (IFRS) and their adoption throughout the world, beginning in Europe. In the aftermath of the Internet bubble and early millennium scandals, it took a series of initiatives to combat financial fraud (the signing of a multilateral memorandum of understanding to improve international cooperation in enforcement, new standards for audit and financial analysis, a first code of conduct for rating agencies, completed in 2008 to address the issue of structured products).

These three major organisations have learnt to work together within the Joint Forum on issues of a cross sectoral nature, such as conduct of business rules, securitisation or risk management.

In the aftermath of the 1997 Asian crisis, the G7 established the Financial Stability Forum (FSF), which gathers together international standard setters, ministries of Finance, Central Banks, International Financial Institutions (the IFIs, such as the IMF, the World Bank, the Bank for International Settlements, the Organisation for Economic Co-operation and Development (OECD), and representatives of a few major financial centers. The FSF plays a useful role as a high level secretariat for the G7 and as a global coordinator of all the major institutions involved in standard setting, monitoring and enforcement in the macro prudential and micro financial fields.

One could legitimately question the efficiency of all these efforts, which have been unable to prevent the crisis.

Firstly, although globalisation has thrived for 20 years and regulators have made significant progress in the field of cooperation and standardisation, nationalistic behaviors are still predominant. Competition between marketplaces sometimes leads to diverging regulation and regulatory arbitrage. Ideology also plays an important role and diverging views prevent from addressing relevant

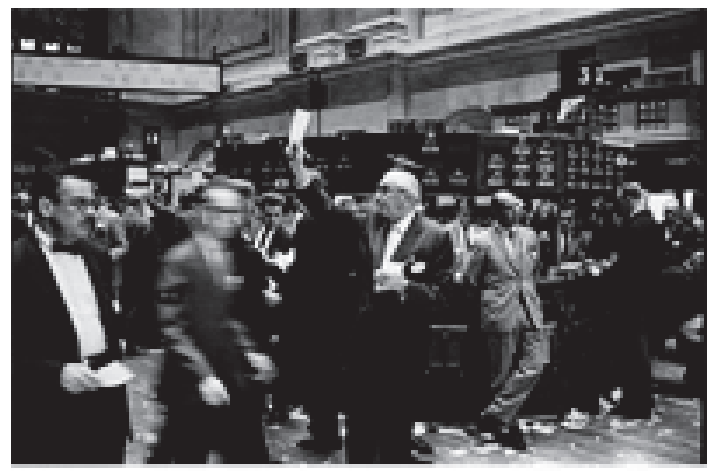

The New York Stock Exchange

issues- that was obviously the case with regards to securitisation and risk transfer which was considered by major regulators as the new paradigm of $21^{\text {st }}$-century finance. It was also the case with regard to the so-called "light touch regulation" which considered that market players were smart enough to self regulate and manage risk, while overregulation would have perverse effects and would increase costs. Trillions of losses later, it appears that there is no common measure between the cost of regulation (tens of millions...) and the consequences of deregulation. Another flaw in the system is due to the existence of unregulated or uncooperative jurisdictions which originate loopholes in cooperative arrangements, ruin the efficiency of enforcement and encourage misbehaviour of market participants and anticompetitive maneuvers. This is not acceptable in a globalised economy. While legal innovation and even tax competition may be acceptable under certain circumstances, the organisation of opacity is fundamentally detrimental to the normal functioning of a sound market. Uncooperative jurisdictions have to join the regulatory community and to behave along the principles of international cooperation. If they do not, they should be banned from doing business with the rest of the world and market participants which use them should be severely penalised.

It is now time to foster international cooperation and to strengthen the global architecture of regulation. There is no need to start from scratch and reinvent the wheel 
because the components of a sound system already exist. Political will is of the essence.

A crisis, however serious it may be, is always an opportunity to rebound and progress. This financial crisis should lead to addressing a number of technical issues in order to make the financial system more robust, more efficient and better adapted to the challenges of globalisation. Beyond technicalities, this financial crisis is also an opportunity to remind market participants that ethical principles and behaviour should be at the center of a sound financial system. Never in the past has greed been observed to such a level of provocation, with a serious risk of popular reactions. Never in the past have conflicts of interests been used in such a cynical way. Never in the past have such huge scams been observed which ruin the confidence of the public and destabilise the credibility of supervisors.

There is an urgent need to repair the system. This neitherimplies over-regulation nor over reaction which might have unexpected consequences. This deserves determined action by governments, regulators and market participant organisations, in a coordinated way and on a global basis. This is the only way to restore confidence, which is a fundamental precondition for an efficient market economy, having in mind the fact that market economy, like democracy, is the best of all systems or, at least, the better system.

Photo s Courtesy of:

"Michel Prada." Hedge Funds Watch. 4 April 2009.<http://hedgefundswatch.blogspot.com/2007/04/focus-sur-michel-prada-patron-du.html>

U.S. Department of Interior. "New York Stock Exchange." . 2 April 2009. < http://en.wikipedia.org/wiki/File:NY_stock_exchange_traders_floor_LC-U910548-6.jpg>

"Economic Graphs." Hofstra University. 4 April 2009.<people.hofstra.edu/Jean-paul_Rodrigue/blogs.html> 


\title{
In Praise of Populism \\ The Coming Reconstruction of Financial Regulation
}

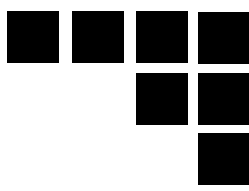

\author{
Professor Elizabeth Sanders \\ Professor of Government, Cornell University
}

Newspaper and Television commentaries in the United States and Europe abound with references to "outbursts of populism" in United States as a stereotypically American response to economic crisis. ${ }^{1}$ Their story lines trivialize historic Populism in the U.S., both its substance and its contribution to financial regulation. American Agrarian movements arose in response to grievances rooted in pathologies of mature, weakly regulated capitalism. The agrarians had real grievances linked to rigidities of the gold standard and bank control of note issue, monopoly control of longdistance transportation and crop storage, the use of the growing power of large firms to repress labor, and a rising cost of living due to growing monopolization and high tariffs. Most of the policy solutions demanded by late $19^{\text {th }}$ century populism and its progressive era legatees were enacted in some form in the two spurts of regulation during the early $20^{\text {th }}$ century (the progressive era and New Deal). There are indeed some commonalities between public criticism of capitalist greed in those periods and the present; but scorn for "populist outbursts" against the risks taken by greedy financiers who made billions while bringing financial ruin to the global economy distracts our attention from the destructive folly of those financial actors, and presumes that public outrage is unjustified and counter-productive.

In fact, it is neither. That such a small number of actors could wreck such havoc on the world is surely a cause for outrage among reasonable people around the globe. Recognition of error is essential for human learning and the evolution of institutions. It would be quite peculiar, and disturbing, if there were no wave of criticism in the face of such unethical and damaging conduct. No American reform surge has occurred in absence of such public outrage. It was public offense over corporate malfeasance that gave us the 1887 Interstate Commerce Act, the 1890 Sherman Antitrust Act, the 1894 income tax law (and the 1913 Constitutional amendment needed to overcome Supreme Court objections), the 1913 Federal Reserve Act, the Child Labor Acts, the 1933-34 laws taking the dollar off gold, the 1934 Reciprocal Trade Agreements Act (which moved the nation away from the protectionist disaster of the Hawley-Smoot Tariff and toward trade expansion), the 1933 and 1934 Securities Acts, the 1933 Glass-Steagall Banking Act, the creation of the Federal Deposit Insurance Corporation in 1933, the 1938 Fair Labor Standards Act, and many other laws that served this country, and the world economic system quite well for many decades.

The troubles the United States and the rest of the world are now experiencing are the consequence of the repeal or lax enforcement of much of that "populist" legislation, or (in the case of the more exotic financial instruments now gone toxic) the deliberate policy choice NOT to regulate those new products, while United States policy makers were firmly in the grip of the neoliberal ideology that triumphed in American politics in $1980 .^{2}$ At the opposite pole from "populist outrage, " Americans were lulled into quiescence in the Clinton years by the public officials and expert economists who assured them that these esoteric instruments, and continuing deregulation of finance and securitization, would lead to indefinitely expanding prosperity.

Now that the United States has once again learned the painful lessons that the 1930 s generation learned, and on the basis of 
which, with expressions of outrage from the president on down, the U.S. then constructed a well regulated financial system that was a wonder of the democratic world, a resurgence of the "populist outrage" that led to that legislation is both normal and useful to the current reform effort. And so long as Congress and the president appear to be seriously working on the construction of a new edifice of regulation to prevent future crises of this magnitude, American outrage will likely be more restrained than that of the French and British protests.

One of the misconceptions of journalists engaged in commentary about "populist outrage" is that historical American Populism of the late $19^{\text {th }}$ century was intolerant and focused on scapegoats. Nothing could be farther from the truth. The Farmers' Alliance was, for its time, remarkably inclusive in forging an alliance of white and black farmers, supporting black suffrage (and women's suffrage, as well), endorsing the demands of the labor movement, and promoting political and economic equality within a capitalist democracy. They were confident that antitrust laws, regulation of large firms, more rights for labor, and a publicly controlled national currency not tied to gold alone and expanding to keep pace with commerce and population growth would expand the nation's prosperity. And they were right, though regulatory learning and adaptation took place in the rough and non-linear fashion that is

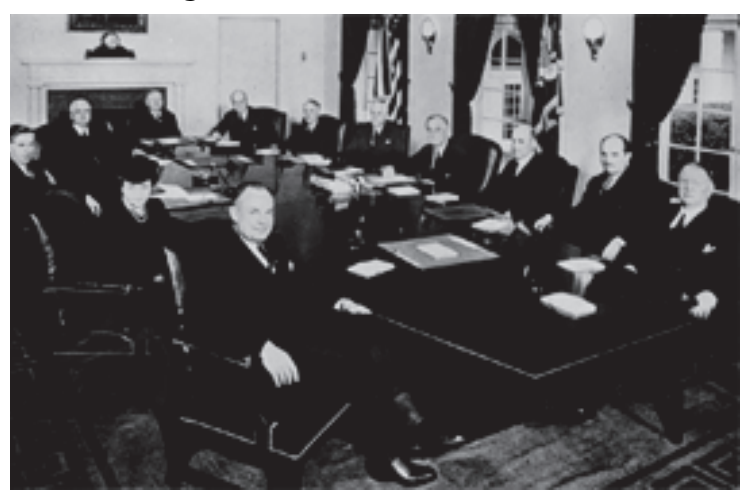

Franklin Delano Roosevelt's progressive cabinet, which was responsible in part for the financial regulations of the early 1930's. characteristic of all human experimentation with institutional rules.

As the $\mathrm{G}-20$ countries press the United States to reform the (de-)regulatory system that permitted the financial practices that brought down the global economy, it is well to give the Populists (and Progressives, and New Dealers) their due, and to cast a curious eye on earlier institutional learning.

\section{The Past as Prelude}

If there is to be a new surge of regulation, a "new New Deal" as it were, what might be the contours of the new system, and the pattern of politics that produces it? On the basis of past episodes of severe recession and regulatory creativity, and with governmental separation of powers and the two-party system held constant, the following predictions can be made: (1) The United States will construct its new financial regulatory system as a national effort, despite the president's endorsement of the need for international coordination of financial rules at the G-20 meetings; (2) even though Treasury Secretary Timothy Geithner has struck first with a rough template for a new system of national financial rules, ${ }^{3}$ Congress will have as much, or more, to say about its shape; (3) the legislative recommendations will be embodied in more specific and punitive bills (the House version more restrictive than the Senate bill) than proposals by the executive branch; and (4) party and region (which overlap significantly) will channel "populist rage" in very different ways.

But such an intensely national regulatory process, and the American president's refusal to promise any real enforcement power to the new international Financial Stability Board conceived at the G-20 meeting ${ }^{4}$ need not distress the European and other officials so unhappy at what lax U.S. regulation has done to the world economy. If there is indeed a new surge of American financial populism, it might provide the tough rules the international community demands for American firms, and even a model to which 
others might subscribe.

\section{Regulatory Nationalism}

In the early summer of 1933, Britain and Europe waited anxiously for the president's emissary, Raymond Moley, to arrive by ship for an international conference to coordinate western responses to the depression, especially monetary strategies. They were severely disappointed. Franklin Roosevelt had been battered by domestic populists into taking the U.S. off the gold standard and allowing the dollar to fall precipitously in its relation to the pound, a boon to commodity prices and U.S. exports. The president would not agree to stabilize the dollar in a narrow range around \$4/pound sterling, as the British demanded. Roosevelt's sole concern was the domestic economy and congressional pressure to take far more drastic action than his own Tory temperament could allow. ${ }^{5}$ As the World Monetary and Economic Conference in London began, the dollar had slid to \$4.43/ pound, despite the desperate protestations of Roosevelt's international financial advisor, Paul Warburg, and his Budget Director Lewis Douglas, who famously described going off gold as "the end of western civilization."6

For Roosevelt, it was necessary to reflate the domestic economy and subdue the congressional agrarians. While the Europeans pressed for monetary stabilization, the goal of the conference in the president's mind was to preserve "his freedom to act on the domestic scene" and "to raise the [commodity] price level." The international conference should thus "go along and work in our New Deal direction 'of debtor relief, price raising, and the increase of purchasing power if there was to be anything' to cooperate about." ${ }^{7}$

The G-20 meeting of April 1-2, 2009, ended much more amicably and optimistically, with verbal agreement on cooperation for extensive reconstruction of financial regulation, as well as an expansion of credit through the IMF, aid to poor countries, and a pledge to resist trade protection.
President Obama is much more attuned to global responsibilities than the pre-war Franklin Roosevelt (or G.W. Bush throughout his administration). However, it is success in domestic policy that assures reelection, and diplomacy thrives mostly in the last two years of an eight-year presidency. International coordination thus cedes priority in the early years of an administration to immediate political needs. And the United States is not alone in putting national interests above international demands, in the 1930 s or 2000 s. ${ }^{8}$

Of course, there is greater interest in Europe than in the U.S. for establishing some degree of international control of financial practices, as the only way to reign in an American system gone mad. The U.S. failure to regulate its financial products infected the rest of the world, and if the U.S. is not willing to regulate itself, others will attempt to establish supranational regulatory authority. ${ }^{9}$

\section{Institutional Competition over Economic Regulation}

But inaction on the part of the United States is extremely unlikely. Though Secretary Geithner has made very general recent proposals for restoring and modernizing national financial regulation, the president has observed that he expects Congress to be deeply involved. Indeed, that has always been the case. At the beginning of national business regulation in the late $1880 \mathrm{~s}$, Congress took the lead and the president was almost invisible. In the next two regulatory surges, the president was much more involved, but Congress, always mindful of its Constitutional duty to regulate interstate commerce, and far closer than the president to the economic distress of less advantaged constituents, was a strong contender in the shaping of regulatory law. In many cases of Progressive Era and New Deal regulation-for example, in railroad, antitrust, labor, commodity futures, trade practices, deposit insurance, the separation of investment from commercial banking, and the establishment of federal regulation over 
securities trading, Congress took the lead and the president struggled to influence the legislative process. ${ }^{10}$

By the time President Wilson took office in 1913, Congress was already at work on creation of a federal banking system (the Federal Reserve); by Roosevelt's inauguration in 1933, congressional Democrats were enmeshed in drafting bills for federal deposit insurance (despite the President's opposition), ${ }^{11}$ and made the United States the first country to enact such a system, decades ahead of other democracies. Congress-acting through the typical Progressive and New Deal era reform coalitions of agrarian Democrats and Midwestern progressive Republicans-had attempted to regulate securities trading in 1914, but President Wilson's opposition delayed such government supervision until $1933{ }^{12}$ the House had, by that point, been investigating securities trading and the need for federal control of the stock exchanges for almost a year under the guidance of committee counsel, Ferdinand Pecora.

In 2006, as in 1930, Democratic victories in congressional elections preceded the election of a Democratic president and that, along with its active institutional tradition in interstate commerce regulation, gave the legislature a head start on new legislation. There is no reason to think this institutional activism has faded. The fact that Congress has taken its time with investigations of "what went wrong" and given priority to stimulus packages and alleviation of immediate distress through attention to the housing mortgage crisis, small business credit, and credit card debt alleviation ${ }^{13}$ should not be interpreted as an indication of legislative disinterest in permanent legal remedies to prevent recurrence of the exposed financial wrongdoing.

The House of Representatives usually takes the lead on regulatory law, by virtue of being closer to its (generally) smaller constituencies, and standing for more frequent election, as well as the Constitutional requirement that tax legislation begin in the House. Further, House members serve on fewer major committees, and thus specialize to a greater extent than Senators. A broad generalization, aided by the fact that Senators were only popularly elected after 1913, overrepresent small and conservative states west of the Mississippi, and usually have much more expensive campaigns to fund than Representatives, is that regulatory legislation in the House will be stricter than in the Senate.

It is thus Representative Barney Frank of Massachusetts, Chair of the House Financial Services Committee, who will play the lead role in producing new financial regulation, in a committee with a history of populist regulatory tendencies. ${ }^{14}$ And Frank himself might be described as a modern day Populist, never enthusiastic about deregulation, close to organized labor, sympathetic to debtors, and less dependent on the finance industry for campaign contributions than the President, his Chief of Staff, or the finance industry's favorite beneficiary, Senator Chris Dodd of Connecticut, chair of the Senate Banking Committee. $^{15}$

Frank is intent on rebuilding and modernizing financial regulation, particularly extending federal control over "Hedge funds, private equity funds, investment banks anything that's not a bank" under existing regulations. His committee will also seek federal supervision over the securitization of financial products, and executive pay practices, the latter in order to remove perverse management incentives to take undue risk. ${ }^{16}$ These concerns line up closely with the regulatory goals of the G-20, particularly those of the strongest regulation advocates, Angela Merkel of Germany and Nicolas Sarkozy of France. ${ }^{17}$ The House committee's bill will no doubt get watered down in the more conservative Senate but the final congressional bill to regulate the finance industry may be expected to exceed in toughness and specificity the proposals of the executive branch, if history is a reliable guide. ${ }^{18}$ House populists, then, should be the 
natural allies of Europeans seeking stronger U.S. financial regulation.

\section{Party, Region, and Triangulating Presidents}

Populism, historically, emerged from the agricultural and mining regions of the South, Midwest, and Mountain states in the 1890s. A century later, in the midst of recession, an outburst of financial populism put a scare into bankers and the conservative Federal Reserve Board. ${ }^{19}$ In the difficult economy of the late 1970s and early 1980s, as well as the recession of the early 1990s, (the last episode of full-fledged populist challenge before the present era), some residue of the old populist era geopolitics was still present in the willingness of farm districts and states to challenge bankers (both private and central). But in congressional efforts to wring lower interest rates, more transparency, and democratic responsiveness from the Federal Reserve Board, agrarian regions were joined in the 1980s and early 1990s by Democratic Congress members from urban constituencies (mostly northern) that were experiencing relatively high unemployment and low median income.

Though little came of the hundreds of Fed-curbing bills introduced in the House and Senate, the populist agitation was serious enough that President Clinton used it (in classic"good cop, bad cop"fashion) to pressure the Fed to loosen up on monetary policy. One might argue, then, that congressional populism was instrumental in persuading Fed Chair Alan Greenspan to ease off the brakes on money and credit creation-a development that was a major cause of the unprecedented economic growth of the Clinton years. ${ }^{20}$

But in Clinton's second term, with a rambunctious Republican majority in the House and Senate, and the president in full "triangulation" mode, populism gave way to a neoliberal juggernaut led by the president himself. The 1933 Glass-Steagall Act separating investment and deposit banking was repealed, with strong presidential support, by the Gramm-Leach-Bliley Act in 1999, and administration economic advisors Larry Summers and Robert Rubin (along with Fed chair Alan Greenspan) formed a bi-partisan alliance with congressional Republican deregulators led by Texas Senator Phil Gramm to loosen the last restraints on financial creativity. When those fateful regulatory actions of 1999-2000 and the Bush era's broadbased deregulation program are undone with a new surge of financial regulation this year, we may well see the old financial populism reborn in Congress, with a mostly Democratic coalition (perhaps joined by a few farm region

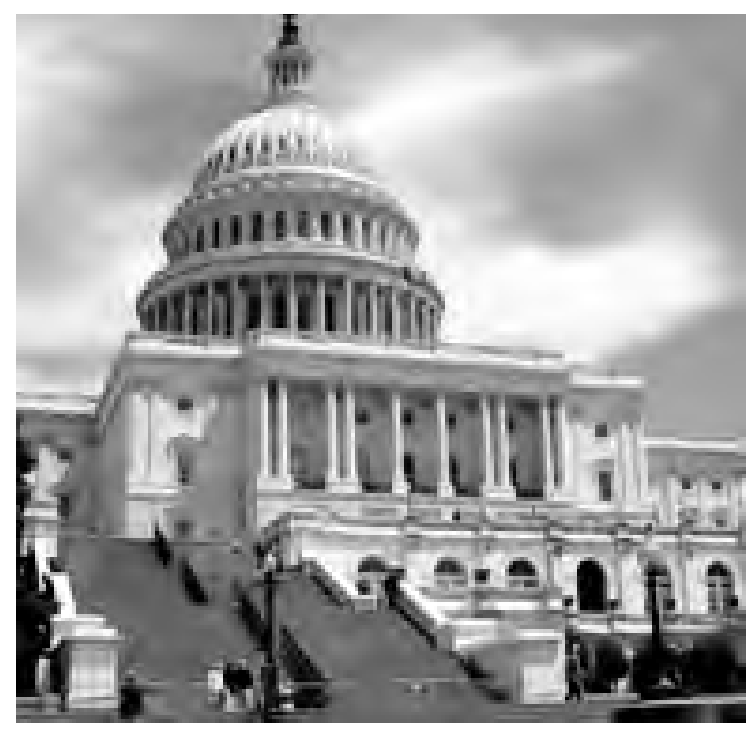

The U.S. Capitol Building, in Washington D.C.

Republicans). It will probably resemble the Democratic-led populist coalitions of the early 1980s and 1990s.

The Republican Party has currently retreated to its southern/plains/mountain bastions (regions that were, in fact, the 1892 populist/Democratic base, but now constitute the electoral map's solid red regions); but red/blue polarization appears more prominently on taxation and budget matters. In this economically remarkable period, the commitment to rebuilding a strong regulatory system may enjoy some bipartisan support. ${ }^{21}$ One of the interesting debates will 
be on whether to make the Federal Reserve Board the national "systemic regulator" with extensive discretion to supervise and intervene in the practices of financial and insurance firms deemed too large to fail. As discussed above, there are deep reservations in both parties about investing the Fed with this unprecedented and highly discretionary regulatory power. This is particularly true in the House, which has less influence over the Fed (given the Senate's sole participation in confirming executive appointments), and which has historically had a very rocky relationship with the central bankers. Agencies of proven competence (and more respect for Congress) like the Federal Deposit Insurance Corporation, and even the Securities Exchange Commission and Commodity Futures Regulatory Commission as they existed before 2000 have historically enjoyed more popularity in the legislature. But regulatory fragmentation is now recognized as a large part of the problem, so those reservations may have to be overcome, with soothing promises from Fed Chair Bernanke.

President Obama probably saw himself, before the summer of 2008 when the financial crash became so visible, as another "triangulating" president in the Clinton mold. He relied on Clinton's Treasury Secretary Robert Rubin, and his Economic Council chair, Larry Summers, for advice, though their "insider" status and Rubin's role in the deregulation juggernaut and the downfall of Citicorp were evident. He even brought into his advisory circle Paul Volcker, Jimmy Carter's Fed nemesis, despised by congressional populists in the early 1980s. Since taking office, he has continued the Bush administration's bailout policies, with few restrictions on the rescued firms. Like all presidents, he endorses new regulation only if it leaves considerable discretion to his conservative economic policy appointees. He has even used a version of Clinton's "good cop, bad cop" game in trying to convince financial elites to support a modicum of regulation. As he told a recent gathering of major bankers,
"My administration is the only thing between you and the pitchforks."22

What sort of new regulatory system emerges from this president-Congress-Wall Street tug of war will depend on how much societal pressure is felt by members of Congress to punish the capitalists who brought down the world economy, and keep them from doing it again. In severe crises, as Frances Fox Piven and Richard Cloward have argued, economic elites are discredited and an opening to the left appears, which, in combination with social unrest and mobilization of the havenots, can produce rare episodes of reform. ${ }^{23}$ But as IMF economist Simon Johnson argues, the elite American financiers who caused the crisis, with their "ever larger gambles with the implicit backing of the government, until the inevitable collapse,... are now using their influence to prevent precisely the sorts of reforms that are needed, and fast, to pull the economy out of a nosedive."24

The New Deal did dethrone some of the era's financial oligarchs, but Johnson is pessimistic that today's financial elite, more powerful than ever, can be persuaded, or threatened, to allow re-regulation. What is really needed, he argues, is to break up the elephantine structure of economic and political power that is today's financial sector. ${ }^{25}$

The New Deal was able to do this to the worst surviving offenders-the public utility behemoths that had defrauded so many investors. The 1935 Public Utility Holding Company Act that broke them up into less powerful pieces was a populist triumph that seems impossible today. Indeed, the Obama administration (like its predecessor) is going the other way. It is encouraging banks and investment firms to merge, and helping the giants to stay afloat with public subsidies. The administration is even working to help the large bailed-out firms escape congressionally-mandated restrictions, with Treasury-discovered loopholes and Enronstyle special entities. ${ }^{26}$ Given the huge sums candidates in the U.S. electoral system have 
to raise, and the increasingly "plebiscitary"27 nature of presidents who are self-recruited and self-financed (rather than chosen and supported by their party activists and officials, or public funding), the power of those with large reserves of cash for electoral campaigns may have passed a tipping point that leaves regulatory populism impotent.
It is, however, too early to rule out that the politically-astute president will join the gang with the pitchforks. Certainly, the fact that the ranks of the pitchfork wielders have now swelled to include French and German leaders will increase the pressure on Obama to raise a trident of his own.

\section{Endnotes}

1 "Will There Be Blood?" an alarmed Economist asked on March 26, incongruously placing that headline above a photo of a well-dressed mature woman carrying a "No More Greed" sign in front of the National Bank of New Hampshire. More evidence of this ominous "spasm of fury" could be found, in the journal's view, in "a recent Harris poll show[ing] that $85 \%$ of Americans believe that big companies have too much influence on politicians and policymakers." Surveys also revealed that "The proportion of people expressing "a great deal of confidence" fell from $30 \%$ in 2000 to $16 \%$ in 2008 for big business, from $30 \%$ to $19 \%$ for banks, from $29 \%$ to $20 \%$ for organised religion." Quelle surprise. http://www. economist.com/world/unitedstates/PrinterFriendly.cfm?story id=13375986\&CFID=48720765\&CFTOKEN=83861639. Typically, though, "populist outrage" is evidenced by quotations from Republican congressmen and conservative radio commentators like Rush Limbaugh-representatives whose legitimacy as spokesmen for "Populists" would no doubt be questioned by the original agrarian and labor populists. One historically accurate commentary was the contribution by historian Michael Kazin, author of a much-praised biography of William Jennings Bryan, in Newsweek's cover story on "Populist Rage," March 30, 2009, 23-24. As Kazin summarizes, "At its core, populism in the United States remains what it has always been: a protest by ordinary people who want the system to live up to its stated ideals-fair and honest treatment in the marketplace and a government tilted in favor of the unwealthy masses. The best way for big men, and big women, to respond to such protests is to try to do what is moral, as well as popular-and treat Americans as partners in the grand enterprise of governance."

2 In the fall of 2000 a lame-duck session of Congress passed a little-noticed piece of legislation called the "Commodity Futures Modernization Act." The bill kept the market for derivatives, credit default swaps and other exotic instruments off-limits to agencies that regulate more conventional assets like stocks, bonds and futures contracts. It was sponsored by Republican Senator Phil Gramm, and strongly supported by Pres. Clinton (whose appointees on the Commodity Futures Trading Corporation worked with Gramm to draft it), Alan Greenspan and Treasury Secretary Robert Rubin. The CFTC described it as a measure that would "provide U.S. financial markets the flexibility needed to maintain a leadership role in the global market arena." http://www.cftc.gov/opa/press00/opa4479-00.htm

3 Geithner outlined four broad goals for a new regulatory system in his late March testimony before the House Financial Services Committee: 1. To give a single government regulatory body [most likely the Federal Reserve Board] broad powers to oversee large "systemically important" companies; (2) To provide stronger safeguards for consumers and investors; (3) To close gaps in the regulatory process (increasing hedge fund supervision, regulating the more exotic derivatives like credit default swaps, etc.); and (4) To improve international coordination of financial regulation. The Treasury Secretary and Federal Reserve Chairman have also requested immediate action on a proposal permitting federal regulators to take over and reorganize failed financial institutions not classified as banks (and hence not currently subject to the bank regulatory agencies). Representative Frank, chair of the House committee, has promised action on regulatory overhaul in May, though the administration will press for earlier action on a "systemic risk regulator" for "too large to fail" institutions. However, as Majority Leader Steny Hoyer told CQ, Congress members have become "increasingly wary of executive branch officials asking for broad new powers." Alabama Senator Richard C. Shelby, the ranking Republican on the Senate Banking Committee, also casts a jaded eye on the Fed as systemic risk regulator. "I see the Fed, as a bank regulator, big-time failing the American people," said Shelby. Senate Banking Committee Chairman Chris Dodd is also cautious about vesting so much power in the Federal Reserve Board, so the skepticism approaches a bipartisan consensus. At any rate, large and ambiguous grants of power in the style of the Paulson 2008 bailout bill are unlikely. Congressional Quarterly Weekly Report, March 30, $2009,728$.

http://library.cqpress.com.proxy.library.cornell.edu/cqweekly/document.php?id=weeklyreport111-000003087459\& Accessed March 30, 2009; Edmund L. Andrews and Louise Story, “U.S. to detail Plan to Reign In Finance World," New York Times March $26,2009$.

4 Michael D. Shear and Anthony Faiola, "Nations Craft Hard-Fought Pledge To Repair World Financial System: Plan Aims to Tighten Regulation, Increase Lending, Aid Poor Nations," Washington Post, Friday, April 3, $2009 ;$ A01

5 Kenneth S. Davis, FDR: The New Deal Years 1933-1937 (New York: Random House, 1979), 106-7, $153-55$ and chapter 5, "The Wrecking of the London Conference," 183-93; Elliot Rosen, Roosevelt, the Great Depression, and the Economics of Recovery (Charlottesville: University of Virginia Press, 2005), 28-37.

6 Davis, FDR, 107

7 Ibid, 156.

8 "International policy is, for all the friendship and commonality, always also about representing the interests of one's own country," the German Chancellor recently observed. Nicholas Kulish and Judy Dempsey, "Merkel is Ready to Greet and then Resist Obama," New York Times Global edition, March 30, 2009. Accessed March 30. http:// www.nytimes.com/2009/03/30/world/europe/30merkel.html?ref=global-home\&pagewanted=print

9 A United Nations monetary and financial commission headed by Joseph Stiglitz issued its preliminary recommendations on March 19. They include the establishment of a Global Economic Council to co-ordinate economic policy, a Global Financial Regulatory Authority to undertake "deep and pervasive reforms in international financial transactions," and a Financial Products Safety Commission. International bodies would establish some degree of supervision over derivatives and credit rating agencies, as well as other processes. See United Nations,

"Recommendations by the Commission of Experts of the President of the General Assembly on reforms of the international monetary and financial system," March 19, 2009.

http://www.un.org/ga/president/63/commission/financial commission.shtml

Accessed March 30, 2009.

10 On regulatory state expansion in the Populist and progressive eras, see Arthur S. Link, Wilson, a biography in five volumes (Princeton, N.J.: Princeton University Press, 1947-1965); and Elizabeth Sanders, Roots of Reform (Chicago: University of Chicago Press, 1999); on New Deal regulatory politics, see Davis, FDR: The New Deal Years.

11 Davis, ibid, 48. In 2009, as squads of expert accountants from the FDIC daily move into failing banks to reorganize them and protect the savings of depositors (much as agents from the regional Federal Reserve Banks did during the "Bank Holiday" of 1933), millions of Americans may count among their blessings that the impressively well-functioning FDIC was never dismantled, despite the 
continual protests of neoliberals that the system protected the weak against the salubrious Darwinian forces of the market.

12 Sanders, Roots of Reform, 479 n. 56.

13 See the list of hearings at the web site of the House of Representatives Committee on Financial Services, http://financialservices.house.gov/hearings_all.shtml

14 In the early 1980 s, the House banking committee was at the center of a fierce congressional campaign to take control of monetary policy away from the Federal Reserve Board, which, under Paul Volcker, was actively pursuing a deflationary policy unprecedented since 1932, with the consequence of high unemployment and business failures. Again in the early 1990s, the committee was in revolt against Fed deflationary policies that had had led to recession. See, on these interesting "populist" battles, Donald F. Kettl, Leadership at the Fed (New Haven: Yale University Press, 1986); William Greider, Secrets of the Temple,(New York: Simon and Schuster, 1987); and Steven K. Beckner, Back from the Brink (New York, John Wiley, 1996).

15 In the 2008 electoral cycle, the leading campaign donation sector was finance, insurance, and real estate, which gave over $\$ 463$ million in all federal races, a slim majority to Democrats. Barack Obama received over $\$ 38$ million from the sector, leading John McCain by $\$ 10$ million. Chris Dodd's presidential campaign received \$5.6 million. In the House, the average Democratic and Republican candidates who received contributions from this sector (and most did) got about $\$ 200$ thousand. Rep. Rahm Emmanuel, now Obama's Chief of Staff, was the fifth highest recipient, with about $\$ 1.1$ million. For the Securities and Investment industry component of this sector, the average House recipient got about $\$ 44$ thousand; the average Senate recipient, about $\$ 480$ thousand. Rahm Emmanuel topped that list in the House, with $\$ 660$ thousand; Barney Frank got $\$ 236$ thousand. Senators and presidential candidates Obama, McCain, and Clinton topped the Senate list of Securities and Investment industry donations. Chris Dodd was fourth, with $\$ 2.9$ million. (Figures taken from

http://www.opensecrets.org, accessed March 30, 2009). Dodd's closeness to, and previous services provided to and from large financial firms, have brought him such bad publicity that he may have a Democratic opponent in the primary, as well as strong Republican opposition for his 2010 reelection bid. That could encourage a new regulatory toughness on the Senate Banking Chair's part. See CNN Political Ticker, March 31, 2009. http://politicalticker.blogs.cnn.com/category/christopher-dodd/. Accessed April 4.

16 Cyrus Sanati, “From Rep. Frank, a To-Do List for Changing Wall Street," New York Times, March 25, 2009. The House on April 1 passed, by 247-171, the Grayson-Himes "Pay for Performance" bill to tie executive compensation at firms receiving federal bailout funds to actual performance. http:// www.nytimes.com/2009/03/26/business/26frank.html?scp=3\&sq=Barney\%20Frank\&st=cse Accessed March 30, 2009. $\otimes$ This bill was passed for the sake of our financial survival, $\bigotimes$ Rep Grayson (D FL) reported. $\bigotimes$ Taxpayers should not bankroll executives whose ridiculous gambles brought America冈s financial system to the brink of collapse. The power the bill grants is pretty standard. The taxpayers now have an ownership stake in these companies. And owners of companies set salaries for their employees. Any company bent on paying its employees unreasonable and excessive compensation can do so after the American taxpayers get their money back. $\nabla$ House Committee on Financial Services, April 1, 2010. http://financialservices.house.gov/ExecutiveCompensation.html. A stronger bill sponsored by Democratic Representative John Conyers had received a much closer House vote of 223-196, reflecting the discomfort of Republicans and 31 more conservative Democrats with the concept of government regulation of executive pay. The president also opposed the stronger bill. The alternative Grayson-Hines bill leaves much to Treasury discretion in setting standards for executive pay in the companies bailed out under the Troubled Asset Relief Program's $\$ 700$ billion dollars. Like a March bill denying bonuses to executives of AIG (which passed the House 328-93), the Conyers bill would not likely have passed the Senate. Anne Flaherty, "House Passes New, weaker Bill in AIG Bonus Flap," Associated Press, April 1, 2009.

17 Tony Czuczha and Mark Deen, "Merkel, Sarkozy Step Up Calls for Tighter Market Regulation," Bloomberg.com, April 1. http://www.bloomberg.com/apps/news?pid=20601087\&sid=auX5y02WWbml\&refer=home

18 Legislative specificity is the way Congress maintains control of the implementation of policy. The executive branch, on the other hand, prefers wide discretion. The difference in preference is especially marked when there is divided party government. A good example is the three-page bank bailout bill submitted by Treasury Secretary Henry Paulson in September, 2008. The bill ultimately passed by Congress had grown to 104 pages, with significantly reduced (although still large) executive discretion.

19 I have analyzed the history of financial populism in an unpublished paper

entitled, "Congress and the Politics of Monetary Policy," presented at the annual meetings of the

American Political Science Association, September 3, 2000.

20 Steven K. Beckner, Back from the Brink. Sanders, "Congress and the Politics of Monetary Policy." The prime mover in the House, after the retirement of old school Texas populist Wright Patman, was Henry B. Gonzales of San Antonio Texas, a latter-day southern urban populist whose district had high unemployment, a very low median income, and half the mean percentage of households with interest income. In the Senate, eight Democrats and eight Republicans opposed Paul Volcker's reappointment as Chair of the FRB in 1983: Democrats Heflin (AL), DeConcini (AZ), Cranston (CA), Kennedy (MA), Meltzer (MT), Metzenbaum (OH), Boren (OK), and Sasser (TN). The Republicans who joined the anti-Volcker coalition were Hawkins (FL), Sims and McClure (ID), Humphrey (NH), Helms (NC), Nickles (OK), Hatch (UT), and Wallop (WY).

21 See note 16. There is, however, growing Republican uneasiness with limits on executive pay, for fear that even pay caps or bonus criteria restricted to bailed-out firms could set a dangerous precedent. See the conflict occasioned by the House Finance Committee's earlier (2007) bill to have shareholder votes on executive compensation. http://www.house.gov/apps/list/speech/financialsvcs_dem/mu032107.shtml.

22 Eamon Javers, "Inside Obama's Bank CEO Meeting,"Politico.com, April 2, 2009. http://dyn.politico. com/printstory.cfm?uuid=6CD55D64-18FE-70B2-A89B1EF075F993F4

23 Poor People's Movements (New York: Random House, Vintage Books, 1977), 28-32, 113-33, $172-75$

24 Simon Johnson, "The Quiet Coup," Atlantic May 2009. Online at

http://www.theatlantic.com/doc/200905/imf-advice

25 lbid.

26 So charge Amit R. Paley and David Cho in "Officials Aim to Help firms Avoid Bailout Restrictions," Washington Post, April 4, 2009, A01.

27 The term was popularized and anchored by Theodore J. Lowi, The Personal President (Ithaca:

Cornell University Press, 1984).

Photo's Courtesy of:

"FDR's Cabinet." University of San Diego. 4 April 2009. < http://history.sandiego.edu/GEN/WW2tIMELINE/fdr-images.html>

"U.S. Capitol Building."Wikipedia. 4 April 2009. < http://en.wikipedia.org/wiki/File:Uscapitolindaylight.jpg> 


\section{The Case for America's Continued Superpower Status}

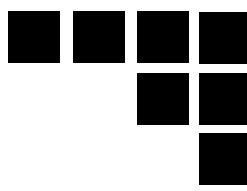

\section{Dennis Shiraev, Cornell 2012 \\ Arts and Sciences: Economics and Mathematics Majors \\ Grant Gibson, Georgetown 2012 \\ School of Foreign Service: International Relations Major}

Is America really in decline as a global superpower? We examine current arguments for America's economic decline and argue that a purely economic analysis is insufficient for evaluating a country's status as a global superpower. Our comprehensive definition of superpower incorporates military strength, internal stability, and the global attractiveness of a state's culture and ideology that it presents to the rest of the world. America is the only state fitting of this comprehensive definition of a superpower in the 21st century, while all other states frequently cited as emerging global powers fail to meet the criteria we lay out in this paper.

The Rationale Behind American Decline

Obama's presidency comes against a growing consensus that America is in the beginning phases of decline as the definitive global superpower. In 2009, GDP estimates and growth figures point to an increasingly diminished role of the United States in the global economy. ${ }^{1}$ As America faces what many consider to be the worst economic crisis since the Great Depression, many have also begun to question the credibility of the United States as the financial center of the modern world. Is there a case to be made for America's economic decline, and will America's reduced economic status in the $21 \mathrm{st}$ century compromise its role as the world's sole superpower?

To be sure, theories about the decline of America's power are as old as American power itself. During the 1960's, the Soviet Union's charge into space, economic growth, nuclear strengthening, and the increasing spread of communism around the world served as the bases for many theories on America's demise from security and economic perspectives. In light of American failures in Vietnam and the continued U.S.-Soviet arms race, the next decade saw more predictions of decline centered around national security. In the 1980's the focus shifted to economics as the world witnessed Japan's rapid economic development and the U.S. began showing signs of over-stretching. With the end of the
Cold War, there was talk of America's moral demise in a post bi-polar world that no longer had single superpower domination. ${ }^{2}$ None of these theories came to fruition, but that is no reason to dismiss more recent concerns without thorough examination.

The economic decline of the United States has been articulated in many arguments, the most prominent of which is that the United States has become a debtor nation, borrowing large sums of money from China as credit for continued economic and budgetary expansion. Chinese possession of large numbers of American T-bills has been cited as a major threat to economic security. Another oft-cited sign of decline has been America's industrial decline, as other nations begin to supplant America's productive role in the world industrial market. Needless to say, the economic concerns confronting the United States are considerable. ${ }^{3}$

There are also more normative arguments. In his Foreign Affairs article, even though he makes clear that the United States is not suffering from internal economic deterioration and will probably maintain its dominant share of the global economic pie, Fareed Zakaria makes the case that the United States will have to eventually accept a diminished global role as a result of the economic rise of the rest. "The rest that are rising are embracing markets, democratic 
government (of some form or another) and greater openness and transparency. It might be a world in which the United States takes up less space, but it is one in which American ideas and ideals are overwhelmingly dominant." Zakaria also points out that the United States' role in global finance is shrinking, with the rising states of Asia and even the established states of the Eurozone playing increasingly important roles in global finance and witnessing a faster overall growth of financial stock.

The recent financial crisis has only strengthened arguments about America's financial decline, adding the questionable future of free-market capitalism into the mix. Resulting from tangible financial losses as well as the loss of financial credibility and confidence, some believe that the global roles of the United States and the European states will shrink in tandem with those countries' economies and financial sectors. ${ }^{5}$

\section{The 21 st Century is Different}

We do not wish to, by any means, dismiss the importance of economics in international relations or global politics, but rather to reconsider the significance of economics as a measuring stick for how we conceive superpowers. As the world progresses into the 21 st century, a purely onedimensional economic evaluation of a state's superpower status has become increasingly insufficient.

One can easily see that, on the most basic level, that a country's economic size and importance as a center of global finance does not necessarily correlate with its importance in international affairs. Economic size is usually measured in GDP, or Gross Domestic Product, which is equal to the total value of domestic consumption, investment, government expenditure, and net exports. Japan, which ranks second in total nominal GDP, holds very little sway in international politics, while countries with increasing regional influence like Iran and Venezuela have economies more than ten times smaller than Japan, by most estimates. $^{6}$

Recent surveys of the world's top financial centers also blur the connection between the importance of a state's financial sector and its influence in global affairs. In a 2008 survey of the world's top financial centers, one will find the Swiss cities of Geneva and Zurich ranked seventh and fifth, respectively. ${ }^{7}$ Two things appear clear: having top financial centers within a state's borders does not qualify it as a superpower (Switzerland), nor does the absence of a top financial center disqualify a country from having prominence as a regional or global power (ex. Russia, India, Venezuela, Brazil, France, Saudi Arabia, Iran).

The increasing pace of globalization has also complicated the importance of a country's GDP figures as a determinant of its influence in international affairs. The rise of the United States as a global superpower came about mainly as a result of the long standing American traditions of openness and innovation. The United States owes much of its historical ascent to its ability to attract the ingenuity of vastly diversegroups of peopleand to channel that human capital into industrial innovation and economic dynamism. ${ }^{8}$ World War One gave America an opportunity to showcase its might as a regional power, and after the Second World War left most of Europe in complete ruin, the balance of power shifted westward and America established itself as a premiere global superpower. But, historical circumstance aside, what made America into the economic giant that it is today? We maintain that it was a distinctly American commitment to innovation, industrialization, open trade and liberalized economics that shot America onto the global scene and kept it there for the remainder of the 20th century. This is where America derived much of its original advantage over other countries, but as more and more countries embrace democratic governments, open trade policies and market-oriented economies, it is no wonder that America's share of the global 
GDP pie will diminish to some extent. Zakaria provides an elaboration of this concept: "Over the last 20 years, globalization has been gaining breadth and depth. More countries are making goods, communications technology has been leveling the playing field, capital has been free to move across the world-and the United States has benefited massively from these trends." In many respects, the world has become more of a leveled playing field where economic imbalances are likely to have less pronouncement. Pure GDP comparisons are no longer sufficient.

\section{Towards a More Comprehensive Definition}

A more comprehensive definition of superpower is needed for the increasingly globalized world of the 21st century. We stress at least three factors: the importance of military capabilities (along with the concomitant influences of these capabilities), internal stability, and the global attractiveness of a state's culture and ideology. The intention here is not to overlook economics-we have already shown why a purely economic evaluation is insufficient, and all of these three criteria are dependent on the existence of a functional economy. Of all of today's powers, the United States is the only one that possesses significant strength in all three categories.

In the 21st century, a state's military strength will remain relevant for its sway in international affairs. But many would argue

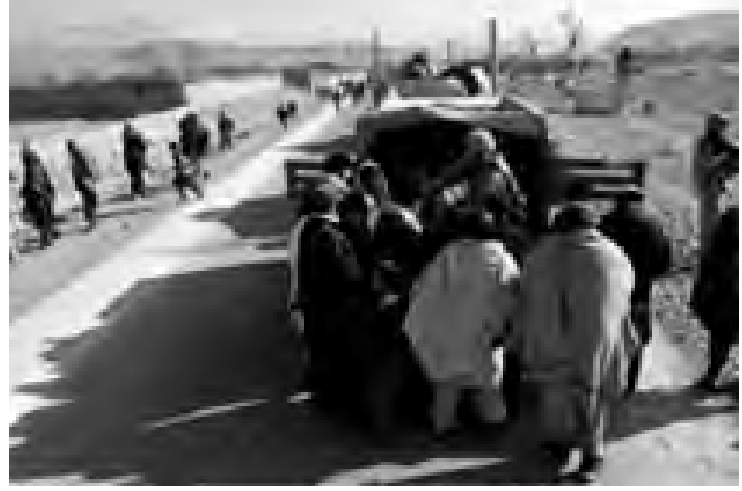

Local villagers in Afganistan receive aid from US military forces that, because of the decreasing fear of direct attack between established nation states, military force is no longer as relevant in the 21 st century. Moreover, many economic and ecological goals of growing importance are not achievable through military means. ${ }^{9}$ To a certain extent, we agree that pure military force and second-strike capabilities are perhaps less important than they were before, but the military aspect of state's superpower status cannot be overlooked. The ability to project power around the world is of paramount importance to any superpower, and, as recent operationsin Panama,Haiti,Somalia, thePersian Gulf, and Afghanistan show, coercion remains a strong force in international diplomacy. The first element of military strength is a simple relative advantage over other states. The ability to easily deter and defeat potential threats and enemies will always be a top military objective for any superpower. Additionally, defense and security obligations are a way for a potential superpower to expand its power. By guaranteeing the security of other states, the superpower forces protected countries to buy into the international system that serves the best interest of their protector. Training missions are another way of extending geopolitical power through military means. Military training enhances the military capabilities of allies while building important cross-military ties that serve to strengthen future relations. Finally, military arms sales are invaluable for international influence. Besides strengthening the diplomatic relationship between a superpower and an ally or potential ally, arms sales symbolize a commitment and high level of trust between the buyer and the seller. Buyer states trust that these weapons will not be used against its interests while the seller state trusts the buyer to both help supply the spare parts and the training for the weapons.

The U.S. is the global military leader on both of these fronts. The size of the United States' economy also allows it to outspend the rest of the world in military expenditures while 
utilizing less than $5 \%$ of its GDP on military spending. ${ }^{10}$ The United States has utilized these expenditures to create a force at least twenty years ahead of its closest competitors. The money invested in the late eighties and early nineties gave birth to a generation of military hardware that has yet to be matched by any country. The American ability to project power is also unrivaled. During the first Persian Gulf War, American generals were frustrated by their inability to build up substantial forces in Kuwait quickly. Since then, the United States has greatly expanded its ability to quickly deploy forces anywhere in the world on short notice. Aircraft carriers, amphibious assault ships, ballistic submarines, and long-range bombers give the United States the unprecedented ability to rapidly project force anywhere in the world. American military power is an especially potent tool because it is one of the most fungible forms of power. Fungibility is the ability of one form of power to influence other realms of influence. ${ }^{11}$ Military power is highly fungible because it influences diplomatic relations and political decisions. American military power not only allows dominance in battle but also holds much influence over other areas of influence.

The second criterion for a superpower, one greatly overlooked by those who argue for the decline of America and the rise of other regional powers, is a state's internal stability. As far as it concerns a superpower's leverage and maneuverability in international relations, internal stability is crucial because a state must beabletomakeforeign policydecisionswithout the looming threat of its citizens revolting against and taking over the government. This is by no means an endorsement of governments not being held accountable to the people who elect them. Quite the opposite: the state must be accountable, but only through welldefined and respected means of electing, changing, and transferring power. Internal stability also concerns societal stability, ethnic harmony, and the absence of destabilizing separatist movements. It is not our intention here to overlook deficiencies and inequalities in American society, but we do argue that American society and the American institution of democracy are and will remain stable. We need not look further than the last fifteen years of American history to see just how stable our institutions really are. In this period, Americans witnessed presidential impeachment hearings, an historic 2000 election that challenged the very roots of our legal processes, a domestic terrorist attack that cost the lives of more than 2,000 citizens, and two foreign wars. And yet, the fabric of American society held together, and the system continued to work. The election of Barack Obama as the forty forth President of the United States is just another indication of the societal progress that America has made and will continue to make in the future.

Although our first two superpower criteria are more fitting of a realist perspective, we cannot avoid taking a neoliberal perspective in advocating the importance of a state's culture and ideology that it presents to the rest of the world. Joseph Nye's concept of soft power comes into play here. A nation, by pure virtue of its identity, can attract nations to its influence and expand its relative power in the world. This identity is composed of a nation's values and culture. A sellable culture and ideology is necessary for a superpower not just for material purposes such as attracting immigrantsbutalsofortheimmaterial objective of creating a positive global perception. If we integrate a constructivist standpoint-which maintains that the structures of international relations among states are determined by shared ideas instead of material forces-into our comprehensive definition of superpower, then the global perception of a superpower's culture and ideology is just as important as the superpower's military might and internal stability. ${ }^{12}$ We cannot speak for the peoples of the world, nor can we make a claim about how citizens of different states perceive the United States. But we believe we can make a case for the culture and ideological image of America that most Americans would like to project to the 
rest of the world: one characterized by limitless individual possibility and a commitment to democracy and capitalism. The New York Yankees, Coca-Cola, and McDonald's arches are perhaps the greatest symbols of the global appeal of American culture and America's superpower status. Critics of this constructivist view would question the value of soft power. As an answer to this, we would point to Nazi Germany as a nation that possessed the more traditional means of power, but didn't have a culture that attracted other nations to its side. Only through force was German hegemony maintained in Central Europe. Had Germany held cultural and ideological sway over its Central European allies, then its allies would not have defected over to the Allied side at the first opportunity. America, on the other hand, has very strong allies because it holds a tremendous amount of cultural influence. This is the mechanism through which an attractive culture and ideology translates into international influence.

\section{The Case Against The Rest}

The United States is not simply fitting of this comprehensive definition of superpower-it is the only state that is and will be fitting of a unipolar superpower status in the foreseeable future. No other state or region of the world is fitting of this denotation.

The Russian Federation has been mentioned by Zakaria as a country on the rise, ascending to its old status as a world leader and power. However, the Russian Federation does not come close to meeting the definition of a superpower that has been set forth in this paper. Militarily, Russia remains a shadow of its former self. Neglect has left large stocks of weapons useless and a counterproductive, nepotistic and cruel culture has emerged within the military community. Additionally, the Russian military never fully designed and produced a set of weaponry comparable in quality to weaponry produced by the U.S in the eighties.

As for internal stability, the Russian
Federation is in a bad situation. The Caucus republics have grown more and more unstable since the fall of the Soviet Union. Only the presence of the military and heavily armed internal security troops maintains order in these regions. Separatist rebels have found common cause with Al-Qaeda and have become part of an international terrorist network with vast resources. These networks have already struck within Russia with great effect. Partly as a consequence of the increasingly authoritarian government-which is moving further and further away from even the most imaginative conceptions of a democratic state-there is little respect for property rights. Organized crime and corruption have corroded the average individual's ability to hold and invest in property. ${ }^{13}$

Russia ultimately lacks something that it possessed with great strength throughout the Cold War: an ideology with universal appeal. Communism was at times very popular in countries crucial to Russian national security interests, but Russian nationalism is no substitute for communism and does not give the Russian Federation the amount of international leverage possessed by the Soviet Union. Russia will only be relegated to the role of a second-rate power for the foreseeable future.

India, with its rapid growth rate and possession of nuclear weapons might also be described as a rising power capable of assuming a certain level of global leadership. In terms of economic growth, which is necessary for bringing millions of Indian citizens out of poverty, India's long term economic expansion will be hampered by several long-term economic maladies. The socialist legacy of a large bureaucracy hurts growth while a lack of infrastructure will severely limit Indian growth until rectified.

Militarily, India will be limited by the need to defend itself from a hostile Pakistan and an increasingly powerful China. These defensive considerations will forever limit India's ability to project military force beyond 


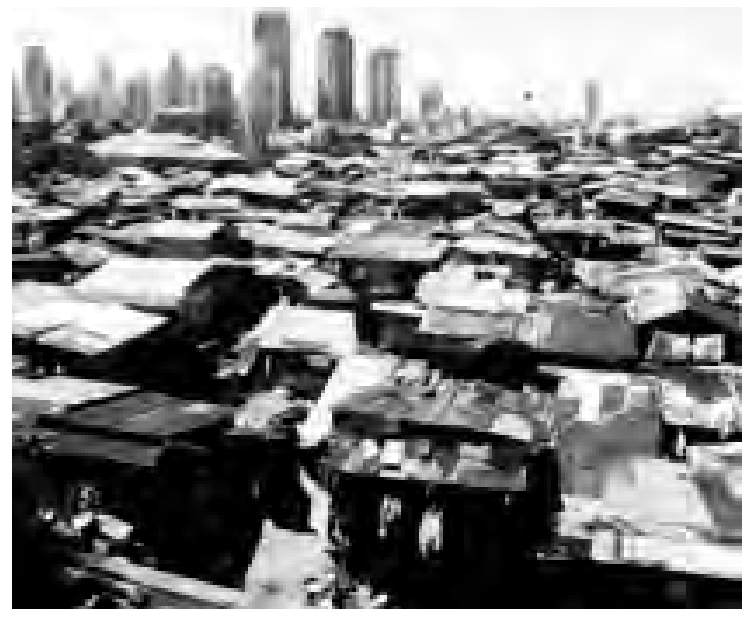

India's sprawling slums are one of the challenges facing India's rise as a superpower

its own borders. Internally, rising Hindu nationalism has added an element of instability to an already volatile domestic scene. Ethnic and religious strife threatens to destabilize regions within India as well as upset the already delicate political balance. If marginalization continues, ethnic and religious minorities may feel compelled to resort to violence to achieve their goals. Finally, although a democracy, India has never really attempted to embrace or export an ideology with broad appeal. The rising Hindu nationalism will only further corrode India's ability to utilize its own soft power. These limitations will undoubtedly hamper India's power for the foreseeable future.

Brazil has in recent years been cited as a power rising in South America that will challenge American hegemony in the Americas. However, Brazil must overcome a myriad of obstacles before it can even begin to be considered a world power, let alone a superpower. Its current growth rate is about five percent but it has yet to develop any solid infrastructure. ${ }^{14}$ Brazil has little ability to project military power beyond its own borders because Brazilian military operations will be confined for the next several decades to South America and to peacekeeping operations. As for internal stability, Brazil is suffering from a crime wave that shows no sign of abetting. Gangs control large swathes of Brasilia and are spreading throughout the country. The drug trade remains rampant, with more groups operating in Brazil's jungle regions, and Brazil's population consuming the second-highest level of cocaine in the Americas. Organized crime and violence associated with the drug trade continues to be a destabilizing threat. As for ideology, Brazil has yet to establish a strong democratic tradition, having only recently emerged from a military dictatorship in 1985. Currently, Brazil is suffering from a great financial crunch that threatens to economically destabilize the country for years to come. Brazil has a long way to go before it can be considered a major power.

The European Union has been described by Mark Leonard as possessing the traits befitting a rising power. Without a doubt, the European Union has a huge share of the world's economic might. However, economic might and influence is the only area in which the EU has substantial clout. Attempts to create a united military command have barely gotten off of the ground, with states reluctant to cede any authority over military affairs. The much-touted rapid reaction force is in actuality only a listing of units that could be made readily available in the event of a crisis. After joining the European Union, Eastern European states were encouraged to actually reduce their military in order to fund services and promote stability. Hardly any Western European countries maintain their defense spending above $2 \%$ of their GDP. ${ }^{15}$ As a result, many European militaries are completely unprepared to mount large independent operations. The European internal political situation is not conducive to quick decision making or even consensus building. This is evidenced by the repeated failure of the passage of the European Constitution. Quick decision making is a luxury not enjoyed by the European Union. The lack of a united national identity makes internal stability a huge problem for the European Union. Risky overseas ventures will never meet the required unanimous consensus required for collective 
action.

It is hard to make a case that the EU has a common culture that is recognizable on the world stage. Additionally, the recent economic crisis has exacerbated tensions within the European Union, with the Eastern European states clamoring for aid that the Western states wish not to give. The frictions exposed by this financial crisis betray the fact that the European Union is incapable of assuming great authority in the international stage. Although the EU may have the potential to act as a world power on the geopolitical stage, it is certainly unable to summon the high threshold of support it needs to do so. It is also worth noting that the EU and the U.S have many goals and interests in common, which curbs European motivation to participate in politics on a greater level with more responsibilities.

China is the state most cited as the rising superpower on the international stage. Its double digit growth rate has impressed many economic analysts while diplomatic success has convinced the world of Chinese foreignpolicy prowess. However, China possesses several glaring weaknesses overlooked in most analyses. First and foremost, the Chinese economy has yet to fully tap into its potentially lucrative but unevenly developed domestic market. Additionally, there are a myriad of state run enterprises that were never privatized, reducing the long-term efficiency of the economy. A weak banking system leaves little protection in times of economic peril. Economic success has also led to the rise of a middle class. This class has unique economic and political needs such as social mobility and certain levels of individual freedom. We can only speculate, but the Chinese government may face problems when giving into the demands of this growing class.

The Chinese have yet to develop a military force capable of projecting overwhelming force on a regional basis. Granted, construction has begun on their new navy, but it will be many years before they even begin to develop a blue-water capacity. ${ }^{16}$
While in possession of some high-quality equipment in certain units, the majority of the People's Liberation Army is still equipped with weapons of inferior quality.

Throughout recent history China has only intervened in its immediate region, casting doubt as to whether or not China would even desire to shoulder the responsibilities of a great power. More importantly, the area where the China's power suffers the most is internal instability. The abandonment of pure, messianic Communism thirty years ago has forced the Chinese to sell a new ideology to their people. This ideology is essentially Han Chinese nationalism with the promise of rapid economic growth. This strategy has so far proven useful, but may prove to be detrimental to long-term security. Han nationalism is a potential powder keg. Failure to meet the expectations of an increasingly nationalistic population could lead to internal destabilization and riots. The uneven distribution of wealth has already led to simmering riots in the country's interior. Further harming stability is the fact that minority populations within China have also become increasingly marginalized, leading some of them to turn to violent resistance against the government. Finally, the promise of economic growth makes support for the government contingent on economic success. This potential for internal instability prevents the Chinese government from taking substantial foreign policy risks. If the Chinese government experienced a major foreign policy failure, it might see a devastating backlash of public opinion. In terms of having an exportable ideology, the abandonment of communism has also left nationalistic China ideologically weakened, limiting its soft influence outside of its own borders.

\section{Conclusion}

For the time being the world will remain unipolar with the United States as the sole global superpower, but will it always remain so? It is highly unlikely that the United States' 
military superiority or internal stability will diminish in the foreseeable future, but the global perception of the United States is much more subject to change. If the United States is to remain the sole global superpower, it must continue to reify the cultural and political principles that made it a global superpower. It must, in a sense, continue to be perceived as the global standard of progress and opportunity, as well as might and influence. The election of Barack Obama, the first African-American president, is a step in the right direction. But the way in which the United States reacts to the financial crisis may be the most important test for Americans. We believe that America must take leadership in leading the world out of the current financial crisis - the United States must act in such a way to save the free market institutions that have driven so much global growth in the past centuries. If the United States fails to take leadership in the global economic recovery process and responds with increased levels of protectionism, it would harm the global attractiveness of its values and ideology and experience a real contraction of its influence in global politics. If America seizes the opportunity to lead the global economy out of the current crisis, this would be the newest reaffirmation of its status as the sole global superpower.

Acknowledgements: We wish to thank the following professors and students for their valuable contributions and commentary: Peter J. Katzenstein, Ambassador H. Allen Holmes, Eric B. Shiraev, Jake Bean, Chris Eng, Michael Jameson, Heide Celeghin, and Ryan Woo.

\section{Endnotes:}

1 "China may overtake US by 2025, but Vietnam may be fastest growing of emerging economies." PriceWaterHouseCoopers. 4 March 2008. http:// www.pwc.com/extweb/ncpressrelease.nsf/docid/B99EDBB955503B33852573FE005678F5

2 Shiraev, Eric, and Vlad Zubok. International Relations in an Uncertain World. New York: McGraw Hill, forthcoming 2009.

3 Ferguson, Niall. The Ascent of Money: A Financial History of the World. The Penguin Press, New York, 2008.

Zakaria, Fareed. "The Future of American Power." Foreign Affairs May/June 2008: 18-43.

Altman, Roger C. "The Great Crash, 2008." Foreign Affairs January/February 2009: 2-14.

"CIA World Factbook." 8 January 2009. <https://www.cia.gov/library/publications/the-world-factbook/geos/ja.html>

"The World's Top Financial Centers." Business Week. March 2008. 8 January 2009. <http://www.businessweek.com/globalbiz/content/mar2008/ gb2008035 012894.htm?campaign id=rss topStories>

$8{ }^{7}$ Chua, Amy. Day of Empire. New York: Doubleday, 2007.

9 Keohane, Robert O., and Joseph S. Nye. From Power and Interdependence: World Politics in Transition. Addison-Wesley Educational Publishers, 1989.

10 "CIA World Factbook." 8 January 2009. <https://www.cia.gov/library/publications/the-world-factbook/geos/us.html>

11 Art, Robert J., and Robert Jervis. International Politics: Enduring Concepts and Contemporary Issues. Pearson Education, 2009.

12 Wendt, Alexander. Social Theory of International Politics. Cabridge: Cambridge University Press, 1999.

13 Nye, Joseph. Soft Power: The Means to Success in Modern Politics. New York: Perseus Book Groups, 2004.

14 Greenspan, Alan. The Age of Turbulence: Adventures in a New World. New York: Penguin Group, 2007.

15 "Trends in European Defense Spending, 2001-2006." Center for Strategic and International Studies. April 2008. 8 January 2009 <http://www.Csis. org/media/csis/pubs/080424-chao-europeandefense.pdf>

16 "Warship Modernization." GlobalSecurity.org. 8 January 2009. < http://www.globalsecurity.org/military/world/china/plan-mod.htm>

Staff Sgt. Davis, Tiffani L. "Local villagers recieve humanitarian aid." 14 Jan 2009. US Army. 2 April 2009. <http://www.army.mil/yearinphotos/2008/>

"Rooftops of Indias Slums." Concurring Opinions. 4 April 2009. < www.concurringopinions.com/.../> 


\section{United States Policy and Latin America an Interview with former Secretary General of the Organization of American States}
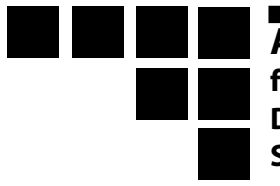

\section{Ambassador Luigi R. Einaudi \\ former Secretary General of the Organization of American States \\ Distinguished Visiting Fellow at the Institute for National \\ Strategic Studies, National Defense University}

Ambassador Einaudi spoke at Cornell at the invitation of the Mario Einaudi Center for International Studies to commemorate the 20th anniversary of the Luigi Einaudi Chair in European and International Studies named after his grand-father. The Board of the Cornell International Affairs Review had the privilege of conducting an interview with him during his visit. The following article, produced here with his permission, is an edited transcript of this interview. The Board of the Cornell International Affairs Review thanks Ambassador Einaudi for his support.

The United States under the new administration has a chance to develop the good foreign policy towards Latin America it needs. But it first needs a good global foreign policy. The United States, after all, has a global reach and global involvements. Latin American countries do too, even if to a lesser extent. I recommend no special policy for Latin America. The United States needs a global policy, before defining regional policies. US global policy has been a failure in the last years. It has not supported international rule of law. It has not fostered cooperation on global issues beyond its immediate interests, and consequently, left itself unable to obtain the spontaneous cooperation of other countries. To have a good overall foreign policy the United States must begin by supporting international law through the existing institutions and body of laws such as the International Criminal Court, law of the sea treaty, active participation in environment and human rights. The unilateral intervention in Iraq, for instance, was chilling for Latin America, given the importance of international law in the region and the complete ill-regard of the United States in by-passing several conditions agreed to in international treaties. The single most important necessity for the United States is to restore a sense of US respect for international law, and accepting existing treaties. The United States needs to put an end to Guantanamo. Rule-based engagement would strengthen the ability of the United States to get support for all its objectives.

\section{What countries matter for United} States foreign policy? They all matter. The problem with the Bush administration is that it did not listen. Other countries felt

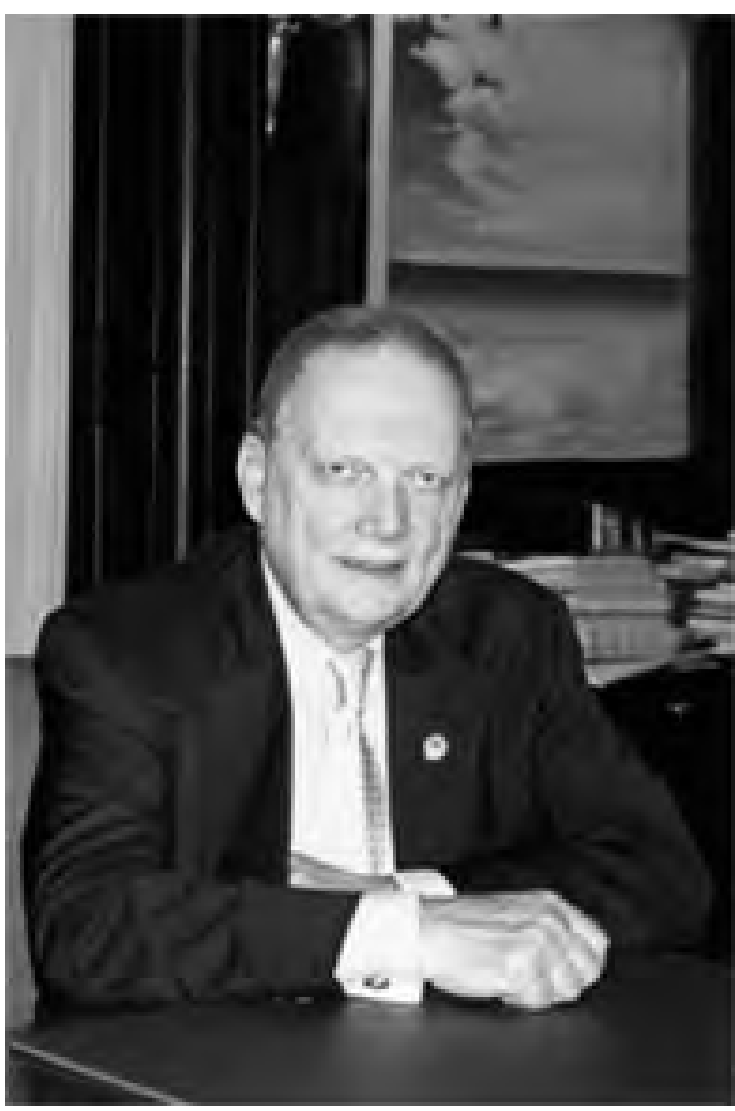

Ambassador Luigi R. Einaudi 
ignored and humiliated. To correct this, the next Administration will need to listen and to strengthen US representation in international organizations. This would increase its ability to participate in international dialogue. The United States needs a diplomatic surge. For that, it needs to improve the training of its people to be involved in foreign affairs. The United States should require its senior foreign service and civil servants to serve in an international organization at some point in their career. In the $21^{\text {st }}$ century, we can't solve problems alone. We need the cooperation of other countries to make our power more effective. The United States needs to learn to cooperate.

All countries are not the same. Some countries punch above their weight. Brazil, Mexico, Canada, have influence because they have good policies as well as size. But smaller countries also need to be paid attention to as well. We have to look at the sub-regional settings.

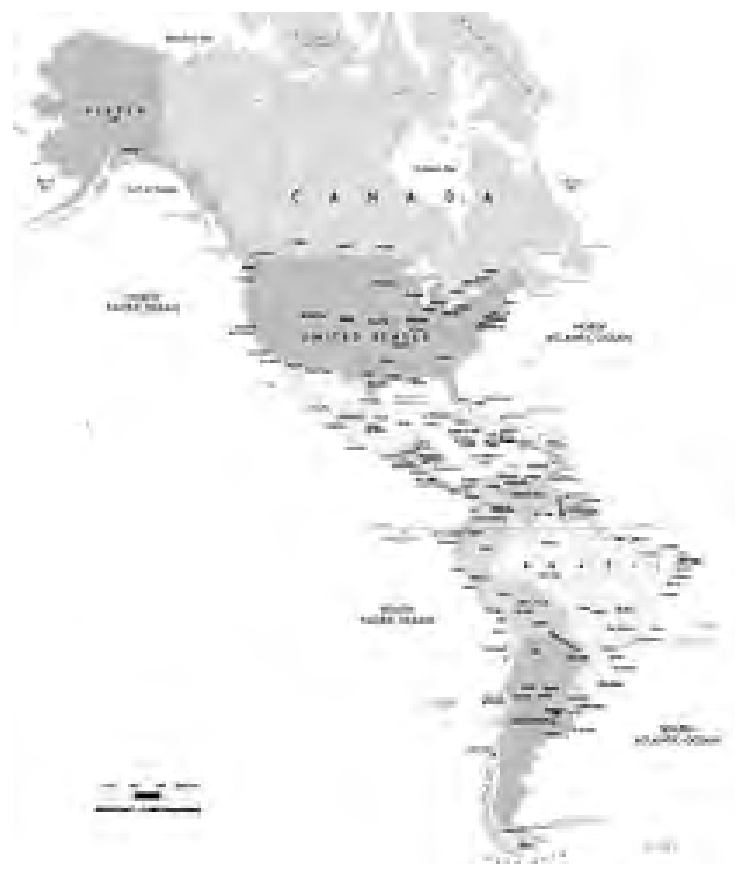

The United States needs a better policy to address trade issues as well. Most Latin Americans believe in free trade, but do not support how it has been approached, because its social and political costs have not been addressed. Even inside the United States, voices have risen against free trade. Free trade has huge impacts everywhere, and it is necessary to do a better job of taking social dislocations into account. The United States also needs to change its approach in sectors where its protectionism has traditionally belied its rhetoric, such as steel and agriculture. Conversely, the flow of small weapons through the United States towards Latin America - particularly Mexico - has been far too free. That is one illegal activity that must be stopped.

Another problem is the migration policy and the deportations that are carried out, sometimes without even informing our neighbors. We have every right to deport aliens who have committed crimes, but when we deport them, we must account for the impact on the receiving country, or we will simply be strengthening international gangs and transnational crime.

A "European Union" of the Americas is out of the question. Cooperation in the Western Hemisphere is defined politically, not economically. In the EU, there is an obligation of richer states toward poorer states. The United States is not prepared to subsidize its neighbors' weaker economies as happens in the European Union. Moreover, from a Latin American perspective, the United States is an unreliable partner and has too much power already. Smaller countries see their sovereignty threatened by the United States. And in fact, the United States is also not interested in sacrificing sovereignty, even to attain common objectives. At this point, it would be important for more Americans to understand that sovereignty can be strengthened through cooperation.

A functioning EU of Latin America without the United States is also unlikely. Most of the region's countries have a greater tradition of uniting against the United States than in cooperating with each other. 
Latin America is not a cooperative region. The tragedy of Venezuela, for example, is petroleum. The revenues have never been properly distributed. Chavez is a product of the people who preceded him. In the mid-1970s Venezuela asserted control over the operations of petroleum companies and created PDVSA. Venezuela has yet to find a working formula. In the words of Mariategui, "the independent history of each of Latin America's countries is an anti-history of each of its neighbors."

The disparity of power between the United States and its neighbors creates many special problems. But if the United States had better relations with other major world countries, it would also improve relations with Latin America. It is a mistake to think that Latin America can be carved out from the world. The times of the Monroe Doctrine are over. For example, relations between Latin America and China are growing, are good for the economy, and therefore in the interest of the United States, as it wants to have stable and prosperous neighbors. Moreover, in today's world, unless these countries can deal with others, they won't be stable. outlook in Latin America, but it does not have a colonialist outlook. An imperial outlook lacks the element of responsibility which comes with colonialism. Latin Americans often think that the United States wants to influence them more than it really does. The American imperial outlook is not regionally defined, but globally defined. US political leaders tend to think that US power is essential to the stability all regions of the world, not just to Latin America. And US businessmen also have a global outlook. When NAFTA was signed, for example, some American business men were not happy, as they saw their interests as global, and thought they might be limited to this hemisphere.

The Organization of American States, OAS is not the Monroe doctrine. The survival of a functioning western hemisphere relationship is of as much interest for Latin America as for the United States. The problem with the OAS is that the United States lacks the interest to work seriously on regional problems such as drugs and the environment that require a multilateral framework to be dealt with successfully. Regionalism can be very helpful but it must be founded on the basis of universal principles, participation and support.

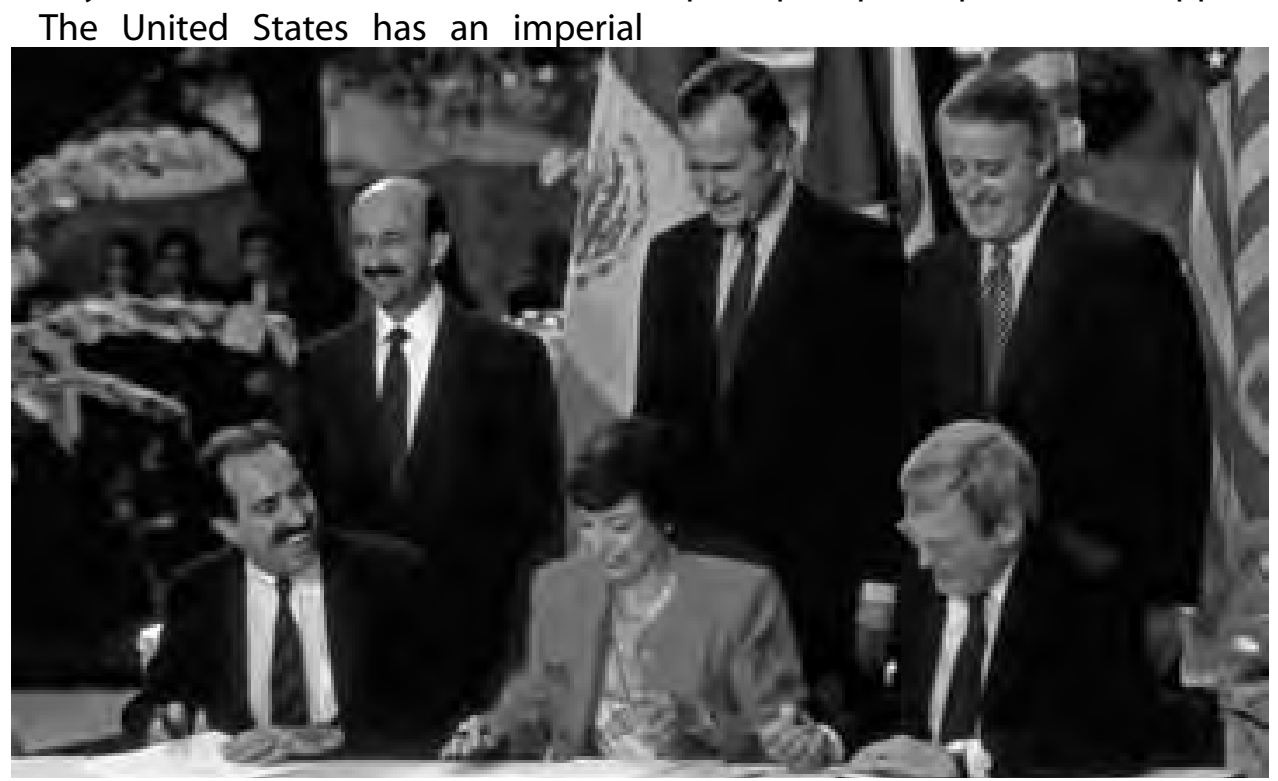

Signing of the NAFTA Treaty, December 17, 1992 by U.S. President Bush, Canadian Prime Minister Mulroney, and Mexican President Salinas.

"Luigi R. Einaudi." GERM. 6 April 2009.< http://www.mondialisations.org/php/public/art.php?id=17500\&lan=EN> 


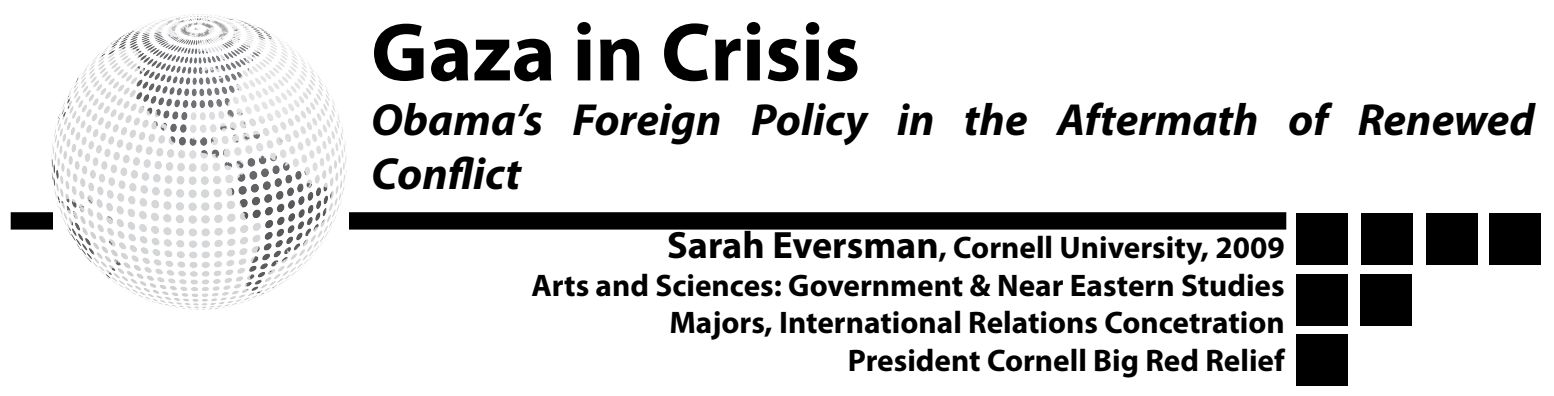

This ongoing dispute clearly concerns the United States, the long-term third party in peace negotiations, and a close ally of Israel. However, now more than ever European and Middle Eastern states are invested in the resolution of this conflict. The stability of Israel and the humanitarian status of the Palestinians depend upon the resolution of this conflict. So, what should President Barack Obama hope to accomplish in the coming months, in light of the overwhelming array of issues already on his agenda? And what should the rest of the world expect from U.S. foreign policy regarding the Israeli-Palestinian conflict under Mr. Obama's administration?

Political maneuvering is already underway and the recent elections in Israel have shifted the power structure of Israeli politics significantly to the right with Benjamin Netanyahu, leader of the right-wing Likud Party, elected as Prime Minister and sworn in at the end of March 2009. Furthermore, Egyptian negotiators are attempting to bridge the deep divide between Fatah and Hamas in order to strengthen the unity of Palestinian politics, but the outcome of this endeavor remains to be seen. As the global economic crisis continues to worsen, the attention of the world shifted from the IsraeliPalestinian conflict to the G-20 Summit and NATO meetings. Therefore, it is the role of world leaders, particularly the United States, to maintain focus on rebuilding Gaza and acting as intermediaries in any Israeli and Palestinian negotiations. Secretary of State Hillary Clinton must ensure the State Department keeps its finger firmly on the pulse of political and social activities in the region in order to prevent renewed fighting.

The United States and Europe should have anticipated more aware of this impending crisis and in the aftermath of the conflict, neither can afford to watch from the sidelines. Dialogue and diplomacy are the way out of this mess, and it is in the interests of both Europe and the U.S. to engage both sides in this dispute if further violence is to be prevented. If Mr. Obama wants to have peace in the Middle East in our time, he will have to persuade all of the actors to sit around a table and to talk about the conflict. The Bush administration's strategy of strengthening Fatah and isolating Hamas has not worked. Secret negotiations are just as ineffectual as the exclusion of certain actors. Only a common platform for dialogue will enable the U.S. and the European Union to fulfill their peacemaking mission.

\section{Timeline of the Crisis}

The Israeli operation began with an intense bombardment of the Gaza Strip targeting Hamas bases, police headquarters and offices, but also more controversially civilian infrastructure including mosques, houses, schools, and medical facilities. Israel claimed many of these buildings were being used by combatants, and as storage spaces for weaponry. Hamas retaliated with attacks on southern Israel, reaching previously untargeted cities such as Beersheba and Ashdod. By the time Israel began its ground invasion into the Gaza Strip on January 3, 2009, 3 Israeli civilians were killed by Palestinian rocket attacks and hundreds of Gazans had been reported killed by Israeli air strikes and rocket fire. These numbers continued to escalate while the humanitarian situation in Gaza rapidly deteriorated.

Many called for an immediate ceasefire and raised valid concerns about the humanitarian repercussions in the Gaza Strip. United Nations Secretary General Ban Ki-Moon 
literally pleaded for an end to the violence saying, "My message is simple, direct and to the point: the fighting must stop. In Gaza, the very foundation of society is being destroyed: people's homes, civic infrastructure, public health facilities and schools." ${ }^{1}$ The United Nations issued Security Council Resolution 1860 that called for "an immediate ceasefire in Gaza leading to a full Israeli withdrawal, unimpeded provision through Gaza of food, fuel and medical treatment, and intensified international arrangements to prevent arms and ammunition smuggling." ${ }^{2}$ All members stressed the importance of an "immediate and durable ceasefire." Unfortunately, the resolution was ineffective, unsuccessful and ignored by Israel and Hamas, who both continued fighting.

As of January 12 the United Nations reported 900 Palestinians killed in the Israeli offensive, and almosthalf of the 3,860 wounded, were women and children. ${ }^{3}$ Furthermore, multiple news sources reported that more than 400,000 Gazans were left without running water and around 4,000 homes had been ruined, leaving tens of thousands of people homeless. ${ }^{4}$ The conflict came to an end on January 18, 2009 after first Israel and then Hamas announced unilateral ceasefires. On January 21 , Israel completed its withdrawal from the Gaza Strip. This was exactly a day after President Obama's inauguration, highlighting the fact that the conflict took place in the remaining days of President George W. Bush's presidency and immediately before President Barack Obama's inauguration. Many analysts surmised that Israel was emboldened in its attack with the knowledge that neither Mr. Bush nor Mr. Obama could legitimately influence the Palestinian or Israeli leadership, with the former a lame duck president and the latter not officially sworn into office.

\section{The Aftermath: Political and Civilian Casualties}

On March 2, 2009 it was reported that international donors pledged $\$ 4.5$ million in

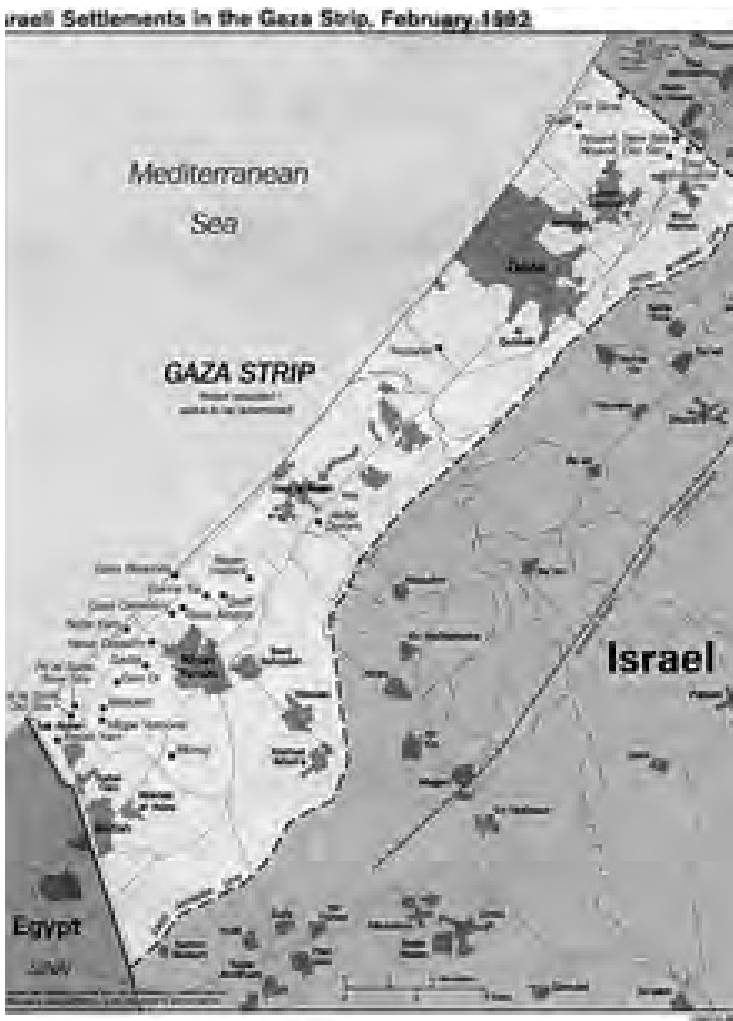

aid for the Palestinians, mainly for rebuilding Gaza after Israel's offensive. ${ }^{5}$ Financial support for Gaza's reconstruction is essential, but rebuilding Gaza is only the first step in the peace process. Improving the political situation will require much more complex and determined diplomatic efforts. If the U.S. had been more aware of the situation on the ground in Israel and Gaza prior to the conflict, it would have been more prepared for the violence to come; it cannot risk being this unprepared yet again. In the build up to the recent crisis both Israel and Hamas violated conditions of the delicate truce agreement. The six-month truce between Hamas and Israel was continually compromised by Israel's blockade on the Gaza Strip and the ongoing barrage of rocket attacks launched into southern Israeli cities by Palestinian militants in the Gaza Strip.

Since Hamas gained power in the Gaza Strip during the summer of 2007, tensions within Palestinian politics have remained high. The intense divide between the two dominant Palestinian political parties, Fatah and Hamas, has further weakened Palestinian unity and the 
ability of Fatah's moderate leader, Mahmoud Abbas, to advocate for Palestinian statehood in any negotiations with Israel and the U.S. On the center-left, Fatah, a faction of the Palestinian Liberation Organization, tentatively maintains its power in the West Bank, although the party is internally divided and tainted by charges of corruption. However, the Islamic paramilitary force of Hamas is unsupported by the U.S. and many European countries that consider the party to be a terrorist organization and an unwilling partner for peace negotiations with Israel.

Yet, the question of Hamas and its status as a terrorist organization are no longer the main focus of the debate. As Richard N. Haass, President of the Council on Foreign Relations wrote in an article in Foreign Affairs, "The way out of this dilemma is to make it clear that Hamas, and not the United States, is responsible for the Gazans' fate. The cease-fire agreement that Egypt negotiated is holding for the moment precisely because the Hamas leadership has effectively policed it, choosing to place the needs of Gazans ahead of Hamas' interest in 'resistance."' ${ }^{\prime \prime}$ The United States should encourage these diplomatic efforts and allow Egypt, Israel, and the Palestinian Authority to address their relationships with Hamas.

The Obama administration must be prepared to put pressure on its ally to prevent

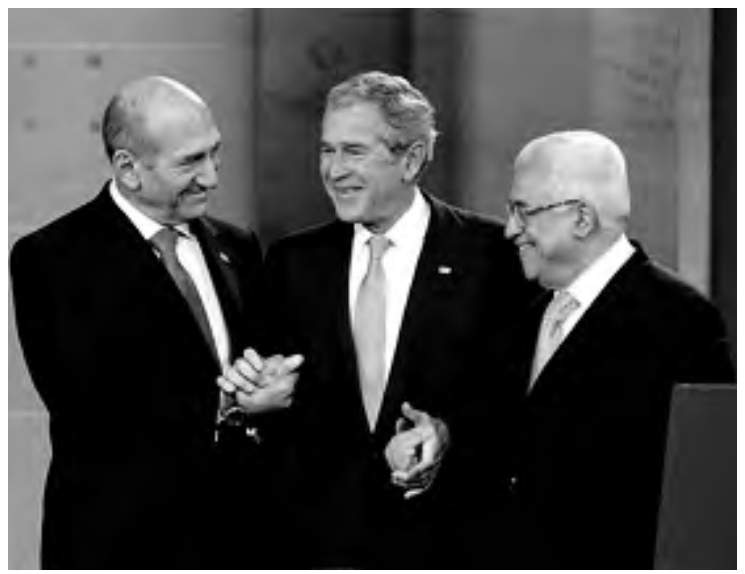

Israeli Prime Minister Ehud Omert, left, President George W. Bush, and Palestinian President Mahmoud Abbas shake hands at the Annapolis Conference, November 2008 further territorial expansion and to moderate its new far-right government; regionally, it must focus on Israel, more than Hamas or Hezbollah. Some promising steps have already been taken by the U.S. to improve Israel's relations with Syria. Mr. Obama's "outstretched" hand has already dispatched two senior officials to Syria for the first time in four years. Improved relations between Syria and Israel are critical because of the power Syria holds over Hamas and Hezbollah. In addition, a renewed strategic relationship could also affect Syria's connections with Iran. As Haass notes, "A U.S.-brokered peace between Israel and Syria would remove Damascus as an enemy and, in the process, likely cause the breakup of the Iranian-Syrian alliance." ${ }^{\prime 7}$

The strategic importance of Iran is critical to the peace process and a reality President Obama clearly acknowledges. He recently attempted to engage the Iranian people via a video message in order to signal a new U.S. approach, albeit coupled with warnings that Tehran's suspected quest for nuclear weapons and support for terrorist groups are unacceptable. Iran is highly important, as former ClA Case Officer and Middle East Specialist Robert Baer explains: "Hezbollah, Hamas, and the Shiite parties in Iraq look to Tehran for financial aid and support. As long as the U.S. does not solve the Israeli-Palestinian conflict Iran's influence will grow." ${ }^{\prime 8}$ Mr. Obama must reengage in the Arab-Israeli peace initiative and strategically engage surrounding states with an integrated approach that considers the regional dynamics. Progress on peacemaking would certainly get Iran's attention and likely cause concern in Tehran that it's bid for regional primacy was failing.

Therefore, while the framework from the Annapolis process remains in place, the Obama administration must resume negotiations and help bridge differences between the players. The inclusion of regional players, particularly Syria, Lebanon, and Jordan, would work to the U.S. advantage, 
in part because these states understand the region much better than does the United States. Furthermore, given how much time the Israelis and the Palestinians have already spent negotiating, U.S.-sponsored solutions should be proposed sooner rather than later. As long as this inaction continues, Iran, Hezbollah, and Hamas continue to benefit from the anger in the Arab street and Muslim world generated from this conflict.

Unfortunately, when it comes to finalstatus negotiations, the Obama administration will have a tough time with this new Israeli government. Some believe that present conditions are not propitious for solving the Palestinian question, and the results of the recent Israeli elections make them even less so. ${ }^{9}$ For example, Avigdor Lieberman, Israel's new foreign minister in Mr. Netanyahu's Likudled government, caused upset and surprise in his first days in office due to a blunt speech in which he declared that Israel was not obligated to continue an American-backed peace effort with the Palestinians, started at a conference in Annapolis, Maryland in late 2007. ${ }^{10}$

In light of this enflamed rhetoric it appears to many that the prospects for peace are fairly bleak. A report published by the Center for Strategic and International Studies this March states that, "This may be the Middle East that Israel and its Arab neighbors have to live with. In fact, there is little hope of a sudden return to a viable peace process.... Israel has to understand that the choice between war and peace will not always be open, and that the Arab peace initiative that is on the table today will not stay on the table."11

If the Obama administration seriously seeks to foster peace it should emphasize the importance of negotiating for a finalstatus agreement. The United States must encourage the Palestinians to crack down on terrorist activities in the territories while concurrently pressing Israel to reengage in the peace process. Before the Gaza conflict both sides took partial steps toward fulfilling their commitments made in the road map for a two- state solution proposed by the Quartet (the European Union, the UN, the United States, and Russia). However, clearly the process is stalled, and because it will take time to come to any final status agreement, the Obama administration should lay the groundwork for deploying international forces and to partner with the Palestinian forces until they can police their own territory. Many analysts, including Martin Indyk, Director of the Saban Center for Middle East Policy at the Brookings Institution, have advocated for the introduction of a peacekeeping force in the region. Indyk argues that, "The key issue is to get a force on the border between Egypt and Gaza that will prevent the smuggling of offensive weapons into Gaza that are then used by Hamas in the future to attack Israeli civilians."

Finally, Mr. Obama should seek the active involvement of Arab states in the peace process. Arab states were ready to commit to the peace process prior to the violence in Gaza. Recently, following in Saudi Arabia's footsteps, the 21 other members of the Arab League offered to sign peace agreements and normalize relations with Israel. Mr. Obama must act upon this moment, and gaining the renewed involvement of the Arab states will be easier if they see that negotiations are progressing and that the reconstruction of Gaza is underway. However, the Arab states need to be more committed to their financial pledges to the Palestinian Authority and to engage more visibly with Israel throughout the process, not just at the end. ${ }^{12}$ Perhaps Mr. Obama's new Middle East Envoy, George Mitchell, can succeed where many others have not. Mr. Obama appointed him to this post after Mitchell played a pivotal role in the Northern Ireland peace process, for which he was awarded the Presidential Medal of Freedom by President Clinton in 1999.

With the Obama administration's renewed emphasis on diplomacy and dialogue it is possible that prospects for peace between Palestinians and Israelis remain. There are many new challenges to confront including 
the hawkish Israeli leadership and the fraught divide between Hamas and Fatah. However, inaction is not an option. By combining new strategies with the Annapolis framework, Mr. Obama could improve Israeli-Syrian relations, engage the Arab states, and indirectly weaken Iran's influence on the region. With an integrated approach Mr. Obama must resume the peace process in the Middle East or be doomed to fail where so many have in the past.

\section{Bibliography}

Cordesman, Anthony. "The Gaza War: A Strategic Analysis." Center for Strategic and International Studies: Washington DC. February 2, 2009.

Gause, Gregory III. "The Return of the Old Middle East: How to Win at Balance-of-Power Politics." March 12, 2009 http://www.

foreignaffairs.com/articles/64844/f-gregory-gause-iii/the-return-of-the-old-middle-east?page=show\#

Haass, Richard and Indyk, Martin. "Beyond Iraq: A New U.S. Strategy for the Middle East." Foreign Affairs. January/February 2009.

Hanelt, Christian-Peter. "After Gaza: A Common Dialogue Platform for the Middle East." Central and Eastern

European Online Library. Spotlight Europe, Issue: 02 / 2009, pgs: 18, www.ceeol.com.

Maqbool, Aleem. "Scale of Gaza Destruction Emerges." January 19, 2009. http://news.bbc.co.uk/1/hi/world/middle_east/7836869.stm

Ravid, Barak and Shamir, Shlomo. "Israel Rejects UN Truce Resolution." Haaretz Correspondents and New

Agencies. January 10, 2009. http://www.haaretz.com/hasen/spages/1054201.html

New Israeli Foreign Minister Dismisses Peace Effort." April 2, 2009.

http://www.nytimes.com/2009/04/02/world/middleeast/02mideast.html? $r=1 \& s c p=2 \&$ sq=lieberman\&st=cse

"Security Council overwhelmingly calls for immediate Gaza ceasefire." UN News Center. January 8, 2009.

http://www.un.org/apps/news/story.asp?NewsID=29495\&Cr=gaza\&Cr1=

"UN chief wants Gaza conflict halt" BBC News Online. January 13, 2009.

http://news.bbc.co.uk/1/hi/world/middle east/7825480.stm

Zakaria, Fareed. CNN GPS. “Crisis in Gaza."Aired January 11, 2009 http://transcripts.cnn.com/TRANSCRIPTS/0901/11/fzgps.01.html

"Billions Pledged to Rebuild Gaza." BBC News Online. March 2, 2009. http://news.bbc.co.uk/1/hi/world/middle east/7918105.stm

Gaza: UN Official reports horrific hospital scenes of casualties. January 12, 2009 http://www. un.org/apps/news/story.asp?NewsID=29520\&Cr=gaza\&Cr1=unrwa

\section{Endnotes}

1 "Security Council overwhelmingly calls for immediate Gaza ceasefire." UN News Center. January 8, 2009. http://www.un.org/apps/news/story.asp?NewsID=29495\&Cr=gaza\&Cr1=

2 Ravid, Barak and Shamir, Shlomo. “Israel Rejects UN Truce Resolution." Haaretz Correspondents and New Agencies. January 10, 2009. http://www.haaretz.com/hasen/spages/1054201.html

3 Gaza: UN Official reports horrific hospital scenes of casualties. January 12, 2009 http://www. un.org/apps/news/story.asp?NewsID=29520\&Cr=gaza\&Cr1=unrwa

4 Maqbool, Aleem. "Scale of Gaza Destruction Emerges." January 19, 2009. http://news.bbc.co.uk/1/hi/world/middle east/7836869.stm

5 "Billions Pledged to Rebuild Gaza." BBC News Online. March 2, 2009. http://news.bbc.co.uk/1/hi/world/middle_east/7918105.stm

Haass, Richard and Indyk, Martin. "Beyond Iraq: A New U.S. Strategy for the Middle East." Foreign Affairs. January/February 2009.

7 Haass, Richard and Indyk, Martin. "Beyond Iraq: A New U.S. Strategy for the Middle East." Foreign Affairs. January/February 2009.

8 Hanelt, Christian-Peter. "After Gaza: A Common Dialogue Platform for the Middle East." Central and Eastern

European Online Library. Spotlight Europe, Issue: 02 / 2009, pgs: 18, www.ceeol.com.

9 Gause, Gregory III. "The Return of the Old Middle East: How to Win at Balance-of-Power Politics." March 12, 2009 http:// www.foreignaffairs.com/articles/64844/f-gregory-gause-iii/the-return-of-the-old-middle-east?page=show\#

10 "New Israeli Foreign Minister Dismisses Peace Effort." April 2, 2009.

http://www.nytimes.com/2009/04/02/world/middleeast/02mideast.html?_r=1\&scp=2\&sq=lieberman\&st=cse

11 Cordesman, Anthony. "The Gaza War: A Strategic Analysis." Center for Strategic and International Studies: Washington DC. February 2, 2009.

12 Haass, Richard and Indyk, Martin. "Beyond Iraq: A New U.S. Strategy for the Middle East." Foreign Affairs. January/February 2009

Photo Courtesy of:

Kai, Gin." Israeli Prime Minister Ehud Omert, left, President George W. Bush, and Palestinian President Mahmoud Abbas shake hands following President Bush's address." 27 November 2008 U.S. Navy. 6 April 2009.< http://www.navy.mil/view_single.asp?id=53143> 


\section{Aggressive Foreign Policy an Instrument for the Legitimization of Putin's Regime Georgia's Case}

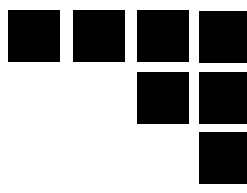

Professor Vladimir Shlapentokh

Professor of Sociology, Michigan State University

The responsibility of Georgian President Michael Saakashvili for the war with Russia continued to be hotly debated in Georgia, Russia and the world several months after its end. 'Indeed, there are various views about Saakashvili's decision to attack South Ossetia. By the end of the war, the international community was inclined to recognize the adventurous actions of the Georgian president, but put most of the blame on Moscow for its disproportionate reaction, its bombardment of Georgian cities, its permission to South Ossetian forces to plunder Georgians villages and kill Georgians, as well as its long occupation of Georgian territory. ${ }^{2}$

An Unprecedented Confrontation with the World

In fact, the Russian leaders, by crossing the Georgian borders and leaving their troops on the Georgian territory after the military hostility, showed that they are not afraid of antagonizing the world or becoming isolated internationally. As a pro-Kremlin Russian author stated in the aftermath of the war, "Moscow does not have allies today." As a matter of fact, no one ruler in Russian history dared to confront the world in such an uncompromising way as Putin did. Never during such a critical juncture was Russia supported by so few countries as is the case in this war. ${ }^{4}$ As noted by some Moscow analysts, the Soviet Union did not experience such a high level of global hostility after the invasion of Czechoslovakia in 1968 or the invasion of Afghanistan in 1979. ${ }^{5}$

It is remarkable that Russian official media, which did its best to present Moscow's behavior in the conflict in the most flattering way, could cite only Cuba, Venezuela, Mongolia and Syria as countries that endorsed the invasion of Georgia. However, none of these countries recognized the independence of South Ossetia and Abkhazia. By the end of January 2009, only Nicaragua, underscoring Russian isolation, recognized the independence of both entities, which was highlighted in Russian media. However, so far even the countries that supposedly maintain friendly relations with Russia are not in a hurry to show their support.

\section{Various Types of Reactions to International Isolation}

Only a few official journalists tried to simply deny or reduce the negative international reaction to "some aggressive forces" in the West. ${ }^{6}$ The leading reaction to the world's hostility was formulated directly by the Kremlin. First, it tried to downgrade the scale of the international opprobrium toward Moscow's actions. As Putin said in an interview with German TV, "Europe and the USA are not the whole world."7 Second, the Kremlin, particularly in the first weeks after the war, scoffed at the international condemnation, describing it as not at all dangerous to Russia. Even if the West was hostile, as Medvedev suggested, nothing dangerous could happen. $\mathrm{He}$ added, "We are not afraid of anything, including the prospect of a new Cold War." 8 In August and September, the official media was full of articles that mocked the possible sanctions against Russia, suggesting that it would damage the West more than Russia. ${ }^{9}$ With special gusto, politicians and journalists emphasized that the West, even Europe, is not united around a policy toward Russia-a fact, which, however, does not belie the evidence that even without direct sanctions Russia is 
poised to suffer a lot from the international opprobrium toward its actions, particularly in the modernization of its economy. ${ }^{10}$

\section{The Permanent Necessity of Legitimizing the Regime}

In fact, the real cause of the war and the developments that followed was neither Russia's concerns about security, the desire to protect Ossetians from "genocide" nor Russian citizens in the Caucasus. The maintenance of its authoritative regime was the Kremlin's prime purpose when it reacted to the Georgian attack and confronted the world.

The existing regime, like any authoritarian regime in the contemporary world, despite the high rating of Putin, is in permanent fear of its shaky legitimization (the last presidential election was not seriously defended by anybody in Russia including the loyalists). One of the main reasons for Putin's hatred of Ukraine and Georgia is that presidents Yushchenko and Saakashvili went back to the "Orange Revolutions" in their countries in 2003-2004. In the aftermath of these revolutions, the Kremlin was in a state of panic, with a new fear, if mostly unfounded, that the "orange disease" would spread to Russia. For almost three years, the media lambasted Kiev and Tbilisi, declaring that the developments there were organized by the West. ${ }^{11}$ The idea of "sovereign democracy," which was invented to justify the authoritarian regime, was born at this time. What is more, with its concerns about a Russian Orange Revolution, the Kremlin

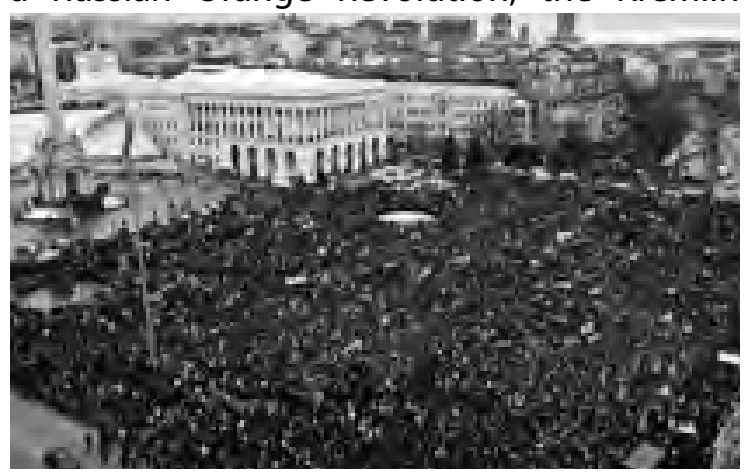

Thousands of demonstrators protest in Kiev's Independence Square during the Orange Revolution November 2004. created several big youth organizations, such as "Ours," which were officially ready to enter street battles against the opposition.

The Kremlin's fear of an Orange Revolution subsided by 2007. However, Putin and his friends, with the country still under their total control, are deeply concerned about the emergence of a real opposition. The Kremlin panics at the first sign of even a weak opposition. The top elite are afraid that a mild opposition may threaten its rule and property. Even an anti-governmental demonstration, with a few hundred participants in Moscow or Petersburg, is treated as a great emergency, which prompts the leadership to mobilize special riot units, as if the crowd is planning to march on the Kremlin. The black list of people who are banned from making appearances on TV has been increasing because even the most humble critics of the regime became "enemies of the people." Former Prime Minister Mikhail Kasianov, himself a member of the establishment, was immediately ostracized and removed from the presidential election campaign in the beginning of 2008 as soon as he declared his opposition to the regime. Even Mikhail Khodorkovsky is perceived by the Kremlin as a danger to the regime. In August 2008, the Kremlin refused to parole him after five years in prison, despite the pressures from public opinion inside and outside the country and against the expectation of even loyal journalists. Putin sees him as a potentially successful opposition leader. ${ }^{12}$

Putin's regime, like any authoritarian regime, needs to legitimize its existence in the eyes of the people. The Soviet regimes, which were much stronger politically than that of Putin, needed a permanent ideological underpinning to sustain its legitimacy in the country. The regular ideological campaigns were a fixture of Soviet society at each stage of its history.

The legitimization of the regime is accomplished with "positive" and "negative" propaganda. The role of negative propaganda, with its focus on foreign and domestic 
enemies, was extremely high in Stalin's time, but positive propaganda (the achievements of the country in economy, education, science and the arts) still played an important role. In Stalin's last report to the party congress (1939), negative propaganda (diatribes against foreign and domestic enemies) took up less than 10 percent of the text. ${ }^{13}$

The role of enemies in the postStalin period declined significantly and the Soviet leaders and media focused on the great achievements of the country in various spheres of life. Only 15 percent of Andropov's biggest speech as the leader of the country (he was known as the most belligerent leader after Stalin) was about foreign enemies. ${ }^{14}$ The Soviet leaders could indeed boast about the great successes in the building of new factories and railroads, about the pioneering achievements in science and space research, and about the successes in culture and education. In order to persuade the people about the legitimacy of the Communist Party and its leaders, they could indeed rely mostly on "positive" propaganda.

During Putin's first term, the Kremlin had enough positive arguments to legitimize the regime. The contrast with the 1990s provided them with the possibility of focusing on the stability of society, on the regular payment of salaries and pensions, and on the rise in the standard of living. In Putin's second term, these arguments no longer worked. He could not use elements of life that were taken for granted in any society as propaganda. Putin needed achievements in the economy, science and culture, which the regime could not supply. His regime could not boast about even one big economic or technological achievement. There were no new large factories, no successes in science and space, and no successes in health services or demography. Even the production of gas, the backbone of the economy, has not grown since 1999. ${ }^{15}$

For this reason, the Kremlin did not want to miss any opportunity, even ridiculous ones, to boast of its success and prompt patriotism. The victory of the Russian football team over the Dutch team in a European competition in June 2008 was turned into a great national festivity, with millions of Muscovites celebrating the victory as if it was a Kremlin achievement (the Russian team ended up in third place). ${ }^{16}$ The national jubilation over a rock singer's first prize in an amateurish music festival (Eurovideo) in May 2008 (the singer was congratulated by both Russian leaders ${ }^{17}$ ) was another example of the Kremlin's desperate quest for arousing a patriotic frenzy. ${ }^{18}$ Given the lack of opportunities to bolster the regime with its successes, the Kremlin only had one choice: increase the role of negative propaganda and focus on enemies.

Indeed, the relative roles of negative and positive propaganda in Brezhnev's and Putin's times were different. Compare, for instance, an issue of Izvestiia published on September 8, 2008 to the September 8, 1980 issue. In the 2008 issue, which contained 40 articles, not even one was on economic or scholarly success. Six articles talked about various problems in the economy; 14 articles talked about various enemies. The rest were about cultural and sporting events. In the 1980 issue, which included 49 articles, 19 talked about economic achievements, 6 articles were about foreign enemies, 11 articles discussed friends abroad (such materials were totally absent 28 years later), and the remaining articles were about cultural and sporting events.

\section{A Shift in Mindset: Oil Revenues and a Revolution in the Kremlin}

The important question is not why this shift in foreign policy happened, but why it did not occur several years earlier, when Putin came to power with his slogan about restoring the country's geopolitical role in the world and reestablishing its control over the former Soviet republics. In fact, until 2006, Putin restrained, to some extent, the impact of the imperial ideology and anti-Americanism on real politics. He even made several moves 
in favor of the United States, including his offer of cooperation with America in the fight against terrorism.

We can almost identify the exact time when the rise in the price of oil and oil revenues reached a level that suddenly changed Putin's mind and gave him the confidence to raise Russia "from its knees" (a phrase that has become a fixture in the country's political lexicon). The price of oil had been increasing throughout Putin's presidency, but in 2005 he seemingly concluded that the torrent of petrodollars had reached a level that could radically change foreign policy and give a new boost to the imperial mood in the country. On December 22, 2005, at a meeting of the Russian Security Council, Putin proclaimed that Russia was back on top and playing a key role on the world stage. At this moment, Putin's oil pride spread to the ruling class. The idea that the country could now dictate its will to the world, or at least to European countries, without speaking of former Soviet republics, such as Ukraine, Georgia and Belorussia, became a major slogan in the Kremlin's propaganda, just as victory in war and Sputnik had been the centerpieces of Stalin's and Khrushchev's propaganda, respectively. The magic power of oil became a major source of inspiration for imperial and nationalistic feelings. Dmitry Medvedev, the first deputy prime minister and the future heir to Putin, in a rare political interview in July, devoted twothirds of his talk to describing how oil and gas had strengthened the country. ${ }^{19}$

\section{The Further Development of the Dutch Disease: Contempt for America}

With the growing influx of money to Russia, the Kremlin began to release itself from a deeply entrenched acceptance of the United States as a country with a much stronger economy and military. In the past (whatever the Russians' views of America) the United States was recognized as a powerful country with the biggest and most efficient economy in the world and a well-organized state machine.
There were periods (if to consider history after 1917) when Moscow held very positive attitudes toward the United States: adoration in the 1920s, high respect during the war, and friendliness in the second half of the 1980s and the first half of the 1990s. We can also see periods of deep hostility toward the United States: hatred in the late 1940s and early 1950s, moderate enmity in the 1960s and 1970s, high hostility in the early 1980s, and mistrust between the mid 1990s and 2007. Even if the intensity of the anti-American propaganda varied in the postwar period, one feature was typical for all Soviet regimes: the Soviet Union was economically and technologically behind the United States. This thesis was essential not only in the closed, or internal, party ideology, which was addressed to the nomenklatura through mostly secret channels of communication, but also, to some degree, in the open ideology. Praising the numerous advantages of the Soviet system over the Western one, the Soviet textbooks recognized that technologically the USSR was still behind the West. In fact, Gorbachev's ascension to power was a direct result of the belief in the Politburo that Reagan's Star Wars project would make the technological superiority of the United States over the USSR incompatible with the survival of the USSR as a superpower. In each of these periods, the United States was recognized as powerful.

However, by 2008, a new type of attitude crystallized that was practically unknown in Russia. The jump in oil revenues, along with a new ability to blackmail Europe with its supply of fuel, gave Putin a new selfconfidence and arrogance. The oil intoxication changed the minds of the Kremlin on many issues. The Kremlin leader and the whole elite suddenly began to feel superior over the world, the United States and Europe in the first place. The various economic difficulties that the United States experienced in 2006-2008 helped convince the Kremlin that America is no longer a superpower. Putin and the elite were not confused at all by the fact that, 
besides oil revenues and the ability to turn off the gas pipelines, nothing happened in Russia that made it economically, technologically or militarily stronger than it was before 2005. The new image of America held by the Russian leader and his circle was conveyed to the elite and the general public. It was accepted with joy by everybody who was in line with the Kremlin, felt nostalgia for the empire and saw the United States as the major culprit of the country's humiliation in the 1990 s.

The elite's frontal attack against America as a society (media have been doing it for a long time, particularly since 2000) was

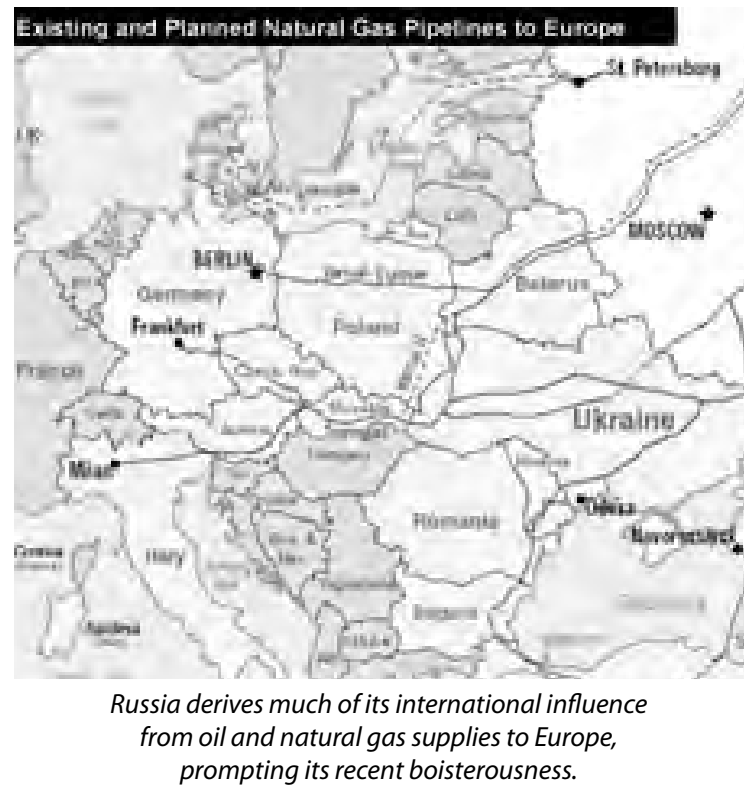

started, of course, by Putin himself. In his Munich speech in February 2007, which was deeply anti-American, he talked for the first time, with weakly veiled contempt, about those "who teach us democracy but do not want to learn it themselves" (he clearly had the United States in mind). He mocked the United States, which has gone from one conflict to another without achieving a full-fledged solution to any of them. ${ }^{20}$

In the last two years, Russian media denigrated America as a weak country, with a failing economy, stupid people and cynical leaders, which is doomed to collapse. A few days before the Georgian war, the Kremlin considered it necessary, via a high-level Russian diplomat, to explain to the world what it thinks about the United States. He told a leading Russian newspaper that "the collapse of America is unavoidable." Developing his view, this high official of the Ministry of Foreign Affairs suggested that now Russia can "afford to not have any relations with the USA." ${ }^{21}$ In an unprecedented way, President Medvedev rebuked America as a country that "lives beyond its means," and suggested that the American president should "find out what is going on with the American economy" instead of meddling in foreign affairs. ${ }^{22}$

Not only those who served the Kremlin, but even many liberals who were critical of Putin joined the chorus of those who taunted and ridiculed America. Yulia Kalinina, a brave critic of Putin's regime, is convinced about "the degradation of the management system in the United States."23 Another famous liberal, economist Alexander Lifshitz, suggested that any respect for the American experience in the economy is gone. ${ }^{24}$ Downgrading the might of America, Moscow is unique even among the greatest haters of the United States. Chavez continues to describe America as a dangerous monster and an "empire" that is able to take control over Latin America. 25

\section{Russia's Greedy Elite: A Chance to Stop the Deterioration}

In using the imperial ideology and aggressive foreign policy, the Kremlin is concerned not only about public support. The loyalty of the elite is of special importance to the Kremlin. The absolute majority of the elite is politically passive and do not participate in the decision making process in the Kremlin. At best they can play the role of advisers. However, the Kremlin is deeply concerned about the loyalty of "the passive elite," because its members help to maintain the regime, control the army and the FSB, and run public propaganda. The elite includes most of the state apparatchiks at high levels, the FSB and military commanders, the members of the parliament, and leading 
media figures - a group that includes no more than 1,000 to 1,500 people.

Most members of the elite clearly enjoy the patriotic ecstasy along with ordinary people. They are happy with the Kremlin's antidemocratic actions, since only the authoritarian regime is able to guarantee their privileges and preserve their illegal fortunes. At the same time, many members of the elite are rather critical of the rude confrontation with the West. We can speculate, following the view of the famous Moscow journalists Yulia Kalinina and Andrei Riabov, that the elite, given their close material ties to the West (a Russian journalist referred to them contemptuously as the "offshore elite" ${ }^{\text {"26) }}$ are sizzling with repressed anger against the Kremlin's policy. These people, as Kalinina writes, not without irony, are afraid to be cut off from their "honestly acquired villas in Spain, mountain ski resorts in France, yachts in the Mediterranean, and London boutiques."27 These people already, in various ways, feel the consequences of the West's animosity toward Moscow's policy. A pro-governmental journalist described in Izvestiia how unfriendly London became toward Russian travelers after the war. ${ }^{28}$

The ability of the critical members of the elite, who hide their views from the public and perhaps even from friends, to encourage the Kremlin to change its harsh anti-Western position without endangering their positions is very limited. Only under propitious circumstances can they persuade the Kremlin, using the personal interests of Putin and his circle as an argument, to move politics in a different direction.

We can only guess what was going on behind the Kremlin walls in the last weeks of September and what persuaded Putin and his partner in power to relent, somewhat, in their aggressive tone against Europe. They continued, however, as Medvedev's speech in Evian (October 8) showed, to lambast the United States as the major villain, accountable for all evils in the world, economic and political. ${ }^{29}$ Both leaders started inviting foreign media experts for various meetings, during which they tried to soften their position and presented Russia as a pure victim of the crazy Georgian president. $^{30}$ The Kremlin showed its delight as it hosted foreign dignitaries, including the Spanish and German prime ministers. With special fervor, the Kremlin tried to foment, as Brezhnev did in the 1970s, the discord between the United States and Europe, and demonstrated good relations with Sarkozy.

The Kremlin does not miss an opportunity to declare that a new Cold War is impossible, which contrasts with what they said a few weeks before. Downgrading the shrill anti-Western tone in their propaganda, the Kremlin has not, however, retreated from its position of confrontation with the world, which is important for perpetuating its deeply antidemocratic regime. The big injection of anti-Americanism during the war will affect the minds of Russians for a long time.

\section{The Drop in Oil prices and Changes in Moscow}

In view of the crucial role of high oil prices in Putin's domestic and international policy, as discussed above, the sudden fall in prices, along with the economic and financial crisis, had an enormous impact on the Kremlin. The shift from complacency in the aftermath of the war with Georgia to apprehension occurred in October. The Kremlin felt the tremors of danger only when it discovered the negative impact of the war on its economy. The catastrophic decline in the value of its stock market and the flight of capital started before Russia began to feel the influence of the growing world financial crisis, which multiplied the troubles in the financial markets. By mid October, the value of Russian stocks fell by 70 percent in comparison with early May. ${ }^{31}$ However, it was the fall of oil prices and other raw materials that delivered the most painful blow to the regime. Indeed, oil prices fell from $\$ 145$ to $\$ 34$ per barrel at the end of December. 
Meanwhile, raw materials made up 80 percent of the export revenues and one third of the budget. ${ }^{32}$ The fall in the value of the ruble against the dollar was also very painful for millions of Russians who kept their savings in national currency. The Kremlin toned down somewhat its aggressive propaganda against the West and even against Georgia. For instance, Moscow resumed its issuing of entry visas to Georgian citizens. ${ }^{33}$ Even during the gas war with Ukraine, during which Russia tried to show its strength, Moscow behaved relatively calmly. However, only a few observers believe that the fall of oil prices could radically change Putin's aggressive foreign policy so important for him for ideological reasons.

\section{Conclusion}

The West should be prepared to deal with an authoritarian regime that is ready to do anything to protect itself against its internal enemies. The Kremlin will continue to need foreign enemies. It will also remain prone to show the Russian public its success in confronting its neighbors and the United States. As a liberal journalist suggested, Russia became "an unpredictable state," which "can defy its own international obligations." ${ }^{34}$ The world can only hope that, with the lessons from the war against Georgia, the Kremlin will be more cautious when it looks for a new opportunity to show its imperial ambitions.

\section{Endnotes}

1 Matt Siegel, "Saakashvili denies ex-diplomat's claims," Associated Press, November 28, 2008.

2 See the report of Human Rights Watch in The New York Times, January 24, 2009.

Georgii Bovt, "Ofshornaia aristokratiia vse profukaiet?" Izvestiia, August 21, 2008.

Fedor Luk'ianov, "Seven theses prompted by the Russia-Georgia conflict," RFE/RL, August 26, 2008.

See, for instance, the interview of Leonid Radzikhovskii with Ekho Moskvy on August 22, 2008.

No Author, "Ne ochen' "kholodnaia voina," Rossiiskie Vesti, August 20, 2008.

See Vladimir Putin's interview in Lenta.ru, August 30, 2008.

Maksim Bashkeev, "Prezidentskii otvet," Tribuna, August 28, 2008.

Anna Kaledina and Sergei Leskov, “Ot chego Rossiia mozhet izolirovat' Zapad?" Izvestiia, August 26, 2008.

10 Liliia Shevtsova, "Konets epokhi: Logika osazhdennoi kreposti," Vedomosti, September 24, 2008.

11 Vladislav Surkov, "Suverenitet - eto politicheskii sinonim konkurentosposobnosti," Moskovskie Novosti, March 10, 2006.

12 See the interview of Kungarkin, the editor of the pro-Kremlin Komsomol'skaia Pravda, with Ekho Moskvy, August 20, 2008.

13 Iosif Stalin, Voprosy Leninizma, Moscow: Gospolitizdat, 1952, pp. 603-650.

14 Yurii Andropov, Izbrannyie rechi i stat'i, Moscow: Politizdat, 1983, pp. 209-218.

15 Vladimir Milov and Boris Nemtsov, "Putin i 'Gazprom'," Novaia Gazeta, August 31, 2008

16 Sergei Leskov, "Mozhet, my i vsiu Rossiiu sumeem vyvesti v sploshnoi "Zenit”?" Izvestiia, May 16, 2008.

17 Natal'ia Malakhova, "Bilan v "zenite," Novaia Gazeta, May 29, 2008.

18 Artur Gasparian, "Russia, Hello!" Moskovskii Komsomolets, May 30, 2008

19 Stanislav Tarasov, "Natsional'nyi interes. Velikaia “vosmerka'," Rossiiskie Vesti, July 19, 2006

20 See Putin's speech at the Munich Conference on Security at http://www.securityconference.de/

konferenzen/rede.php?sprache=en\&id=179, accessed September 30, 2008.

21 No author, "Moskva - Washingtonu: ne uchite nas s kem druzhit' i s kem spat'," Izvestiia, July 30, 2008.

22 Dmitry Medvedev, "Zaiavlenie i otvety na voprosy zhurnalistov na press-konferentsii po itogam rossiisko-ispanskikh peregovorov, October 1, 2008 (available at http://kremlin.ru/appears/2008/10/01/2140_type63377type63380_207123.shtml, accessed October 3, 2008).

23 Yuliia Kalinina, "Gruzinskaia mama protiv rossiiskogo papy," Moskovskii Komsomolets, September 4, 2008.

24 Alexander Lifshits, "Yesterday," Izvestiia, August 6, 2008.

25 See, for instance, Hugo Chavez's speeches in Diario Vea, July 3, 2008, and in Diario Las Últimas Noticias, August $29,2008$.

26 Georgii Bovt, "Ofshornaia aristokratiia" vse profukaiet?" Izvestiia, August 21, 2008.

27 Yuliia Kalinina, "Chem otvetit Zapad," Moskovskii Komsomolets, August 29, 2008; Andrei Riabov, "Pobeda ne prikhodit odna," Novaia Gazeta, September 14, 2008.

28 Mikhail Ozerov, "“Medvedia' - na golodnyi paek," Izvestiia, September 16, 2008.

29 Dmitry Medvedev, "Vystuplenie na konferentsii po mirovoi politike," October 8, 2008 (available at http://www.kremlin. ru/appears/2008/10/08/1619_type63374type63377type82634_207422.shtml, accessed October 10, 2008).

30 See Dmitry Medvedev's press-conference speech, "Sovmestnaia press-konferentsiia s Federal'nym kantslerom Germanii Angeloi Merkel' po itogam rossiisko-germanskikh mezhgosudarstvennykh konsul'tatsii," October 2, 2008 (available at http:// www.kremlin.ru/appears/2008/10/02/2156_type63377type63380_207176.shtml, accessed October 10, 2008).

31 Segei Kulikov, "Glubina padeniia. Pochemu birzhi v Rossii upali v dva-tri raza sil'nee, chem v drugikh stranakh," Nezavisimaia Gazata, October 10, 2008; No author, "Rossiiskie aktsii padaiut vsled za vsem mirom," IFX.RU, December 12, 2008, available at http://www.ifx.ru/txt.asp?rbr=1494\&id=1031322, accessed December 10, 2008.

32 Federal'naia Sluzhba Gosudarstvennoi Statistiki, Rossiiskii Statisticheskii Ezhegodnik, 2007, Moscow: Rosstat, 2007, p. 756; Dmitrii Polonskii, "Minekonomiki nedootsenilo obval," Den'gi, December 15, 2008.

33 Ol'ga Allenova, "Rossiia vozobnovliaet postavki viz v Gruziiu," Kommersant. Daily, January 20, 2009.

34 Dmitry Oreshkin's interview with Moskovskii Komsomolets, September 2, 2008.

Photos Courtesy of:

"Protest in Independence Square."Wikipeadia. 6 April 2009.< http://en.wikipedia.org/wiki/Orange_Revolution>

"Natural Gas Pipeline Map."Wikipeadia. 6 April 2009.< http://en.wikipedia.org/wiki/File:RUGasPipesMap.jpg> 


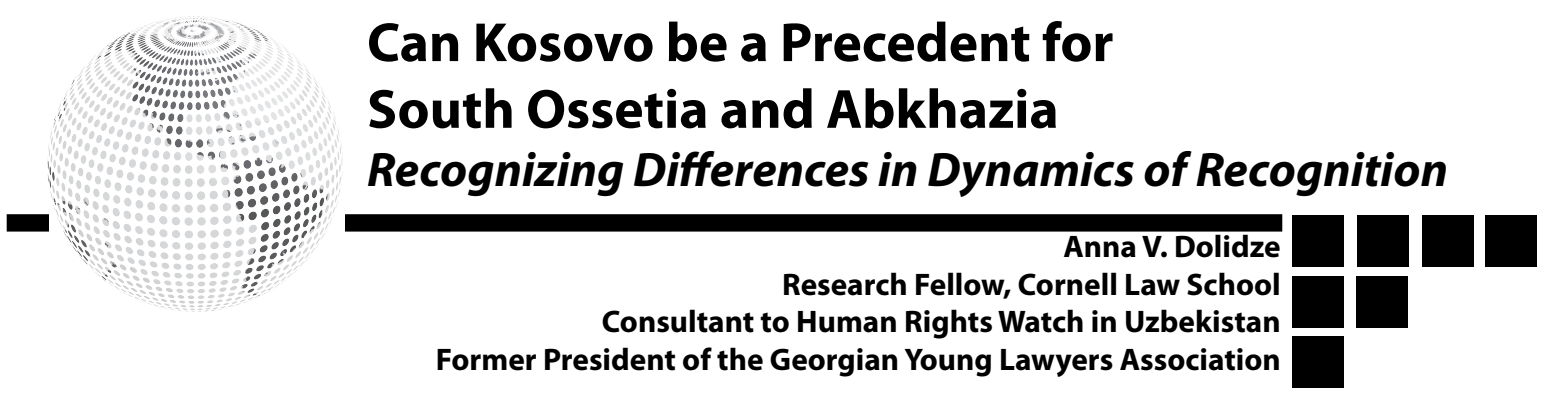

The issue of whether the recognition of Kosovo as an independent state might serve as a precedent for former autonomous republics of Georgia, South Ossetia and Abkhazia has been often debated. This paper aims at comparing the processes of recognition of these three entities. It illustrates that the international community has been gradually recognizing Kosovo as a State while South Ossetia/Abkhazia have been subjected to the policy of non-recognition. It argues that because the dynamics of recognition of Kosovo and South Ossetia/Abkhazia have been very different, it is less likely that the establishment of Kosovo as a viable state will serve as a precedent for South Ossetia/ Abkhazia.

Although the secession of Kosovo from FRY and of South Ossetia/Abkhazia from Georgia has been studied in many respects, the character of the recognition process of the three entities has hardly been compared. But the question arises - is it at all worthwhile to compare who have recognized Kosovo and South Ossetia/Abkhazia and if so, what could we learn from such comparison?

Answers to these questions lie, first of all, in the importance of principles involved in the recognition of states under international law.

Recognition has served international society as a device by which to respond to changes in world public order and the emergences of new states. ${ }^{3}$ Hence, as we have witnessed the disintegration of two multiethnic states in the last two decades, the USSR and FRY, recognition has acquired renewed importance.

One of the most prominent debates in the international law of recognition, i.e. the branch of international law that determines the existence of the state, is a debate between constitutive and declaratory schools of recognition. Scholars aligning themselves with the constitutive theory claim that an entity requires recognition by other States to be endowed with international legal personality. While the declaratory school maintains that a political community meeting the requirements of statehood provided in the Montevideo Convention ${ }^{4}$ automatically qualifies as a "State" and that recognition by other States simply acknowledges (declares) "as a fact something which has hitherto been uncertain." ${ }^{15}$

It is established, however, that the declaratory doctrine has exercised greater attraction than Constitutivism over the last thirty years. ${ }^{6}$ Yet, even to those that share prevalence of declaratory doctrine, recognition by other states remains important. ${ }^{7}$ For example although the Supreme Court of Canada, discussing the legality of possible secession by Quebec in Canada, ${ }^{8}$ adopted the declaratory theory of recognition, it emphasized "the viability of a would-be state in the international community depends, as a practical matter, upon recognition by other states." 9

Collective recognition in the form of acceptanceto the United Nations, and toalesser extent to other international organizations, and recognition by other international organizations, as in the case of recognition by EC of Croatia and Bosnia in 1992, may impact upon the whole question of statehood..$^{10}$ Some scholars have argued that there is a shift under way from individual recognition by states to collective recognition through international organizations. ${ }^{11}$ However, the dynamics of recognizing Kosovo, the most recent exercise 
in recognition of a new State, attests to the contrary.

Recognition of Kosovo was a highly individualized affair among states. Kosovo declared its independence on February 17 2008. ${ }^{12}$ The United States of America was the first country to formally recognize Kosovo as a sovereign and independent state on February 18 2008. ${ }^{13}$ The European Union deferred the question to its individual members. ${ }^{14}$ While France, Germany, Italy and the other 20 members of EU individually recognized Kosovo as an independent state, ${ }^{15}$ Spain refused to recognize Kosovo's independence as "it does not respect international law."16 Similarly, Cyprus, Greece, Romania, Bulgaria and Slovakia have rejected Kosovo's independence. ${ }^{17}$

As Maldives became the $55^{\text {th }}$ country to recognize the independence of Kosovo, the opinion of Russian Federation that Kosovo stays an indivisible part of Serbia remains unchanged. ${ }^{18}$ In line with position of other former USSR countries troubled with secessionist conflicts Moldova, Azerbaijan, Ukraine, Georgia also refrained from recognizing Kosovo.

The United Nations has not had a chance to pronounce on Kosovo's statehood because Kosovo has not applied for UN membership as Russia is threatening to use its seat in the UN Security Council to block Kosovo's membership application. ${ }^{19}$ Having being asked to admit Kosovo as a member on July 10 2008, the World Bank and IMF are still silent on the issue although the typical time limit for considering such applications is soon to expire. ${ }^{20}$

The above-stated chronology of Kosovo's recognition by individual states and inability or unwillingness of international organizations to be at the forefront of this process signifies that the process of Kosovo's recognition was decentralized among individual countries and, contrary to what some scholars suggest, collective recognition did not play a role.

The situation with recognition of
South Ossetia is different. Coordination among international organizations on the non-recognition of South Ossetia/Abkhazia resembles the process of non-recognition thus reducing minimally the possibility of these entities to be established as independent and viable states.

The first clear-cut case of nonrecognition took place in the 1930s with respect to a state of "Manchukuo" -- the former Manchuria-- which Japan took over from China in 1931 and where a formal "head of state" was installed by Japan after the takeover. Although some individual states, notably EI Salvador, Poland, Hungary, Spain and Italy, did recognize Manchukuo, ${ }^{21}$ the League of Nations refused to do so, specifically declaring that "it is incumbent upon the Members of the League of Nations not to recognize any situation, treaty or agreement which may be brought about by means contrary to the Covenant of the League of Nations and to the Pact of Paris." 22

There are a number of precedents where the League of Nations and the United Nations openly urged for non-recognition of aspirant states, including secession of Katanga from the Republic of Congo in 1960, the case of Southern Rhodesia from 1965-1980, secession attempts of South Africa's states of Transkei, Bophutgatswana, Venda and Ciskei, etc. The non-recognition of the Turkish Republic of Northern Cyprus by the United Nations is a more recent example.

Following a military coup by Greek officers which called into question the internationally guaranteed constitutional framework of Cyprus, Turkey sent in troops on 20 July 1974 and occupied the northern part of the island. Although the intervention was clearly aimed at supporting the Turkish minority, it was only on 15 November 1983 that the "Turkish Republic of Northern Cyprus" was proclaimed. Both the invasion and the declaration ofindependencewereimmediately denounced by the UN Security Council as a violation of the sovereignty of the Republic of 
Cyprus and as an invalid attempt to create a new state. ${ }^{23}$ Security Council Resolution 541 expressly deplored "[...] the declaration of the Turkish Cypriot authorities of the purported secession of part of the Republic of Cyprus" and called "[...] upon all States not to recognize any Cypriot State other than the republic of Cyprus." ${ }^{24}$ TRNC has been recognized only by Turkey.

Former Autonomous Republics of Georgia, Abkhazia ${ }^{25}$ and South Ossetia ${ }^{26}$ declared independence after secessionist conflicts with Georgian forces ${ }^{27}$ where secessionist troops were largely aided and backed by Russia. ${ }^{28}$ Russian troops invaded the territory of Georgia in August 2008, justifying the action by defense of South Ossetia's population from Georgian aggression, and have announced plans to establish permanent military bases on the territory of South Ossetia. ${ }^{29}$ South Ossetia (together with a secessionist republic of Abkhazia) was recognized by the Russian Federation on August $262008 .^{30}$ Although Belarus and Venezuela were supporters of Russia's recent intervention in Georgia, only Nicaragua ${ }^{31}$ so far has joined Russia in recognizing the two secessionist entities.

International organizations have been engaged in the collective policy of nonrecognition of statehood of South Ossetia and Abkhazia. According to Hersh Lauterpacht "non-recognition is based on the view that acts contrary to international law are invalid and cannot become a source of legal rights for the wrongdoer. That view applies to international law as one of the "general principles of law recognized by civilized nations." 32 The list of decisions by international organizations confirming the territorial integrity of Georgia and urging non-recognition of the two entities is boundless. Due to Russia's veto, the Security Council of the United Nations could not arrive at a condemning resolution but the $\mathrm{EU}^{33}, \mathrm{NATO}^{34}$ Chairman of OSCE ${ }^{35}$, and Council of Europe $^{36}$ have all reaffirmed support for Georgia's territorial integrity, condemned recognition by Russia of two secessionist entities and called upon withdrawal of this decision. It is evident that the international community has implemented a policy of nonrecognition vis-à-vis South Ossetia/Abkhazia.

Overview of practice of recognition of Kosovo and South Ossetia/Abkhazia illustrates that the three entities have gone on two different paths. Kosovo was gradually and individually recognized by more than fifty states while the international community extended a policy of non-recognition with respect to South Ossetia/Abkhazia. Therefore, it could hardly be claimed that in this respect the case of Kosovo represents a precedent for statehood of South Ossetia and Abkhazia.

\section{Endnotes}

1 Interview of the De Facto President of South Ossetia Eduard Kokoity, March 05, 2008, available at http://www.rferl.org/content/article/1079593. html; President of the Russian Federation Vladimir Putin, February 1, 2006, http://www.rferl.org; South Ossetia Is Not Kosovo, The Economist, August 28 2008, available at http://www.economist.com/opinion/displaystory.cfm?story_id=12009678; Christopher Hitchens, South Ossetia Isn't Kosovo, August 18, 2008, available at http://www.slate.com; Zeyno Baran, Thomas de Waal, Abkhazia-Georgia, Kosovo-Serbia, Parallel Worlds? August 01, 2006, available at http://www.opendemocracy.net/democracy-caucasus/abkhazia serbia 3787.jsp, retrieved on Ferbuary 20, 2009

2 In 1936, the Institute of International Law defined recognition as "[...] the free act by which one or more States acknowledge the existence on a definite territory of a human society politically organized independent of any other existing state, and capable of observing the obligations of international law, and by which they manifest therefore their intention to consider it a member of the international community." (1936) 30 AJIL Supplement 185.

3 Thomas Grant, THE RECOGNITION OF STATES. LAW AND PRACTICE IN DEBATE AND EVOLUTION, Westport, Connecticut 1999.

4 Article 1 of the Montevideo Convention on the Rights and Duties of States provides an oversimplified list of criteria for statehood: a permanent population, a defined territory, a government and a capacity to enter into relations with other States, 165 L.N.T.S 19.

5 John Dugard, ReCognition AND the UnItEd NATIONS, Cambridge Grotius Publications Limited 1987. pp.7.

6 Thomas Grant, supra note 3 at 19; see also James L. Brierly, The Law of Nations: An Introduction to the International LaW of PeACE, Sir Humphrey Waldock Ed., $6^{\text {th }}$ ed. (Oxford. Clarendon Press, 1963), p. 139; lan Brownlie, Principles of Public INTERnAtIONAL LAW, $3^{\text {rd }}$ ed. (Oxford: Clarendon Press, 1979) p. 90-91; D.J. Harris, and perhaps for the most comprehensive defense of the declaratory doctrine, Ti-Chiang Chen, THE INTERNATIONAL LAW OF RECOGNITION, WITH SPECIAL Reference to Practice in Great Britain and the United States, London: Stevens \& Sons Limited, 1951.

7 In general, see John Dotard, Recognition And the United Nations, Cambridge Grotius Publications Limited 1987.

820 August 1998 Advisory Opinion of the Supreme Court of Canada Reference Re: Secession of Quebec, [1998] 2 S.C.R.217; 37 ILM 1998, 1342.

9 Id. at 142.

10 Malcolm Shaw, The Role of Recognition and Non-Recognition with Respect to Secession: Notes on Some Relevant Issues, in SECESSION IN INTERNATIONAL LAW, Julie Dahlitz ed., TMC Asser Press 2003, p. 251-252. 
11 Hersh Lauterpacht, RECognition In INTERNATIONAL LAw (Cambridge: The University Press, 1948), documented several cases of collective recognition of states: recognition of Greece by the Treaty of London of 1830; of Belgium by the Treaty of London, 1831; of Bulgaria, Serbia, Montenegro and Romania by the Berlin Treaty of 1838; of the Congo State by the Berlin Treaty of 1885; of Albania by the Conference of London in 1913; of Poland, Lithuania, Latvia and Estonia by the Allies after World War I and of the States of Latin America by the joint action urged by the Great Britain at the Congress of Verona in 1823; Malcolm Shaw, id at 253.

12 Declaration of Independence adopted by Kosovo's Parliament on February 17 2008, available at http://www.assembly-kosova.org/common/docs/ proc/trans s $2008 \quad 02 \quad 17$ al.pdf, retrieved on December 10, 2008.

13 U.S. Department of State, http://www.state.gov/p/eur/ci/kv/c24701.htm, retrieved on March 1, 2009.

14 Slovenian Presidency of the Council of the European Union, Special Permanent Council \#702, EU Statement in Response to the Serbian Foreign Minister, H.E. Mr. Vuk Jeremic, February 19, 2008, available at http://www.osce.org/documents/pc/2008/02/29784 en.pdf.

15 See http://news.bbc.co.uk/2/hi/europe/6386467.stm.

16 Spanish Foreign Minister Miguel Angel Moratinos quoted in http://www.time.com/time/world/article/0,8599,1714413,00.html on February 19, 2008, retrieved on February 20, 2009.

17 See http://www.dw-world.de/dw/article/0,2144,3132996,00.html, retrieved on February 22, 2009.

18 Foreign Minister of Russia Sergei Lavrov quoted by Ria Novosti News Agency on February 20, 2009 at http://en.rian.ru/russia/20090220/120237609. html, retrieved on March 1, 2009.

19 Russian Foreign Minister Sergei Lavrov quoted by Voice of America News Service, April 2, 2008, available at http://www.voanews.com/english/ archive/2008-04/2008-04-02-voa39.cfm?CFID=130742664\&CFTOKEN=15656435\&jsessionid=883034d17e6c0d04ee5b507e6e1873577a31. According to Article 4(2) of the UN Charter, "The admission of any such state to membership in the United Nations will be effected by a decision of the General Assembly upon the recommendation of the Security Council."

20 Statement on the Membership of the Republic of Kosovo in the IMF, July 15, 2008, available at http://www.imf.org/external/np/sec/pr/2008/pr08179. htm, retrieved on February 24 2009; UN membership is not necessary for the membership in the World Bank group but membership to the IMF is, see Article 1(B) Article of Agreement of the International Bank for Reconstruction and Development; The World Bank group stated that the application will be processed in coordination with the International Monetary Fund, where an application has also been filed. The membership process typically takes a minimum of 6 to 9 months, see

http://web.worldbank.org/WBSITE/EXTERNAL/NEWS/0, contentMDK:21842154 pagePK:34370 piPK:34424 theSitePK:4607,00.html; Section 21 of the By-Laws of the International Monetary Fund states that "a) any country may apply for membership in the fund by filing with the Fund an application, which shall set forth all relevant facts". By-Laws do not set a specific time-limit for considering applications for membership instead indicating that "the application shall be placed promptly before the Executive Board, and a reasonable time shall be allowed for discussion and preliminary investigation by the Executive Board before a decision is reached to proceed with the formal investigation." See D-1 By-Laws of the IMF; Similarly, Article 2 Section 2 of Articles of Agreement of the IMF states, "Membership shall be open to other countries at such times and in accordance with such terms as may be prescribed by the Board of Governors"; both available at http://www.imf.org.

21 Thomas Grant, supra note 3 at.131.

22 League of Nations Official Journal, March 1932, Special Supplement No. 101, p. 87; for an extensive discussion of this decision as well as the analysis of collective recognition and non-recognition under international law see John Dugard, RECOGNITION AND THE UNITED NATIONS, Cambridge Grotius Publications Limited 1987.

23 Georg Nolte, Secession and External Intervention in Secession: International Law Perspectives, Marcelo G. Kohen ed., Cambridge University Press 2006 at 77.

24 Security Council Resolution 541, November 18, 1983.

25 The de facto Parliament of Abkhazia adopted a unilateral declaration of sovereignty on July 23, 1992.

26 South Ossetia adopted its declaration of independence on September 20, 1990.

27 See Zurab Burduli and Anna Dolidze, Housing and Property Restitution in the Republic of Georgia in: RetUrning Home: Housing ANd Property Restitution Rights of Refugee and Displaced Persons, Scott Leckie ed., Transnational Publishers 2003; see also Bruno Coppieters, War and Secession: A Moral Analysis of the Georgian-Abkhaz Conflict in Contextualizing SeCession: Normative Studies in Comparative Perspective, Bruno Coppieters and Richard Sikwa eds., Oxford University Press 2003.

28 Irakli Kakabadze, Russian Troops in Abkhazia: Peacekeeping or Keeping Both Pieces?, Perspectives on Central Asia Vol. II No 6, The Eisenhower Institute 1997.

29 Up in Flames: Humanitarian Law Violations and Civilian Victims in the Conflict over South Ossetia, Human Rights Watch Report, January 23, 2009, available at http://www.hrw.org/en/reports/2009/01/22/flames-0.

30 Statement by President of Russia Dimitry Medvedev, August 26, 2008, available at http://www.kremlin.ru, retrieved on February 27, 2008.

31 International Herald Tribune, September 4, 2008, available at http:/www.iht.com/articles/2008/09/04/america/georgia.php, retrieved on February 27, 2009.

32 Hersh Lauterpacht supra note 11 at 420.

33 Declaration by the Presidency of the Council of the European Union after the Russian Authorities' Recognition of the Independence of Abkhazia and South Ossetia, August 26, 2008, available at http://www.delgeo.ec.europa.eu/en/press2008/26aug2008.html, retrieved on March 1, 2009.

34 Statement by the North Atlantic Council on the Russian recognition of South Ossetia and Abkhazia regions of Georgia, Press Release (2008) 108, August 27, 2008, available at http://www.nato.int/docu/pr/2008/p08-108e.html, retrieved on March 1, 2009.

35 Ministry of Foreign Affairs of Finland, Press Release 302/2008, August 26, 2008, available at http://formin.finland.fi/public/default.aspx?contentid=1 35447\&nodeid=15146\& contentlan=2\&culture=en-US.

36 Parliamentary Assembly of the Council of Europe, Resolution 1633 (2008), available at http://assembly.coe.int/Main.asp?link=/Documents/ AdoptedText/ta08/ERES1633.htm, Resolution 1647 (2009), available at http://assembly.coe.int/Mainf.asp?link=/Documents/AdoptedText/ta09/ ERES1647.htm. 


\section{A Solution for Africa \\ The Coexistence of Regionalism}

Anna Collins Cornell University, 2012

Arts and Sciences: Government Major

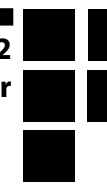

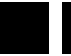

(1)

Regionalism - the efforts of a group of nations to enhance their economic, political, social, and cultural interaction - can assume various forms, including regional integration/cooperation, market integration, development integration, with the intent of accommodating the changing national, international, and regional environment. Despite the fact that to this day, attempts at integration (in particular, market integration based on the EU model) and regionalist impulses as they currently occur have been entirely unproductive throughout the African continent, regionalism continues to be regarded by African leaders as a reasonable strategy for increasing intra-regional trade and for reversing Africa's rising marginalization in the world economy. They continue to be assured by the success of the North American Free Trade Agreement (NAFTA) and the viability of the European Union's (EU) model for integration, which begins with a free trade area or preferential trade area and ends with complete economic integration. The EU model features a specific mode of decision making (qualified majority voting), conflict resolution mechanism (role of the European Court of Justice), budgetary arrangements (revenue collection and distribution), and citizen involvement (direct elections to the European Parliament) and takes on increasingly state-like functions. While extremely successful in integrating its constituent member states in Europe, as a model it is limited, given the unique circumstances under which it was established and promoted. As noted by Emil Kirchner:

Consideration of the $E U$ as a model for other regional integration settings might be limited, given the unique circumstances in which it was established and promoted. Born out of conflict, the EU benefited from special circumstances in its development, e.g. the Cold War, the United States guarantee and nurturing role, and the industrialised nature of the European economies, which are not found elsewhere.

(4)

Because of the achievements of NAFTA and the mass movement toward EU monetary integration, the Abuja Treaty was signed in 1991 by the member states of the Organization of African Unity (OAU) thereby creating the African Economic Community (AEC), a regionalist initiative that lays the groundwork for mutual economic development among the African states, the creation of free trade zones, and the establishment of economic and monetary union by the year 2025 . Given past examples of the ineffectiveness of presentday practices of regionalism in Africa, it is not shocking that the AEC was formed after the failure of the 1980 Lagos Plan of Action for the Economic Development of Africa, a plan drafted by the OAU that was to be the basis for African self-sufficiency and the creation of an African economic community by the year 2000. With respect to Africa and in light of the futile pursuits of regional integration policies there, I argue that if regionalism in the region is ever to succeed to and to lead to integration with the world economy, a new model of regionalism must be formed. Instead of attempting to integrate their economies on the regional level using the EU model, African leaders should endeavor to modify their concept of regionalism and then to integrate their economies into the world economy, a process that will facilitate the growth and development necessary to prevent Africa's further marginalization by the superpowers because, in the words of tralac 
Associate Professor Colin McCarthy, "even if regional integration could in the end succeed as a formal exercise, sustainable growth will require competitiveness in world markets". This is not to say that practices of regionalism should be abandoned altogether but should be made to coexist with globalization after the theory behind them is amended. For one, regionalism (as it has been recently applied) alone cannot defend Africa from the evermore prevalent global economy, which is to suggest that "Africa will only begin to grow again if it opens itself up to the financial and trade flows of the world economy" (Herbst); two, it would be "best for sub-Saharan Africa to integrate with the EC [European Community or European Union] and reap all the possible benefits" since "the temptation to use regionalism as a vehicle for importsubstituting industrialization will only divert attention from efforts to integrate sub-Saharan Africa with the world economy" (de Melo and Panagyria 20); and third, "there are areas, including Africa, where there are proposals [for regional integration], but where the political and social conditions seem no easier to meet than those for global integration. In these, it is difficult to see any argument (except perhaps that of limited bargaining ability) for regions as an alternative or supplement to global integration" (5). However, if revised

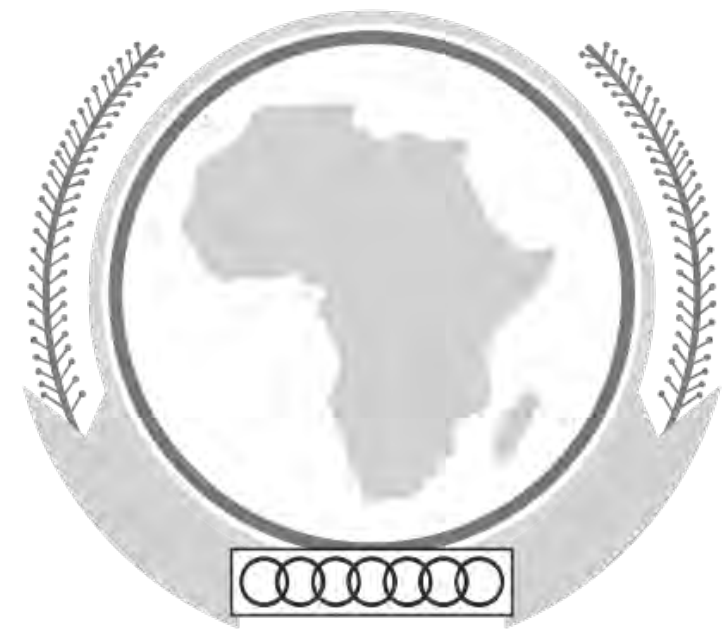

The African Union, established 2002, is the successor organization to the Organizattion of African Unity. to suit African realities and combined with an embrace of the world economy, regional formations on the continent could finally produce the constructive outcomes they were intended to.

\section{The Enduring Effects of the Colonial Experience: Neocolonialism and Globalization}

Once interconnected through the experience of colonialism, the various African nations have more recently been interconnected by neocolonialism (defined as contemporary economic imperialism) and now through the stateless forces of globalization, all of which have restricted their development into individual and selfsustaining entities. Despite the insistence of imperialist historiographies that $19^{\text {th }}$ century European colonialism should be extolled as "a source of light for 'Darkest Africa"' (Duignan and Gann 3), the encounter between Africa and Europe was essentially antagonistic. The ethnocentric bias and narrow self-interests that dictated the actions of colonial rulers of the time continue to have a negative impact, first in the form of neocolonialism and then in that of globalization. Indeed, the close economic ties between former colonies and former colonial powers favor the argument that the latter established mechanisms by which to continue their control over newly emergent African countries, even after their independence- the very definition of neocolonialism. For instance, though it gained independence from Britain (its one time colonial administrator) in 1960, one of Nigeria's major partners in external trade today is the United Kingdom (Ekpoh and Umo). Even in 1989, the Federal Military Government of Nigeria was citing "the enhancement of Nigeria's relations with member countries of the European economic community (EEC)" (Matthews 168) as one of the priority issues of the country's foreign policy. As we can see, "the roots of Nigeria's post-independence politics are deeply entrenched in its colonial history" (Osaghae 1) and it is therefore highly likely 
that many of the country's modern economic malformations "are a direct consequence of the state-building and economic integration processes begun under colonial rule" (1).

Now the era of neocolonialism is giving way to a more subtle method of colonialist management: globalization, a process of transformation that has activated for Africa the veritable "race to the bottom" and has created for the continent an environment in which multinational corporations, in alliance with some of Africa's most corrupt leaders, exploit the land for its natural resources, leaving the population to underdevelopment, poverty, and destitution. Once regionalist theories are reevaluated, however, such downsides may effectively be eliminated. While I understand that the interests of some of the world's most powerful industrial nations as well as the legacy of the region may stand in the way of such a reevaluation, this is separate problem and one l encourage other scholars to address. Rather, this paper proposes a solution to the region's misguided appreciation for the EU model of economic integration, assuming in its course that such a solution is indeed possible.

Of the three interconnecting experiences I have mentioned and briefly described- colonialism, neocolonialism, and globalization- our focus will be the last of these-specifically, the regional integration processes that are attractive to Africans as a result of globalization's widespread prevalence. It is the purpose of this paper to argue that by resorting to regional integration alone in the face of globalization, turning a blind eye to its pervasiveness, Africa is conducting its own demise, expediting the dismantlement of their own failing postcolonial developmental states. While it may seem logical of Africa to respond to the devastating effects of globalization by fostering economic unity using a model that has been previously met with obvious success, it would be more intelligent to abandon this ideal and take into account the region's unique realities so that it too may one day profit by globalization, a force that will undoubtedly continue to grow in strength. After all, because of the elite and hegemonic United States' ability to "set the [global] agenda, define [crises], and mobilize support for policies among both countries and nongovernmental forces" (Zakaria 247), the ideology of neoliberal economic integration will only become increasingly more dominant on the world stage.

\section{The Dangers of a Strict Pursuit of Regionalism}

Critics of my argument would contend that because the forces of globalization have visibly enhanced the prosperity and prominence of many nations (such as the United States, China, and India), they are now widely and erroneously viewed as a fail-safe route to increased peace and wealth. They would also assert that I in my position have failed to remember that the transformative changes associated with globalization are typically reserved for the already advanced democracies (with the exception of China, a nation characterized by a rare combination of illiberal domestic policy and capitalistic economic systems), and that desperately poor and institutionally weak nations such as Africa are unable to confidently meet the national security threats (such as terrorist organizations) to which globalization contributes as they lack the attributes of the US (such as its size, power, and wealth) that allow it to moderate the effects of globalization/provide insulation for itself against disruptive forces. While the United States, my critics would continue, with its democratic domestic political processes, can maintain autonomy by eschewing the global market or, by embracing the market, gain new capacities, Africa- characterized by low living standards, absence of foreign and domestic investment, shortages, privation, foreign exchange scarcities, moderate capacities for governance, etc.- falls prey to a diffusion of control that reinforces institutional malformation (Avant 106) and that encourages attempts at EU-inspired regionalization. 
Today, they persist, the consensus on the imperative of global economic integration has led to a perversion of priorities such that the implementation of standardized integration strategies has become a substitute for the design of country-specific development alternatives. In the words of economist Dani Rodrik:

Advocates of global economic integration hold out utopian visions of the prosperity that developing countries will reap if they open their borders to commerce and capital. This hollow promise diverts poor nations' attention and resources from the key domestic innovations needed to spur economic growth.

To summarize the case of my opponents: widespread confidence in global integration policies among the elite, advanced nations of the world encourages poor nations such as Africa to divert administrative capabilities, human resources, and political capital away from development priorities and to devote these assets to attempts at integration that will ultimately undermine their nascent democratic institutions.

These critics are the same who argue in favor of strict regional integration processes, simultaneously ignoring the inevitably of globalization and forgetting that while EU-based schemes for successful regional integration have been worthwhile in the more advanced Western nations, they have yet to evolveinthedevelopingAfricannations. Forone, background conditions favorable to EU-based regional integration do not exist, a concern of the neofunctional theorists who observe the limited capacities and malformation of Africa's institutions. However, if Africa were forced to face the challenges of increasingly invasive globalization, it will simultaneously be forced to undergo extensive and ultimately beneficial institutional reform. Secondly, and in the same vein, the corruption and limited authority of African leaders (in other words, their merely moderate capacities for governance) produces weak institutional structures that render regional integration-which would serve only to group these feeble institutions and abusive leaders together- a nonsensical choice. Again, if compelled to integrate with the world economy, Africa would be obliged to undergo positive reforms so as to be more compatible with western ideals of political and social liberalism. Thirdly, integrative movements in Africa result in observably unequal economic distribution between the African nations because of a lack of clarity in the formulation of distributional strategies. While it is true that global (as opposed to regional) integration may also result in an unequal distribution of gains between rich and poor countries (as well as obvious disparities in affluence and serious asymmetries in social, economic, and political opportunities), it is more probable that said gains (economic or otherwise) will be balanced out with the US acting as principal moderator over questions of apportionment. The words of game theorist John Nash are of note in "The Bargaining Problem", at the center of which he argued that the question is not whether a particular arrangement is better for everyone than no cooperation whatsoever, but whether there is a fair division of benefits (that is, a fair distributional arrangement results from cooperation). Due to its dynamic, open, multicultural society, incomparably sized military, high standards of education, and newfound position to restore its worldwide legitimacy under President Obama, it is likely that the US, despite a relative diminishment in power, will remain a hegemon, creating conditions under which the "fair division of benefits" and higher levels of sustainable wealth in Africa are more likely to occur.

Fourthly, African nationalism, which arose in response to the colonial state and traditional dynastic identities as a mode of resistance, poses a challenge to regionalism. Though written twenty-three years ago, it is still true today that the "net effect" of regionalism has been "the creation of regional entities whose institutions exhibit limited or non-supranational characteristics which allow the leaders of member-states to protect 
the interests of their national entrepreneurs while discriminating against non-nationals. Competition and antagonism often result in the breakdown of integrative systems" (Okolo 122). Such regionalist behavior is combated by Africans who would prefer nationalism to be the official state ideology and whose focus is the African nation in its entirety. By engaging in global economic integration, the various African nations could be addressed on an individual level based on what they personally have to offer to exchange whereas by engaging solely in regional integration, the nations are thrust into a single and barrier-less collection. And fifthly, not only do the doctrines of regionalism and nationalism compete, there is also ideological competition between regional partners whose orientations differ on issues such as foreign private enterprise, policies toward opposition parties, the allocation of industries on a regional basis, the set up of foreign trade, the role of the state, domestic socioeconomic policies, etc.

\section{The Dangers of a Strict Pursuit of Globalization}

Having now examined the basic flaws in the strict pursuit of regionalist policies, we will now examine those of the strict pursuit of globalization/neoliberal policies with the intent of gradually illustrating why such policies are most effective if combined. Neoliberalism- the redefinition of classical liberalism as an orthodoxy of limited government intervention, privatization, the demise of the welfare state, and the so-called Washington Consensus- has been at the center of African economic policy in the form of IMF/ World Bank Structural Adjustment Programs (SAPs), which have failed to reduce the African countries' marginalization within the world economy. While the demand for the removal of trade barriers and for more outwardlyoriented trade policies has done more to open the economies of Africa than has any regional economic organization, such liberalization has not produced increased intra-regional trade among the African countries, but instead with the core states of the capitalist world economy. This trade, furthermore, is primarily one-way with the core capitalist countries flooding the African periphery with more efficiently produced and/or cheaper products that render the African industrial sector unable to compete and thus lead to massive de-industrialization. Globalism is, according to Robert Keohane and Joseph Nye "a state of the world involving networks of interdependence at multicontinental distances. The linkages occur through flows and influences of capital and goods, information and ideas, and people and forces, as well as environmentally and biologically relevant substances (such as acid rain or pathogens). Globalization and deglobalization refer to the increase or decline of globalism". For Africa in general and for regionalism in particular, the ramifications of globalization have been significant. Because of it, Africa has been further marginalized in the world economy and the sub-Saharan African countries "remain constrained by weak supply and demand capabilities, while lacking institutional capacities. They are, therefore, also less able than other countries to reap potential trade/ investment/ technological transformation benefits from globalisation, whereas for other communities it has contributed to increased impoverishment, inequalities, work insecurity, weakening of institutions and social support systems, and erosion of established identities and values. Thus, for a considerable amount of people, this leads to less human security, more vulnerability and increased social conflict" (Boas, Marchand, and Shaw). In spite of the fact that sub-Saharan African nations are already partially integrated with the world economy because of their export activity, these exports are subjected to the characteristic price fluctuations of the global market (particularly now that the global financial market turmoil has slowed global growth and demand for Africa's exports), while Africans continue to refuse to diversify their exports towards more dynamic primary 
commodities and manufacturing goods, both of which are less prone to the vagaries of international markets and attract more significant foreign investment. By seizing upon globalization opportunities alone, Africans compromise their own workers, industries, and regional partners.

Take, for instance, the case of the EU-South Africa FTA (Free Trade Agreement) (implemented in 2000 and still in effect today), an agreement on trade, development, and cooperation between the European Community and its member states and the Republic of South Africa, signed by South Africa with full knowledge that it would have disastrous consequences for both the Southern African Customs Union (SACU) and the Southern African Development Community (SADC). Although a SACU treaty stipulates that all such treaties and agreements must be approved by all members, none of Botswana, Lesotho, Namibia, or Swaziland were consulted. As to the SADC community (comprised of some 15 African countries as of July 2005), it was intimidated by the possibility of lower-priced and more efficient EU goods penetrating its markets and undermining its agricultural sector as well as frustrated by South Africa's cooperation with the EU itself, negotiations with which lead South Africa to feel so comfortable with integration into the world economy that it became unmindful of (or perhapssimplyaccepting of)theconsequences that such an action could have for its own South African economy. Furthermore, the US, naturally apprehensive about the progress the EU has made in penetrating South African markets, has entered into discussions with South Africa about proposals for a US-SA FTA, the inception of which would only exacerbate the consequences of capitalist ventures into South African markets and feed into the ideology of South African exceptionalsim, an idea reflecting South Africa's belief that it differs qualitatively from all other African nations when it has actually not "managed to 'escape the [colonialism-imposed] fate suffered by the continent"' (Lazarus). Not only would the adoption of this ideology inflate South Africa's sense of worth in matters of economic decision-making, it would also alienate the other members of the SADC. About the negative consequences of $\mathrm{EU}$ and US-SA FTAs, Willem Bosman, Director of Regional Economic Organizations within the South African Ministry of Foreign Affairs, pronounced that SACU members would have to be told that "you are on your own. South Africa cannot any longer provide for you 50\% of your budget... Now you have to tax your own people; you have to work according to the structures of a free independent country"a statement that suggests South Africa's loss of economic hegemony because of a new dependence on the capitalist core and expired need for the other SACU countries (bound to suffer) as a market for their agricultural and non-international competitive manufactured products. Should open trade regimes and integration into the world economy (in essence, globalization and neoliberalism) fail to satisfy South Africa's unique economic needs, the SACU countries will have so far deteriorated economically that they will no longer be able to purchase South Africa's products- a risk to which South Africa pays frighteningly little attention.

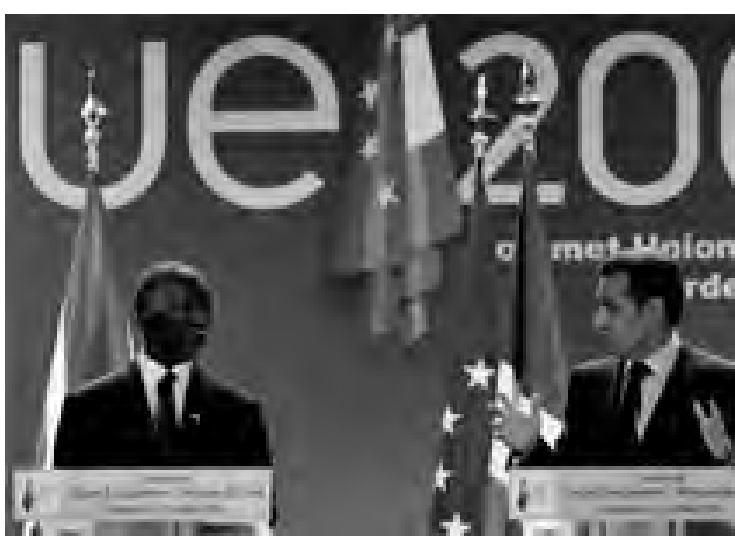

Former South African President Thabo Mbeki and President of the Council of the European Union Nicolas Sarkozy meet at the Inaugural EU-South Africa Summit in July 2008. 


\section{The Drawbacks of the External Guarantor Model}

Given the risks associated with the narrow pursuit of EU-style regionalism (when globalization is ignored) as well as the narrow pursuit of globalization (when regionalism is ignored), Africa can only harness the benefits of both policies by allowing them to coexist. One possible method of achieving this state of coexistence would be to make the EU external guarantor to regional integration in Africa. External guarantee refers to when a domestic institutionbearstheresponsibilityofrepayment to either institutions abroad from which Africa chooses to borrow money or to foreign-funded financial institutions established within Africa. As external guarantor, the EU would act as the financial institution authorizing this business and encourage a partnership between the developed European and developing African nations. The model for external guarantee has its basis in the West African Economic and Monetary Union (UEMOA), a regional organization established in 1993 by eight West African countries in conjunction with France. By early 2000, members of the UEMOA had adoptedacustomsunionand commonexternal tariff and have since developed a common program of action on trade liberalization and macroeconomic policy convergence. As noted by Jeffrey Fine and Stephen Yeo, who proposed this new paradigm for regional integration in 1997, "France could have commenced withdrawal...from an arrangement that had proven increasingly costly to maintain in recent years. Instead, it has moved in the opposite direction, embedding an expanded role in a new international treaty for which it acts as the ultimate guarantor. Furthermore, the commitment is open-ended, involving the establishment of new multilateral institutions and surveillance of macroeconomic policies whose credibility ultimately rests on France herself. In short, France's role as guarantor appears significantly greater than under the previous monetary agreement" (451).
Acknowledging that the justification for closer regional integration is the pursuit of sustained economic growth, Fine and Yeo note that "we depart from traditional approaches to regional integration by suggesting that its virtues lie not in its ability to stimulate new trade, but rather in its ability to provide a framework for locking in sound and stable macroeconomic policies that will in turn induce faster accumulation, and more effective utilization of physical and human capital" (449). This "framework for sound and stable macroeconomic policies" they suggest be arranged and monitored by the external guarantor. Furthermore, with the EU as external guarantor, any structural adjustments, ratherthan being implementedall at once, could be implemented incrementally, allowing Africa to strengthen gradually and with a greater sense of self-reliance.

Nonetheless, there remains uneasiness over Africa's dependence on external agents or donors, seen as inimical to long term development in Africa; although the external guarantor model may indeed instigate good governance practices, it would almost certainly entail intrusive conditionalities that would worsen Africa's already severe development challenges as the continent became increasingly dependent on extra-regional powers to fund the regional agenda as well as to provide development capital, giving said powers the ability to determine regional policy. While attempts to reconstruct Africa from the outside may enhance the accountability of African governments to the rest of the world, there is no evidence to suggest that such a structure creates long-term economic fortunes, a viable and independent African entrepreneurial class, or political stability. The last thing Africa needs is a perfunctory effort from outside Western states that are unwilling to give sustained and genuine support to initiatives in which there own national and security interests are only marginally involved, especially when the project may very well be perceived as neocolonialism. 


\section{Alternative Approach: Deserting the EU Model and Drawing on Regional Realities}

The perceived failure of the external guarantor model leads us to a second possible method of achieving regionalism's and globalization's coexistence beginning with abandonment of the EU model, proponents of which claim only seems to be committed to the principle of differential treatment for developing, vulnerable countries. Following abandonment, the continent's regional organizations, in order to "play a real role in the economies of the South", must be "embedded into the real life context of these economies" (Boas, Marchand and Shaw). That is to say that the regional organizations must be reformed, must become fixed in reality, must act as a source of connection between the formal and informal economies of Africa, the latter of which has been either consistently discounted by some countries or depended on too heavily by others. As to the situation in which the informal economy is consistently discounted, Boas et al remind us that:

Quite often it is [in the informal economy], and not in the formal economy, that we find considerable...imagination, innovation, and entrepreneurship. The informal second economy covers a whole range of activities, from street vendors and small-scale informal cross-border trade to the warlordism of Sierra Leone and Somalia....

Rather than racing immediately for the aid of external guarantors while ignoring the regional agenda, Africa should instead begin with its preexistent formal and informal trade flows and cooperation networks between neighboring countries, the multitude of which would constitute an excellent starting point for formal regional organization/would effectively inform the design of regionalization schemes and institutions. Once the informal and formal sectors of the economy have been reattached so that countries overemphasizing informal trade stop losing money because of their bias and countries underutilizing informal trade begin to take advantage of it (for instance by enhancing food security with the development of an informal agricultural sector, which provides markets for surplus farm produce and income for the local producers, opportunities for those producers to invest capital in nonagricultural activities, and finally food in low income houses in the major towns), Africa will be strong enough to pursue policies of globalization as it will have independently put in place the prerequisites for such policies. If the EU (or other external financial institution) is to have any role, it should be to implement regional projects that will stimulate economic growth within to develop and or improve existing regional infrastructure. Essentially, the approach to regionalism should be predominantly introverted and should involve the mobilization of domestic resources so that collective self-reliance receives the most emphasis. Whereas excessive dependence on the international system will continue to do Africa more harm than good, this alternative approach will offer better policy frameworks for long term development and integration. Restructuring the existing continental and regional groupings to give priority to the increasing volume of underutilized intraregional trade will involve consolidation of institutions such as regional Organizations for Economic Cooperation, African Payments Unions, regional clearing houses, and compensatory mechanisms (Mbaye).

\section{Conclusion}

In the end, in order for the coexistence of regionalism and globalization to work, the intergovernmental, supranational EU model can no longer be viewed by Africa as the only workable solution to marginalization; regional cooperation must also be pursued as one of a two-part economic strategy. Once the current infrastructure of Africa is improved and reinforced, the continent will gain both economic autonomy and the ability to act as an active participant in the international economy, at which time their marginalization 
by the capitalist core will decrease. Of course, the theory of regional integration in Africa must be redefined if this vision is to be realized, and regional market integration must be rethought (in other words, must disconnect from the EU model and recognize the African realities). Should this be accomplished, Africa will eventually profit by the advantages of both regionalism and globalization.

\section{End Notes}

Avant, Deborah. "The Marketization of Security: Adventurous Defense, Institutional Malformation, and Conflict." Globalization and National Security. CRC P, 2006. 105-41.

De Melo, Jaime, and Arvind Panagariya. The New Regionalism in Trade Policy: An Interpretive Summary of a Conference. Chicago: World Bank Publications, 1992.

Duignan, Peter, and L. H. Gann, eds. Colonialism in Africa 1870-1960. Vol. 5. Cambridge UP, 1988.

Ekpo, A. H., and O. J. Umoh. "Growth and Direction of External Trade." Online Nigeria. 17 Dec. 2008. 17 Dec. 2008 <http://www.onlinenigeria.com/ economics/?blurb=496>.

"France (Republic of)." Official Web Site of the Department of Foreign Affairs: Republic of South Africa. 7 May 2007. 18 Dec. 2008 $<$ http://www.dfa.gov.za/foreign/bilateral/france.html>.

Herbst, Jeffrey. "Developing Nations, Regional Integration and Globalism." Handley and Mills: 33. "Interview with Willem Bosman, Director of Regional Economic Organizations." Interview with Margeret Lee. 2 June 1998.

Keohane, Robert O., and Joseph S Nye. “Globalization: What's New? What's Not? (And So What?)." Foreign Policy 2000: 105.

Kirchner, Emil J. "The European Union as a Model for Regional Integration: The Muslim Word and Beyond." Jean Monnet/Robert Schuman Paper Series 6 (2006).

Lazarus, Neil. "The South African Ideology: The Myth of Exceptionalism, the Idea of Renaissance." South African Quarterly 103 (2004): 607-28.

Marchand, Marianne H., Morten Boas, and Timothy Shaw. “The Political Economy of New Regionalisms."Third World Quarterly 20 (1999): $897-910$.

Mathews, Martin P. Nigeria : Current Issues and Historical Background. New York: Nova Science, Incorporated, 2002.

McCarthy, Colin. "Regional Integration: Part of the Solution or Part of the Problem?" Africa Now (1996).

Nash, John. "The Bargaining Problem." Econometrica 18 (1950): 155-62.

Okolo, Julius E. "Integrative and Cooperative Regionalism: The Economic Community of West African States." International Organization 39 (1985): 121-53.

Okomo-Okello, Francis. "Poor leadership slowing Africa's development." Business Daily Africa. 7 May 2008. 31 Dec. 2008 <http://www.bdafrica.com/ index.php?option=com_content\&task=view\&id=7437\&ltemid=5821>.

Osaghae, Eghosa E. Crippled Giant: Nigeria Since Independence. Bloomington, Indiana: Indiana UP, 1998.

Page, Sheila. Regionalism Among Developing Countries. New York: Palgrave Macmillan, 2000.

Rodrik, Dani. "Trading in Illusions." Foreign Policy Mar. 2001: 55-62.

Mbaye, Sanou. "Should Africa Follow EU Model?" Bangkok Post 24 Sept. 2003. Global Policy Forum. 15 Mar. 2009 <http://www.globalpolicy.org/ globaliz/econ/2003/0924africaeumodel.htm>.

Sen, Amartya. “How to Judge Globalism.”The American Prospect 1 Jan. 2002: A2(5).

Trofimov, Yaroslav. "'Confidence Zone': In Ivory Coast, French Muscle Plays a Peaceful Role."Wall Street Journal 8 Oct. $2003:$ A1.

Yeo, Stephen ., and Jeffrey Fine. "Regional Integration in Sub-Saharan Africa: A Dead End or a Fresh Start?" Trade Liberalisation and Trade Integration Vol. 1: Framework, Issues, and Methodological Perspectives. London: Macmillan, 1997.

Zakaria, Fareed. The Post-American World. Boston: W. W. Norton \& Company, Incorporated, 2008.

Photo courtesy of Mangwanan. "Logo of the African Union." 9 March 2008. Wikipedia. 2 April 2008. <http://en.wikipedia.org/wiki/File:Logo_of_the_ African_Union.svg $>$.

Photo courtesy of The Elysée. "Thabo Mbeki and Nicolas Sarkozy." 25 July 2008. French Embassy in South Africa. 2 April. < http://www.ambafrance-rsa. org/Inaugural-EU-South-Africa-Summit.html>. 


\section{Human Rights in Indonesia: \\ The Consequences of Discrepancies in Domestic versus International Law}
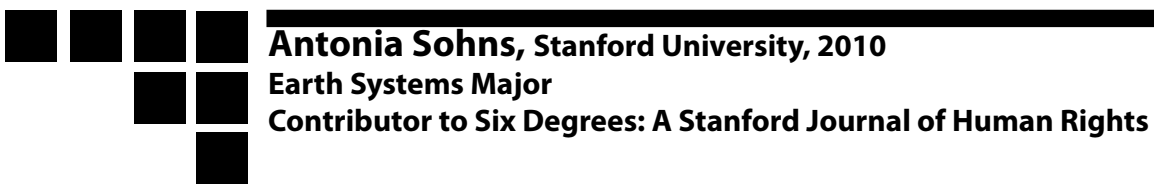

Two years ago, my mom handed me the article, "Below a Mountain of Wealth, a River of Waste," from The New York Times, describing Freeport-McMoRan's mining activities in Papua New Guinea. After reading "Below,"I knew that the world had to change; the injustices that Papuans were experiencing could not continue for long without retribution.

"[A]n American transnational mining company called Freeport-McMoRan...operat[es] the largest gold mine on Earth, not in Africa but in the heart of West Papua" (Leith xv). FreeportMcMoRan Copper and Gold Inc. is the best known subsidiary of PT Freeport Indonesia, operating in West Papua, New Guinea. Freeport's operation there has resulted in the complete remodeling of the society and economy. West Papua is a province of Indonesia; it, along with Papua New Guinea, comprises the island of New Guinea. West Papua has a population of approximately 800,000 people, making it one of the smallest Indonesian provinces. Due to its small size and remoteness, Freeport was able radically to change the social structure there; often these changes occurred without Papuan consent.

Freeport stated that where natural resources are present in a country, it is inevitable that companies will enter the country to mine the resources, if the local population does not choose to do so first, thereby initiating a process of environment change in the country. The devastating transformation of the land in Papua has provoked retaliation from the local Papuans in recent years. In 2006, Human Rights Watch reported that

[a]nti-Freeport demonstrators attacked the hotel [where the Freeport representatives were staying] after being unable to address local officials meeting with Freeport representatives...[d]emonstrations against Freeport have increased in recent months after Freeport security forces tried to evict local miners, alleging their activity was illegal. Protesters accuse Freeport of not providing enough to the people of Papua in return for the mine, polluting the environment, and for being responsible for human rights abuses through their use of the military for security services. (Human Rights Watch)

HumanRightsWatchisnottheonlyorganization to document increased protestation from Papuans.

Although Freeport's presence in West
Papua is not recent, the protests continue. In April 2007, the Xinhua News Agency, the official press agency of the People's Republic of China, reported "police claimed the number of the protesters had risen from 1,000 on Wednesday to 7,000 on Friday" (Xinhua). The protests' escalating size drew international attention. Despite the resistance in West Papua, Freeport will remain in West Papua until its contract expires. Even after Freeport's contract with the government terminates, Freeport and other companies will continue exploring for resources in West Papua. A topographical reminder of Freeport's activities in Papua will also endure in the form of a 1,500-foot deep crater, where a 13,500-foot mountain once stood.

Freeport's success is largely a result of timing and convenience. Freeport and the Indonesian government both benefit from their relationship, which has been accused of being fraught with corruption, bribery, and exploitation. Although Freeport has made efforts to improve its reputation, in order to regain the support of its investors, its questionable actions are not isolated. 
Freeport, along with many other transnational companies, is escaping legal prosecution due to the differences between domestic and foreign laws regulating mining practices, human rights and environmental standards. The discrepancies between these legal systems of the country in which a corporation is established and the countries in which the corporation operates need to be identified and addressed in order to ensure the protection of the rights of indigenous populations and of the environment.

\section{Background}

Broadly, there are three constituencies in the argument concerning the legality of Freeport's actions in West Papua. The first constituency is comprised of mining and engineering companies and businesses that perceive Freeport's procedures as necessary for a successful operation, and believe that Freeport has been very responsible in its actions towards the environment and the

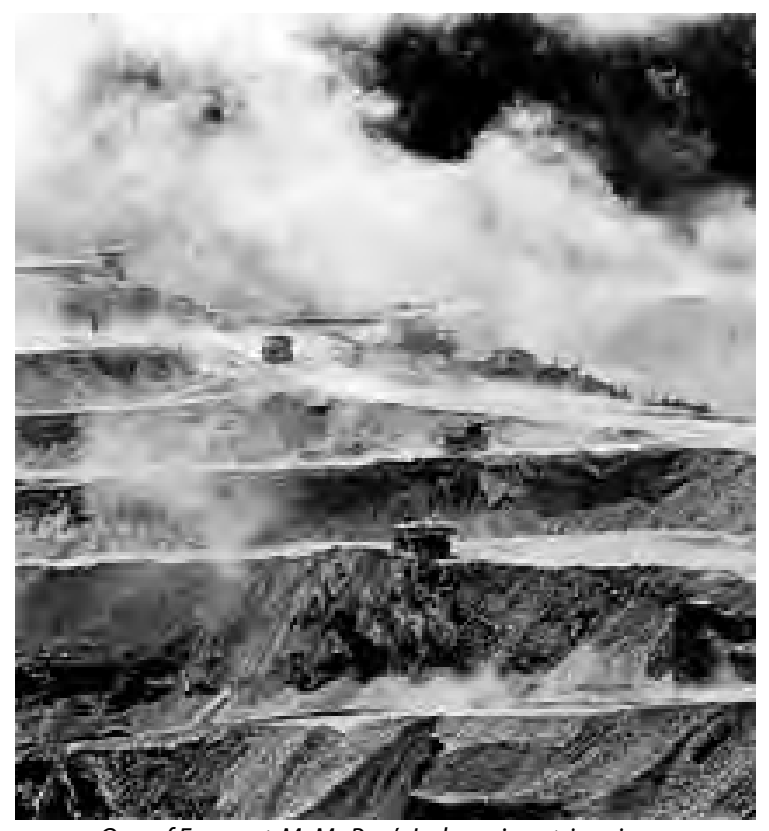

One of Freeport-McMoRan's Indonesian strip mines

Papuans. One engineering and mining journal published, "Freeport's Commitment to Remediation," which discusses Freeport's plans to make its mining site livable after its contract expires. The article even claims that the "site remediation plans... will leave the area in better and more useful condition than it was prior to mining operations" (1). Business Week, states, "Freeport is definitely considered a bellwether for foreign investment prospects." This reveals the business perspective on Freeport's actions. The business community sees the company's operation as an exciting endeavor, even while recognizing that Freeport has violated human rights, given that Freeport has admitted that its "human rights policy is being only partially implemented." While Freeport is supposedly "beginning to do the right thing... it's only a first step... [and] it's way to early to say Freeport has turned over a new leaf" (Business Week).

The second constituency in the argument is Freeport itself. Freeport has published explanations of its actions. Often these publications are in rebuttal to accusations that the company deems unfair and false. James R. Moffett, Freeport's chairman and CEO, who would only "provide written answers to [Business Week's] questions[, wrote] 'it's our responsibility to ensure that the local people benefit from our presence...[and it is] our aspiration to develop relationships based on honesty, equality, and justice"' (Business Week). Moffett's statement presents Freeport as seeking to treat the Papuans fairly and obey all of the legislation to which it is subject.

Thethird constituencyin theargument, consists of human rights activists, journalists, and environmentalists who strongly oppose Freeport's actions in West Papua. This constituency claims that Freeport is corrupt and illegal and has escaped international justice and should be stopped.

Despite adamant opposition to Freeport's behavior in Papua, there has been no proposed solution to solve the discrepancies between domestic and foreign legislation. I hope to propose a solution to this international legal problem, in order to punish the perpetrators of human rights violations, environmental degradation and 
other injustices and to limit or prevent such violations and damage from occurring in the future.

\section{Discovery}

I knew in a blink of an eye what this was about. It was hard to miss, with all the green and blue spots. The copper was obvious. I realized that no one could do anything with it. There were no roads, no harbors, no factories. It was just like a mountain of gold on the moon. (Mealey 71)

In 1936, Jean-Jacques Dozy, a Dutch geologist, found copper ore in the rain forest of Indonesia, naming the site Ertsberg. The copper ore, known as an "ore body," however, was not immediately mined, due to the outbreak of "World War II, the German occupation of Holland [which exercised colonial authority over Indonesia], and the Japanese occupation of West Guinea" (Leith I). Following the end of WorldWar II, Freeport-Sulphur, the predecessor of Freeport-McMoRan Copper and Gold of the United States, became aware in 1959 of the ore body in Papua, and sent a team of geologists to explore for and investigate Dozy's dormant discovery.

When Freeport began exploring the area in the "1960's,...its explorers were among the very first outsiders ever encountered by local tribesmen swathed in penis gourds and armed with bows and arrows" (Perlez, Bonner). In 1967, Freeport became the first foreign company to sign a contract with the Indonesian government permitting mining in the area and foreign investment. The contract outlined many provisions and left many important terms open to interpretation. One example of the loose terms in the mining agreement was that Freeport was not required to submit construction plans to the Indonesian government. Instead, Freeport was responsible to keep the Ministry of Mines updated on their work and exploration. The Indonesian government saw economic growth as their highest priority, and agreed to help "cooperate with [Freeport] in matters such as appropriating land and other property required by the project and in the resettlement of inhabitants who may have been displaced by the project" (Mikesell 133). In addition, Freeport was given full control of exploration, construction, and operation of the project, and it was given full management of marketing, and negotiating long-term contracts. The Indonesian government was responsible to be "familiar with [Freeport's] marketing policies and procedures, and, if requested by [Freeport], be able to assist [Freeport] in dealing with such marketing problems as may arise" (Mikesell 134). The language in the contract left the Indonesian government vulnerable to Freeport's needs and requests, and was the foundation of a wavering relationship that formed thereafter, due to power distribution. In 1974, due to the weakness of some of the terms in the 1967 contract, the Indonesian government sought to revise the contract. Freeport agreed to three revisions, all pertaining to taxes on the company. These changes, however, ultimately had little effect on Freeport's operations.

\section{The Discrepancies}

Freeport was fortunate in the timing of its entry into Papua, New Guinea. The Sukarno government had just been overthrown by a military coup, and a new government, the New Order regime, was looking for "international recognition and political support while attracting foreign aid and investment to foster stability, legitimacy, and development" (Leith 2), which is what Freeport was willing to provide in exchange for gold and copper rights. However, Freeport was hesitant to commit to the New Order regime until it reversed certain of the Sukarno policies that were unfavorable to the company. The Foreign Capital Investment Law of 1958 and the Mining Law No. 37/1960 were two of the most important laws that the New Order regime overturned. By repealing the former, the New Order regime revealed its support for foreign investors, by returning confiscated foreign property, which had been seized by Sukarno, to its former 
owners. The repeal of the latter law revealed the government's interest in "displaying its support for the interests of the license holder [in this case Freeport]...whenever there [was] a clash between the landownership and the mining operation" (Republika).

Once Freeport committed to the New Order regime of Indonesia, the company developed a very close relationship with its President, Suharto. Both Suharto and Freeport "shared an overriding desire to turn the copper and gold in the Cartstensz Range into currency as expeditiously as possible" (Leith 3). Such a desire vitiated the government's interest in regulating Freeport's actions. Their desire for gold, however, left Freeport and the Indonesian government vying over profit percentages and in a volatile relationship. In the beginning, Suharto was grateful for Freeport's support and was aware of Freeport's power, because it contributed heavily to the economy. It is the largest taxpayer in the economy; "[f] rom January to December 2006, Freeport Indonesia paid its financial obligations to the government of Indonesia in the sum of 1.6 billion dollars...dividends account for 159 million dollars and royalties for 146 million dollars" (Agence France-Presse). The company is also the largest employer in West Papua.

Freeport's prominence in West Papua and the importance to the government began when it signed the 1967 contract. With time and an increase in the company's copper and gold findings, Suharto and the Indonesian government gained confidence and began demanding more of Freeport. Suharto required a" 10 percent share in the operation... [and] [e]ventually, Freeport financed Suharto's government, his closest associates, and even the president into the company on exceptionally favorable, if not questionable, terms" (Leith 4). Here, the author highlights the evolution of Suharto's and Freeport's relationship and how it became increasingly corrupt over time. Freeport's close ties to Suharto and its financing of the government was convenient for the parties involved. It is this exploitative relationship that was both the cause and continued result of Freeport's activities in West Papua.

\section{The Holes in Between International and Domestic Law}

For more than thirty years the American company, with its rigorous home-state laws against corruption, was able to operate with impunity by adapting to, and indeed thriving in, a business culture anchored in corruption, collusion, and nepotism. (Leith 3)

\section{Domestic Legislation}

Freeport is a New Orleans based mining company that has many mining sites around the world. Its largest subsidiary is in West Papua, New Guinea. Freeport is a transnational company, and therefore needs to follow different laws and regulations. The United States government restricts a transnational company with corruption and foreign investment laws. In terms of a transnational company's relationship with foreign governments, however, the company is free to establish contracts with the foreign governments defining the terms

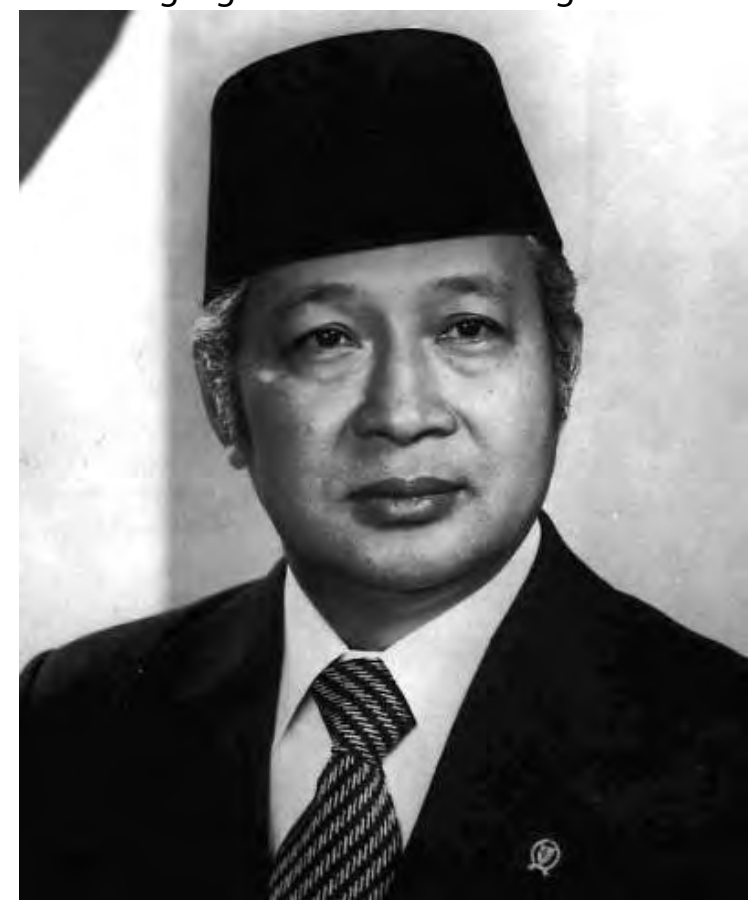

Suharto came to power in a coup, and was the President of Indonesia from 1967 to 1998. 
of its operations, often defining weaker environmental and human rights standards than would be legal in the United States. One law that Freeport was accused of breaching in its sinuous relationship with the Indonesian government was the United States Foreign Corrupt Practices Act (FCPA). The FCPA was enacted in 1977, ten years after Freeport had begun establishing its relationship with the Indonesian government, and the FCPA was revised in 1988. The FCPA prohibited

the bribery of foreign government officials by U.S. persons and prescribe[s] accounting and recordkeeping practices...[making] it illegal for U.S. persons to bribe a foreign government official for the purpose of obtaining or retaining business. The wording of the FCPA is quite interesting and makes its scope rather clear. The fact that the FCPA deals only with bribes made to foreign government officials acts to exclude from the FCPA ambit payments to foreign persons who are not government officials. Additionally, the fact that the FCPA deals only with bribes that are intended for the purpose of obtaining or retaining business acts to exclude grease or facilitating payments from the scope of the FCPA. A grease or facilitating payment is a payment made to expedite or secure the performance of a routine government action. (FindLaw)

As described by the author, the drafting of the FCPA made the legislation inadequate to prevent Freeport from paying the government officials or military officers in bribes, in order to "grease" them into helping to support Freeport's operations in West Papua. This is one example of the ineffective legislation that the United States has to restrict the actions of their companies abroad. Freeport is therefore left to police itself. Considering there is no real international policing system to scrutinize Freeport's operations; Freeport was left with significant leeway potentially to abuse its relationship with the Indonesian government. In addition to Freeport's ties to the Indonesian government, Freeport benefited from the Indonesian legal system, which is almost completely powerless when compared to the
United States' legal system. Its ineffectiveness is derived from the close relationship between Freeport and the Indonesian government, given the latter's reliance on Freeport for a strong economy and desire to remain on good terms with Freeport. This is in contrast to the United States' legal system, which has stricter regulations on mining and the environment within the United States. However, despite the more stringent legislation, companies are still capable of committing grave injustices. Companies are able to escape legal consequences in the United States due to their affiliation with lobbyists and their participation in the election process. The coal-mining lobby, for example, has a large influence on election campaigns and results as donors. Therefore, due to a lobby's presence and power in Washington, D.C., the elected official is often unwilling to repay their supporter by imposing harsh restrictions on the company's actions or the mining industry.

One example of the strong influence that a lobby has on the government was observable in the 2004 presidential election. The coal lobbyists heavily sponsored President Bush's campaign. In return, he changed "the wording in the Clean Water Act so that mining waste became benign "fill." This made it legal for coal companies to dump hazardous waste in the rivers, streams, and waterways around the mine. Coal companies in eastern Kentucky utilize the same methods of mountain top removal as Freeport. Mountaintop removal is a process where the mining company literally removes the top of a mountain in order to access the minerals below. This is a very destructive technique that requires explosives, and the companies often place the land in the surrounding valleys and waterways. This can lead to an increase in mercury levels in the water and potential harm to society, because mercury is toxic to a person's health in high concentrations. Understanding the similar practices that Freeport and coal companies use in the United States and abroad is important because it reveals the lack of regulation across 
the board in mining; however, it also exposes a deeper issue that the weakness revealed in the United States' legislation is actually some of the strongest worldwide. Luckily in the United States there are organizations that help ensure the government and companies are kept in check.

Changes in our legislation that benefit individuals to the detriment of the public interest are unjust. While balancing society's interests in legislation is difficult, because "it's difficult for us to acknowledge the wisdom of policies that clash with strongly held values" (Reece 216), it is essential in order to guarantee justice. In America the desire to satisfy individual interests often overrides our concern for helping others; it is interpreted as "individualism...as one's unfettered right to use resources, [which] clash[es] with the values of conservation and preservation of those resources for future Americans" (Reece 216). Please see if the material between the brackets should be revised for clarity. The American standards for mining companies domestically are unfortunately some of the strongest and most restrictive in the international community. They are not forceful enough to protect the environment and the rights of the people around the mining site; the United States government is designed to prevent ties between companies and the government from forming and becoming contaminated with corruption and greed; but as with all systems of government, though, this is not always successful. However, the United States government is immune from a company's overpowering the entire government, as Freeport was able to in Indonesia. This difference in the United States, along with watchdog groups and concerned citizens, ensures that unjust companies will be held responsible for their actions.

\section{Freeport-McMoRan:}

\section{A Criminal Company?}

The lack of existing domestic legislation and the legal discrepancies between international and domestic law allowed Freeport to define the legality of its own operations. Freeport drafted and signed its contract with the Indonesian government prior to any existing legislation, like the FCPA that regulated its actions abroad. The FCPA made Freeport's relationship with the Indonesian government criminal, because Freeport had been using bribery and coercion to increase their profits. Even after the FCPA was passed in 1977, Freeport continued to escape legal retribution, because the United States government was benefiting from Freeport's actions abroad; "[c]ompany records obtained - show that from 1998 through 2004, Freeport gave military and police generals, colonels, majors and captains, and military units, nearly $\$ 20$ million. Individual commanders received tens of thousands of dollars, in one case up to $\$ 150,000$, according to the documents. They were provided by an individual close to Freeport and confirmed as authentic by current and former employees" (Perlez, Bonner). Although it is illegal under Indonesian law for a government official to accept direct payments from a company, these facts, obtained by The New York Times, reveal that illegal payments were being made. This reveals the corruption that existed between the Suharto regime and Freeport.

In addition to bribery, Freeport was connected to several human rights violations. Freeportís "Guiding Principles for Indonesian OperationsóPeople and the Community" states that it is "one of the few multinational companies in the extractive industries with a well-defined human rights policy and implementation program - [and] [i]n developing this policy [was] guided by the United Nations Universal Declaration of Human Rights and the Voluntary Principles on Security and Human Rights." This statement, however, is refuted by its actions in West Papua. Freeport had

company security forces being accused of shooting the local people and allowing the military to use its facilities to commit 
atrocities against the citizenry in 1995 - [e] ven though Freeport personnel were aware of human rights violations for years, it would appear that as in the past, the company failed to make any effort to prevent such actions, advise the appropriate authorities, or protect the Papuans whose land it exploited. (Leith 218-9)

Not only were Freeportís own security forces accused of violating human rights, but Freeportís operations also required a military presence from the government for security of the mine. Freeport was therefore connected to the violent acts of the military against the indigenous populations; "while [Freeport] cannot be blamed directly for the human rights abuses the military commits, neither [can it be] completely free of culpability there is an undeniable connection" (Leith 219) between the military protecting the company and the human rights violations that occurred in Papua.

Lastly, Freeport has been accused of destroying the Papuans' land and the environment. Freeport states in the same "Guiding Principles" report, in its Mission Statement, that it is committed to the "protection of the environment" and that it would "go beyond its legal and contractual commitments" to the government and Papuans in ensuring that they benefited from the mine and in protecting the environment.

Simon Wandikbo...the village pastor, recalled that in 1969 a special vote was held to decide Papua's future. Simon's aunt was among 1,022 tribal elders selected to take part. The vote was sponsored by the United Nations, with U.S. support. The aunt, now dead, told him the elders were coerced into choosing to remain with Indonesia, he said. Studies by academics in the Netherlands and in Britain, as well as declassified U.S. documents, support her contention. 'They promised that we would belong to a great nation and have great homes and we would be wealthy...[t] hat was in the 1960s. Now it's 2006. Nothing has changed -- except for the worse.' (The Washington Post)

This quote indicates the expectations that the
Papuans had before Freeport became heavily invested in West Papua. The people believed that their lives would be improved by the company's presence, and that they would share in the profits that the company made, when, in fact, they were exploited for their land.

Although Freeport was complying with the regulations established by Suharto under the 1967 contract, the regulations were hardly restricting. By the end of Freeportís contract with the Indonesian government, Freeportís own estimates state that it will generate an estimated six billion tons of waste - more than twice as much earth as was excavated for the Panama Canal. Much of that waste has already been dumped in the mountains surrounding the mine or down a system of rivers that descends steeply onto the islandís low-lying wetlands, close to Lorentz National Park, a pristine rain forest that has been granted special status by the United Nations. A multimillion dollar 2002 study - paid for by Freeport - and not previously made public, noted that the rivers upstream and the wetlands inundated with waste were now "unsuitable for aquatic life" (Perlez, Bonner).

This account reveals the severe and damaging effects that Freeportís actions are having on the environment. It also exposes Freeportís actions as harmful to the villages and population around the mine, because Freeport is moving

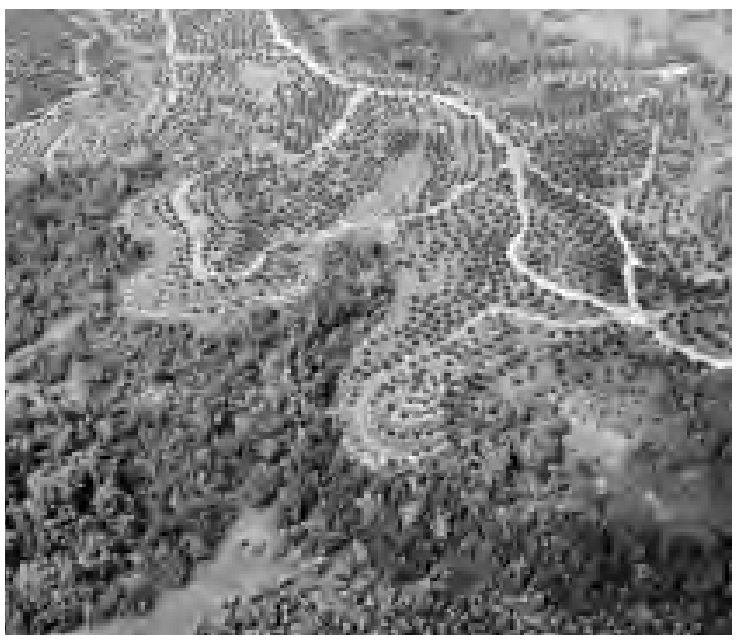

The effects that industry has on Indonesian rainforest deforestation 
land and minerals from the mine, placing it elsewhere, destroying the surrounding ecosystems. The land is a common resource on which many Papuans rely for survival. The lenient regulations in Indonesia do not curb the abuses in which Freeport is engaged "[i] $\mathrm{n}$ the United States, Freeport would not be allowed to discharge sewage and tailings directly into the local river system" (Leith 251). By contrast, in West Papua Freeport is under relaxed supervision, which prevents Freeport from being properly regulated. Because the Suharto government had a financial interest in Freeportís operations, and did not investigate environmental reports from the Papuans, the extent of the damage to the environment from Freeportís operations has not been fully investigated.

Freeport's abuse of legal standardswith the Indonesian government, its degradation of the environment, and connection to human rights violations expose Freeport as a corrupt company. It used the lenient foreign legal environment to its own advantage, while destroying the Papuan community around it. Although its actions were considered "legal" in Papua, they were considered highly immoral by "watchdog groups such as Human Rights Watch and Interfaith Center on Corporate Responsibility" (Johnson D1) and would be illegal in the United States, Freeport's home country.

\section{Not An Isolated Problem}

Unsurprisingly, Freeport is not the only company that takes advantage of existent leniencies in foreign legislation pertaining to their operations, human rights standards, and environmental regulations. Currently, and in the past, companies have exploited the legal system, as Freeport has. ChevronTexaco abused the lack of legislation in Angola. Angola is fraught with corruption due to the prevalence of oil, an increasingly scarce natural resource. The exploitation in Angola was so prevalent that the World Bank called it a "cancer of corruption" (McMillan). Angola mirrors the problems witnessed in West Papua with Freeport. The '"marriage of convenience' between the oil countries and the companies mean[t] that obscuring information [was] not difficult" (Karl, 476). In Angola, the United States government tried to reverse the corrupt practices by attempting to pass the Publish What You Pay Act, which required companies to publish where their payments went, making "it harder for developing country-government's to misappropriate the revenues" (McMillan). An American company operating in Angola, Chevron-Texaco, argued against the act. The board of Chevron-Texaco stated:

publish-what-you-pay... break[s] the terms of contracts... '[w]hether it's the oil industry or any other industry, obviously you wouldn't want your competitors to know what you pay...[w] recognize that we have a responsibility to the people of Angola, but when it comes to government policy we feel very strongly that it's not our role to suggest or influence national economic policy.' (McMillan)

In this statement Chevron-Texaco makes it explicit that it is not going to comply with the new legislation, because they view it as jeopardizing to the success of their business. Chevron-Texaco's corrupt relationship with the Angolan government is representative of the government's relationship with the other oil companies operating in the country.

\section{Conclusion}

\section{Can This Problem Be Resolved?}

Although many countries are plagued with the presence of a natural resource, known as the resource curse, because the resource results in fraud and civil war, there are a few examples where a natural resource has actually benefited the country. Norway has "avoided the worst manifestations of the resource curse" (Karl 484), because before it began exploiting its natural resource it had a means of controlling the influx of wealth.

Good institutions must be in place prior to the exploitation of oil. Good governance, transparency and participation are 
prerequisites for the effective utilization of petrodollars to alleviate poverty and prevent conflict-not the other way around. (Karl 485)

Here Karl highlights the importance of having a stable, democratic government established prior to exploring and utilizing a country's natural resource for the betterment of the country. If a country decides to exploit the resource prior to having these institutions in place, foreign investment and the individuals responsible for administering the government are likely to corrupt the system, by establishing laws and practices that benefit the ruling elite. Norway provides the world with an example of how natural resources can result in high profits that benefit the entire population. It ranked first out of 177 countries in the United Nations Human Development Report 2006. Norway's Human Development Index was.965, which measures "three dimensions of human development:...lifeexpectancy....adultliteracy and enrolment at the primary, secondary, and tertiary level... and by purchasing power, PPP, income" (UNDP). In addition, Norway is using "the money [from the oil revenues] to advance an ambitious ethical code they established in 2004 for their oil reserves, known as the Government Pension Fund" (Landler 1). It is pulling investments from countries whose actions they deem unethical. Already Norway has sold off more than $\$ 400$ million in shares from Wal-Mart. It has blacklisted Boeing and Lockheed Martin, and

Freeport McMoRan, which Norway accuses of severe environmental damage at its copper and gold mine in Indonesia. Freeport responded to the allegations with a 25-page, point-by-point rebuttal. Norway's report, it said, 'is utterly false and bears no resemblance to our company and its operations.'

(Landler 1)

Norway clearly has significant power due to its oil reserves. It is using its dramatic rise in power in order to advance ethical practices within its own legal domain and of other countries by withdrawing or investing support in companies. Norway is redefining how governments choose to invest in companies. Hopefully, Norway's influence on the global economy will have lasting effects and set a precedent for the way governments select companies to support. Although Norway's actions are liberal and progressive, corrupt relationships between companies and countries rich with natural resources will continue to plague international society. Although this is a complex issue to resolve, there are several ways to combat this problem and end the conflict between the laws of the home and the host countries. One proposal is to have the United States monitor its companies operations abroad more effectively, to ensure that they are abiding by United States legislation. This would be more of a guarantee that if a company were engaging in illegal activities, the United States would be capable of trying and punishing them appropriately. Depending on domestic regulation may be more effective in restricting transnational companies because in the past, international resolutions have not always been successful monitoring them.

However, this potential solution has several flaws, because it is already established that the United States does not have strict enough laws to monitor the companies operations abroad. In addition, if the United States is the sole country to pass an act concerning company's operations abroad, the problems of corruption, continued environmental degradation, and human rights abuses are not going to end; also, domestic policies will try to benefit the home country, and therefore may not be as stringent as necessary to protect the rights of the indigenous population of the host country or its environment. Therefore, a second idea, of establishing an international standard, may be the most effective means to solve this problem. Although international resolutions can be weak because regulation is difficult, companies may be less likely to defy or attempt to circumvent them for fear of their reputations or of the repercussions in international communities. Another method 
is simply to boycott the companies that continue to violate international standards, on an individual and government level, as exhibited by Norway; oil companies that do not adhere to the "best practices" (Karl 484), in terms of ethical standards will be boycotted. If the boycotts were sufficiently well organized, they might significantly deter misconduct by companies.

Freeport provides a striking example of a company that has utilized the discrepancies in the United Statesíand Indonesian legislation to its their advantage. It is the international communityís responsibility to punish these companies for their unjust actions. Failure to do so makes the international community complicit in the abuse or indigenous populations and the environment. The global community needs to create stricter legislation to prevent companies from turning mountains into billions of tons of waste. If the international community does not act, it invites a future in which we hasten iour own demise by destroying [our] natural resources and producing uncontrollable amounts of waste" (Reece 231). If we are able to develop ìa moral attitude toward the natural world, then ... we would recognize the natural world not merely as a resource, but as something much more profoundówhat Thoreau liked to call the Poem of Creation" (Reece 232), sparing humanity from oblivion.

\section{Works Cited}

Hills, Jonathan, and Richard Welford. "Case Study: Auditing for Human Rights: Freeport-McMoRan Copper and Gold in Papua." Wiley InterScience (2006): 108-114. Academic Search Premier. Stanford University, Stanford. 3 May 2007. Keyword: Freeport.

Johnson, Andrew, and Max Jarman. "Criticism Circles Indonesian Mine." The Arizona Republic 21 Nov. 2006, sec. D: 1. Global Newsbank. Stanford University, Stanford. 6 June 2007.

Karl, Terry L. The Political Challenge of Escaping the Resource Curse: the Case for a Transparent Fiscal Social Contract. Stanford University. Palo Alto: Stanford University. 465-494.

Landler, Mark. “Norway Backs Its Ethics with Its Cash.” The New York Times 4 May 2007: 1. Global Newsbank. Stanford University, Stanford. 6 June 2007. Leith, Denise. The Politics of Power. Honolulu: University of Hawaii, 2003.

Mealey, George A. Grasberg: Mining the Richest and Most Remote Deposit of Copper and Gold in the World, in the Mountains of Irian Jaya, Indonesia (New Orleans: Freeport-McMoRan Copper and Gold, 1996), p.71

McMillan, John. Promoting Transparency in Angola. Journal of Democracy. Johns Hopkins UP, 2005. 24 May 2007 <http://muse.jhu.edu/journals/journal_of_democracy/v016/16.3mcmillan.html>.

Mikesell, Raymond F. Foreign Investment in Mining Projects. Cambridge: Oelgeschlager, Gunn \& Hain, Inc.

Photo Courtesy of:

"Freeport McMoRan's Grasberg Mine operations destroy the Papua landscape." Amnesty International. 4 April 2009. <www.amnestyusa.org/justearth/indonesia.html>.

Photo Courtesy of:

"Suharto." 1 Jun. 1989. Associated Press. 4 Apr. 2009. <http://apimages.ap.org/OneUp.aspx?st=k\&kw=suharto\&showact=results\&sort=relevance

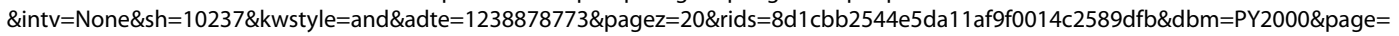
$1 \& \mathrm{xs} \mid \mathrm{t}=1$ \&dispname $=890601070 \% 2$ C $\% 20 I N D O N E S I A>$.

Photo Courtsey of:

Swaine, Emily."Mangrove from Southeast Asia and palm oil plantation." Association for Tropical Biology and Conservation. 4 April 2009. <www.atbc2008.org/news/20.htm>. 


\title{
Cornell International Affairs Review
}

$\begin{array}{ll}\text { Publications Associates } & \text { Editors } \\ \text { Junrong Koh } & \text { Alexandra Perrotti } \\ \text { Heidi Celeghin } & \text { Carolyn Witte } \\ \text { Bora Park } & \text { Becca Litman } \\ \text { Kristina Gabler } & \text { Leigh Korey } \\ \text { Finance Associates } & \text { Michael Jamison } \\ \text { Anna Collins } & \text { Ryan Woo } \\ \text { Sayako Seto } & \text { Heidi Celeghin } \\ \text { Global Networking } & \text { Junrong Koh } \\ \text { Alexander Frieden } & \text { Bora Park } \\ \text { Alyssa O' Connor } & \text { Rosie Lawrence } \\ \text { Bora Park } & \text { Zain Pasha } \\ \text { Dennis Shiraev } & \text { Luke Pryor } \\ \text { Donny Szirmak } & \text { Carrie Bronsther } \\ \text { Holly Mouton } & \text { Faraz Butte } \\ \text { James G. Rockas } & \text { James Rockas } \\ \text { Laura Fish } & \text { Rob Morrissey } \\ \text { Rob Morrissey } & \text { Israel Nares } \\ & \text { Sanjiv Tata }\end{array}$

\author{
Public Relations \\ Associates \\ Maurice Chammah \\ Alejandro Holguin \\ Arthur Neron-Bancel \\ Carolyn Witte
}

\section{Global Liaisons}

- Benjamin Barnier, Liaison Officer to McGill University, Canada

- Romain Jouvent, Liaison Officer to Sciences

Po, IEP de Paris, France

- Sohaib Perwaiz,

Liaison Officer to

Princeton University

- Haroon Ellahi Shaikh,

Liaison Officer to Pakistan

- Mitch Alva

Liaison Officer to Switzerland

\author{
Contributors \\ Institute for European Studies \\ The Mario Einaudi Center for International Studies \\ Student Assembly Finance Commission \\ Departement of Philosophy \\ The Lenquesaing Family \\ The Pedraza Family \\ Craig Yunker \\ Susan Kalus
}

\section{Submission Guidelines}

Please send submissions to President.CIAR@gmail.com or in hard copy at 401 Willard Straight Hall, Ithaca, NY 14850.

Submissions should be approximately 3000 words, but upon discussion with the editors, the limit may be reduced or expanded. Writers are encouraged to look at the articles published in previous issues to get acquainted with the style of CIAR. Submissions should be accompanied by a short biography of the author.

Articles that fit the criteria will be presented to the Editorial Board and reviewed. The Board will inform the author of its decision once their review process is over. The editing process then starts, with a series of back-and-forth between the assigned editor and the author. The Board reserves the right to make some minor changes before publication. 
The mission of the Cornell International Affairs Review is to act as a catalyst

to promote the understanding of international affairs among the Cornell community and other leading universities in the world.

The objective of the Cornell International Affairs Review is to promote an international, interdisciplinary and intergenerational approach to the analysis of world affairs. We believe that bringing together perspectives of students from different countries and majors, undergraduates and graduates, with the wisdom of professors and the vision of policy makers contributes in an original way to the debate on foreign policy.

The Cornell International Affairs Review aims to achieve its mission and objectives through the publication of a biannual review; the organization of lectures and panel discussions on campus; and the creation of a worldwide network of engaged students.

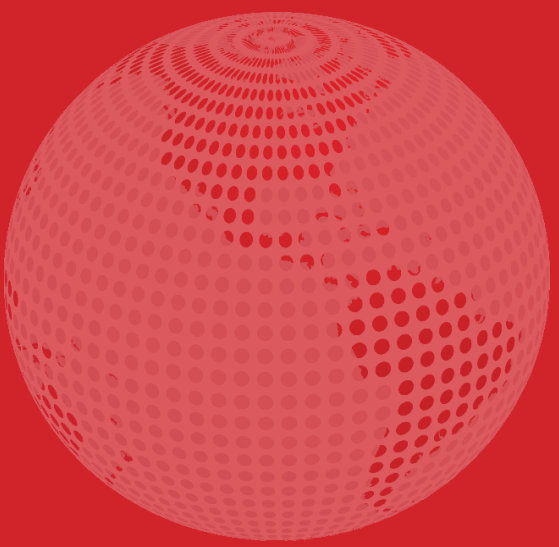

